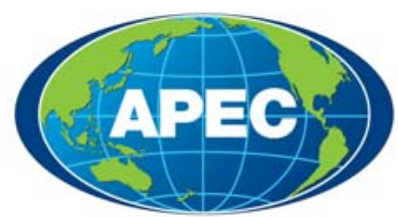

Asia-Pacific

Economic Cooperation

The Future of Liquid Biofuels for APEC Economies

\title{
Energy Working Group
}

May 2008 
Report prepared for the APEC Energy Working Group under EWG 01/2006A by:

Anelia Milbrandt

National Renewable Energy Laboratory (NREL)

Golden, Colorado, USA

Web site: www.nrel.gov

Dr. Ralph P. Overend

NREL Research Fellow (Retired)

Ottawa, Ontario, Canada

APEC\#208-RE-01.8 


\section{Acknowledgments}

The authors would like to acknowledge and thank the project overseer Mr. Rangsan Sarochawikasit (Department of Alternative Energy Development and Efficiency, Thailand) for his leadership of this project. We also would like to thank Dr. Helena Chum (National Renewable Energy Laboratory, USA) for contributing materials, and providing review and feedback; and the chair of APEC Biofuels Task Force, Mr. Jeffrey Skeer, (Department of Energy, USA) for his support and guidance.

The authors also greatly appreciate the time and valuable contributions of the following individuals:

Ms. Naomi Ashurst and Ms. Marie Taylor, Department of Industry, Tourism and Resources, Australia

Ms. Siti Hafsah, Office of the Minister of Energy, Brunei Darussalam

Mr. Mark Stumborg, Agriculture and Agri-Food, Canada

Ms. Corissa Petro, National Energy Commission, Chile

Mr. Song Yanqin and Mr. Zhao Yongqiang, National Development and Reform

Commission, China

Mr. K.C. Lo, Electrical and Mechanical Service Department, Hong Kong, China

Dr. Hom-Ti Lee, Industrial Technology Research Institute, Chinese Taipei

Mr. Hendi Kariawan, Indonesia Biofuels Team, Indonesia

Dr. Jeong-Hwan Bae, Korea Energy Economics Institute, Republic of Korea

Mr. Diego Arjona-Arguelles, Secretariat for Energy (SENER), Mexico

Mr. Angel Irazola and Mr. Diego de la Puente Consigliere, Agricola Del Chira S.A.,

Peru

Mr. Alex Ablaev, Russian National Biofuels Association, Russia

Ms. Judy Oberg, National Renewable Energy Laboratory (NREL), USA 


\section{Abbreviations and Acronyms}

APEC - Asia-Pacific Economic Cooperation

ASTM - American Society for Testing and Materials

CEH - Chemical Economics Handbook

CIS - Commonwealth of Independent States

CRP - conservation reserve program

CPO - Crude palm oil

DME - Dimethyl ether

ETBE - Ethyl tertiary butyl ether

EU - European Union

FAME - Fatty acid methyl esters

FAPRI - Food and Agricultural Policy Research Institute

FFV - Flexible fuel vehicles

FTL - Fischer Tropsch Liquids

Gasohol - E10 (blend of 10\% ethanol and 90\% gasoline)

GHG - Greenhouse gas

IMF - International Monetary Fund

ISO - International Organization for Standardization

LHV - Low heating value

LUC - land-use change (LUC)

MTBE - Methyl tertiary butyl ether

MSW - Municipal solid waste

NGOs - Non-Government Organizations

NREL - National Renewable Energy Laboratory (of the U.S. Department of Energy - DOE)

PNG - Papua New Guinea

R\&D - Research and development

RFS - renewable fuels standard

RFTO - renewable transport fuel obligation

RBD palm oil - Refined, bleached and deodorized

SVO - Straight vegetable oil

UNCTAD - United Nations Conference on Trade and Development

USD - U.S. dollar

USDA - U.S. Department of Agriculture 
USDOE - U.S. Department of Energy

\section{Units of Measure}

$\mathrm{hm}^{3}$ - Cubic hectometer $\left(1 \mathrm{hm}^{3}=10^{6} \mathrm{~m}^{3}=10^{9}\right.$ liter $)$

L - Liter

Tonne - Metric ton

GJ - Gigajoule

Gt - Gigatonne $\left(10^{15}\right)$ 


\section{Foreword}

This project was initiated by the Asia-Pacific Economic Cooperation (APEC) Energy Working Group (EWG), which is one of 11 APEC working groups. Its objective is to maximize the energy sector's contribution to the region's economic and social well-being through activities in five areas of strategic importance: energy supply and demand, energy and the environment, energy efficiency and conservation, new and renewable energy technologies, and liquid biofuels production and development.

This project was implemented by EGNRET (Expert Group on New and Renewable Energy Technologies), which was established by the EWG to promote and facilitate the expanded use of new and renewable energy, where it is cost-effective. The Expert Group is implementing a program of cooperation involving surveys, seminars, workshops, and projects such as this one on biofuels.

The project's primary objective is to analyze the state of biofuels in the APEC region and discuss factors affecting their further development. An overview of the status of biofuels in the APEC region is presented, as well as a brief summary for each of the 21 member economies. Topics include biofuels production, feedstock availability, economics, refueling infrastructure, use of alternative fuel vehicles, trade, and policies. Each of these topics could be a separate study, which would provide a more in-depth analysis. The intent here, however, is to capture the primary aspects of the status of biofuels in the APEC region, provide readers with an informational base as they analyze the subject further, and help identify the need for future work in the field.

It was not possible to make concrete projections, as the biofuels industry in the region is in its early stages and surrounded by uncertainties. While many economies share some issues related to biofuels, each has its own bioenergy concerns that need to be analyzed in detail. This would require a significant effort and a lot more information than was available for this project. With all that in mind, the study provides a discussion of the factors that influence the future evolution of liquid biofuels in the APEC economies and leaves further analysis and debate to its readers. 
The information provided in this publication has been obtained from various sources, which the authors believe to be reliable. These include personal communication with authorities in APEC member economies, publicly available and proprietary publications, and media releases. The authors make no warranty as to the accuracy or completeness of the information in this publication. We encourage readers to contact us with feedback and recommendations. 


\section{Summary}

Continued growth in the demand for transportation fuels and declining oil production within the APEC region have led member economies to consider alternative energy options, such as fuels made from biomass materials. In addition to energy security, other key drivers include improving air quality, tackling climate change, and revitalizing rural development. However, these drivers have different weights among the APEC members.

The biofuels industry in the APEC region consists of two distinct sectors, ethanol and biodiesel. Fuel ethanol production within the region in 2007 was estimated at approximately 27,600 million liters, mainly produced in the United States; China; Canada; Australia; and Thailand. Biodiesel production in 2007 was approximately 4,400 million liters with the United States; Indonesia; Malaysia; China; Australia; and Canada as leading producers.

Ethanol is made from starches and sugars, but advanced conversion technologies under development will allow it to be made from more abundant "cellulosic" biomass sources such as forest and agricultural residues. Economies such as the United States; China; and Japan are heavily investing in the development of this advanced technology. Biodiesel in the region is produced from vegetable oils, waste cooking oil, and animal fats. Some economies are considering alternative biodiesel feedstock such as jatropha and other nonedible oils. A longterm strategy pursued by few economies is the use of microalgae as a biodiesel feedstock; however, a considerable investment in R\&D is needed to make it a viable option.

Although biofuels trade is relatively minor within the APEC region, some member economies see substantial opportunities for export. These include Malaysia; Thailand; Indonesia; and the Philippines, which would greatly benefit from their proximity to China; Korea; and Japan - the latter economies are projected to be significant importers if the biofuels industry develops in the region.

While governments in some economies have provided substantial support for biofuels development, enabling it to compete with conventional gasoline and diesel, others have just begun to consider policy measures. Some policy instruments applied in the region include mandatory blending, fuel tax exemptions, loan guarantees, reduced enterprise taxes and subsidies (direct and indirect) for biofuels production, and R\&D investments. 
Several factors influence the continued growth of the biofuels industry and the long-term market potential for biofuels in the APEC region and around the world; but the fundamental one is production economics. The future development of sustainable biofuels also depends on a balanced scorecard to evaluate the performance of biofuels against the metrics of energy security, greenhouse gas $(\mathrm{GHG})$ reduction, and the energy return on investment $(\mathrm{EROI})$. For both first- and second-generation liquid biofuels, resolution of technical, economic, social, environmental, and regulatory issues remains critical to further development of biofuels in the APEC economies. 


\section{Table of Contents}

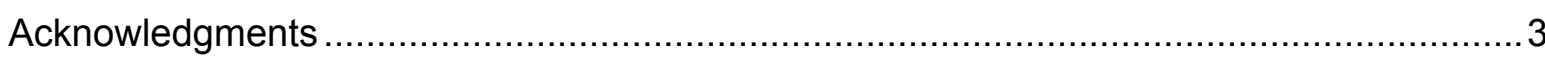

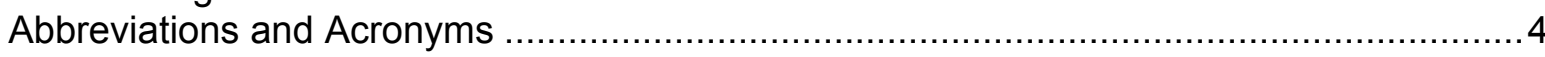

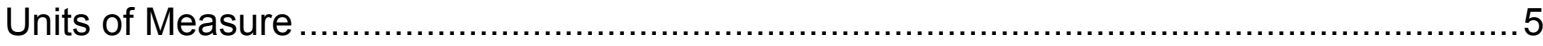

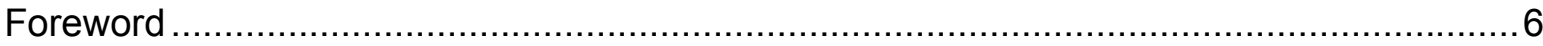

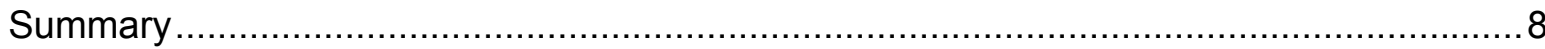

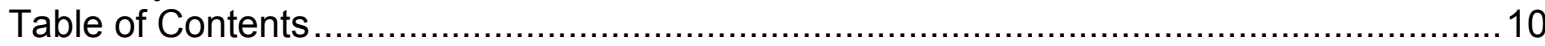

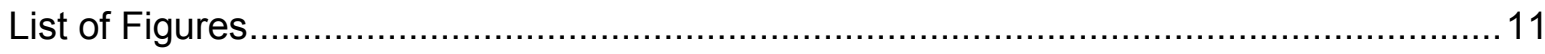

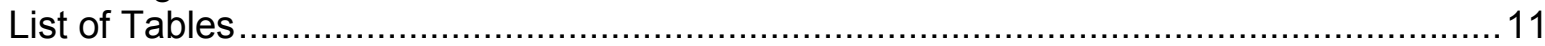

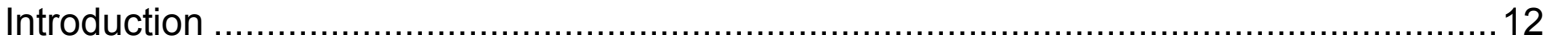

Current Status of Biofuels Development in the APEC Region .......................................17

Production.

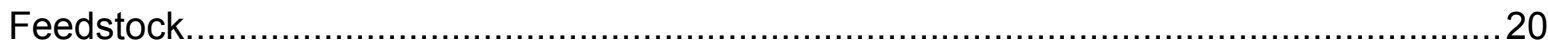

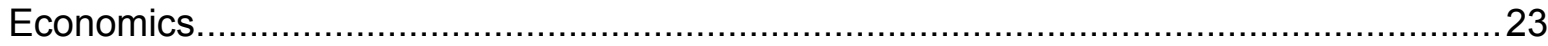

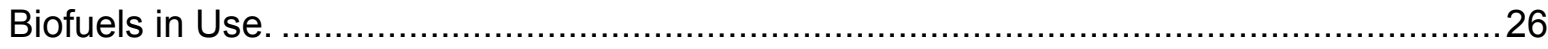

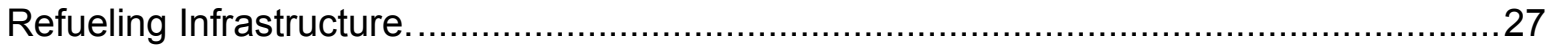

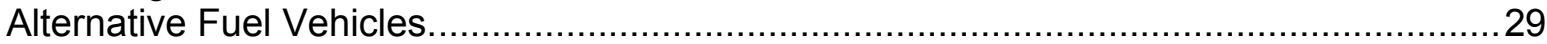

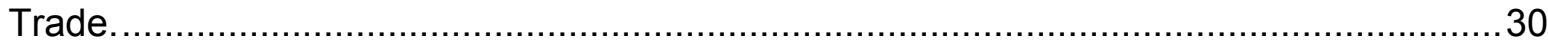

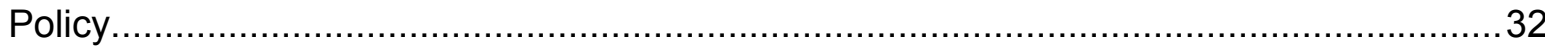

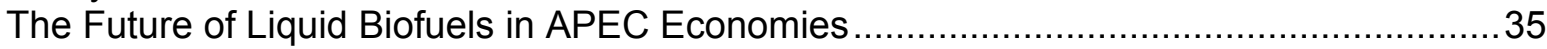

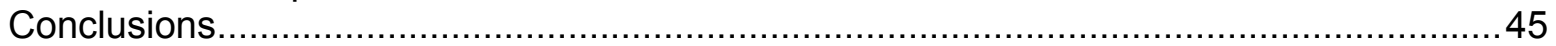

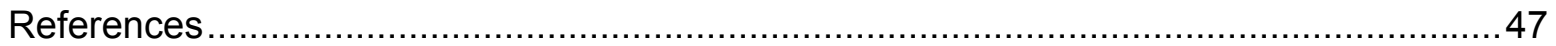

Appendix A: Current Status of Biofuels Development in the APEC Region by Member



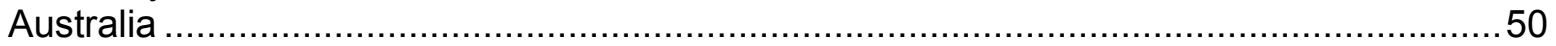



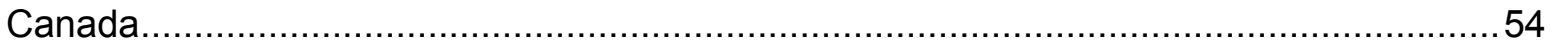



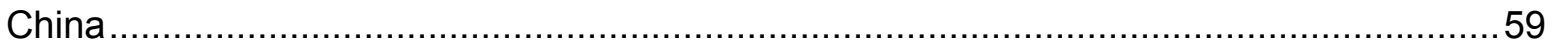

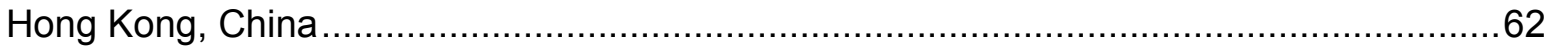

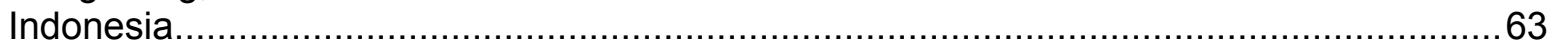

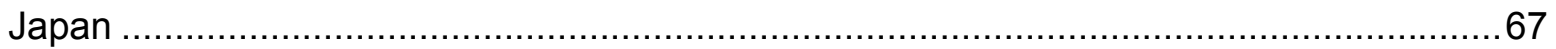

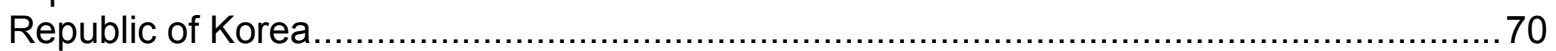

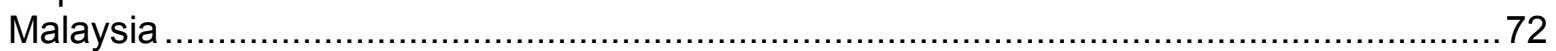

Mexico

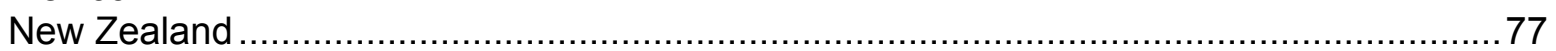

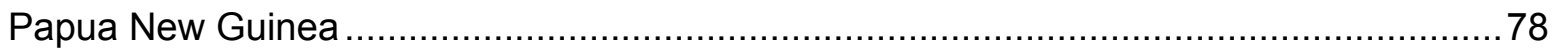

Peru

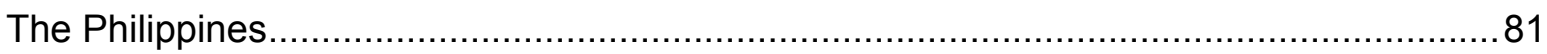

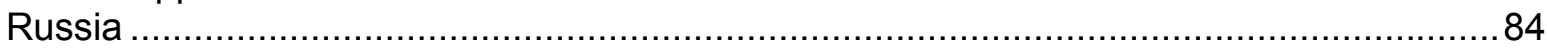

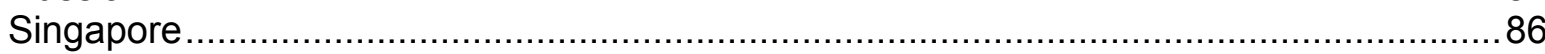

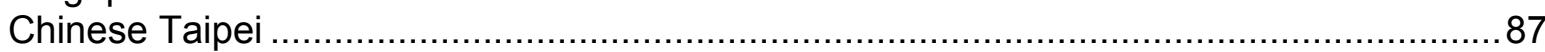

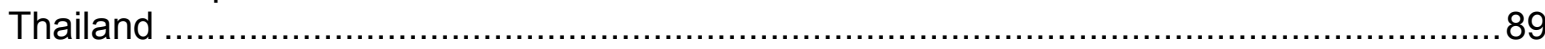

United States of America ................................................................................... 92

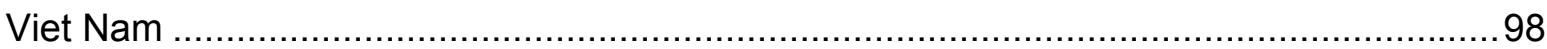

Appendix B: Projected Export of Major Oilseeds and Products by 2017/18 _..................100

Appendix C: Gasoline and Diesel Consumption in APEC Economies, 2005.................... 102 


\section{List of Figures}

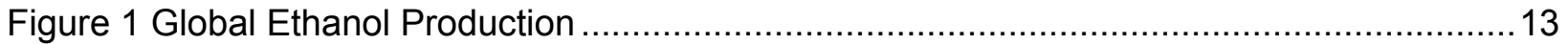

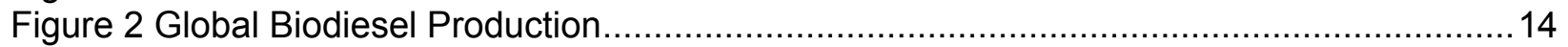

Figure 3 Price of Major Vegetable Oils ............................................................................ 19

Figure 4 Installed Biofuels Production Capacity in APEC Economies, 2006-2007 ..................20

Figure 5 Ethanol Feedstock in APEC Economies....................................................... 21

Figure 6 Biodiesel Feedstock in APEC Economies ....................................................... 21

Figure 7 Average Ethanol Production per Hectare of Farmland Yield by Crop........................22

Figure 8 Average Biodiesel Production per Hectare of Farmland Yield by Crop ......................23

Figure 9 Illustrative Ethanol Production Costs .....................................................................24



Figure 11 Historical and Projected Cellulosic Ethanol Costs ..............................................26

Figure 12 United States E85 Refueling Stations............................................................ 28

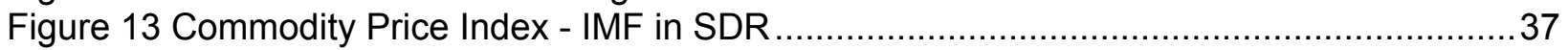

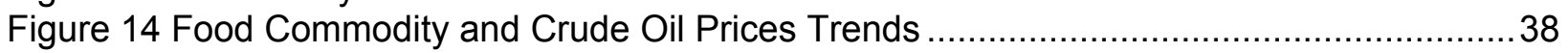

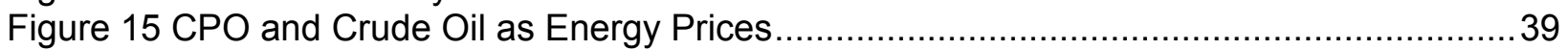

Figure 16 GHG Emissions Reduction Potential for Select Biofuels ....................................42

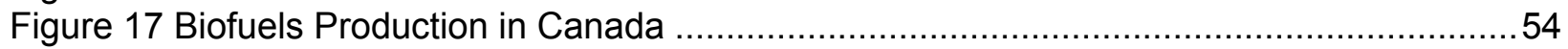

Figure 18 Ethanol Producers and Areas with E10 Consumption in China...............................59

Figure 19 Planned Ethanol Production Facilities in Indonesia ............................................63

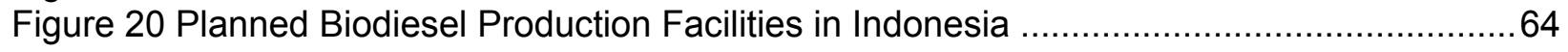

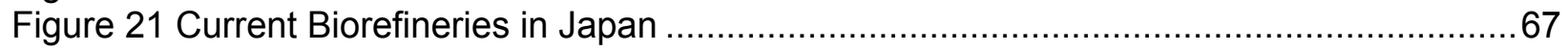

Figure 22 Proposed Fuel Ethanol Refineries and Sugarcane Producing Areas in Mexico.........74

Figure 23 Suitable Areas for Biodiesel Feedstock Production ............................................ 75

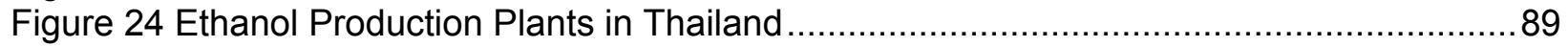

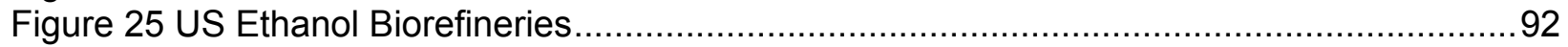





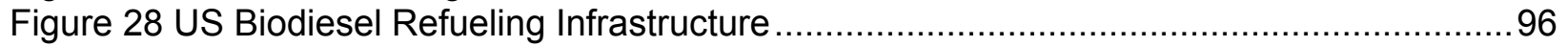

Figure 29 Projected Palm Oil Export by 2017/18 ........................................................... 100



Figure 31 Projected Soybean Oil Export by 2017/18 .................................................. 101

Figure 32 Projected Rapeseed Export by 2017/18 ...................................................... 101

Figure 33 Projected Rapeseed Oil Export by 2017/18 ................................................... 102

\section{List of Tables}

Table 1 Lower Heating Value (LHV) of various liquid transportation fuels.............................. 12

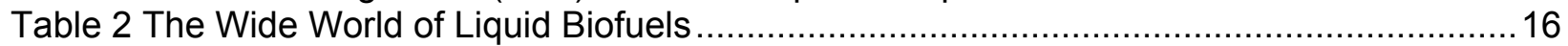

Table 3 Ethanol Production in APEC Economies ..................................................... 18

Table 4 Biodiesel Production in APEC Economies ...................................................... 18

Table 5 Biofuels Currently Used in the APEC Region .................................................2 27

Table 6 Cost of Adding E85 Equipment to Existing Gasoline Stations ..................................28

Table 7 Biofuel Mandates and Targets in APEC Economies .............................................. 34

Table 8 Estimated Change in Life Cycle GHG Emissions per km Travelled by Replacing

Gasoline with Various Ethanol Blends .........................................................................40

Table 9 Estimated Change in Life Cycle GHG Emissions per km Travelled by Replacing Diesel

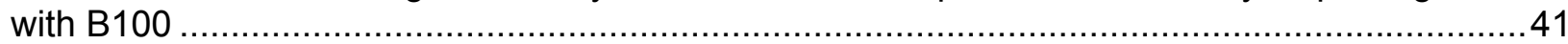

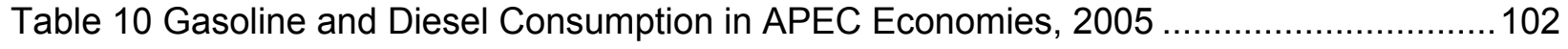




\section{Introduction}

The global production and use of biofuels have increased dramatically in the past few years, due to increasing oil prices, national security concerns, environmental considerations, and the urge to revitalize rural communities. The question today is no longer whether or not biofuels will be a part of the energy mix, but rather what are the economic, social, and environmental implications to their large-scale adoption.

Biofuels refer to transportation fuels derived from biomass material: conventional food crops (grains, oilseeds, and sugar crops), dedicated energy crops (grasses, shrubs, and trees), and agricultural residues and waste streams. While fossil fuels (petroleum, natural gas, and coal) consist entirely of hydrocarbons (carbon and hydrogen), current biofuels contain oxygen as well as carbon and hydrogen, which affects their physical and chemical properties during combustion. As a result, the biomass-derived oxygenates have a reduced heating value compared to hydrocarbons, thus releasing less energy than hydrocarbons during combustion. Table 1 compares the typical lower heating value (LHV) ${ }^{1}$ of several transportation fuels.

Table 1 Lower Heating Value (LHV) of various liquid transportation fuels

\begin{tabular}{|l|r|}
\hline Fuels & LHV(MJ/kg) \\
\hline Petroleum Diesel & 45 \\
\hline Fischer Tropsch (FT) Diesel & 44 \\
\hline Gasoline & 43 \\
\hline Biodiesel & 38 \\
\hline Butanol & 36 \\
\hline MTBE/ETBE & 35 \\
\hline Dimethyl ether (DME) & 29 \\
\hline Mixed Alcohols & 27 \\
\hline Ethanol & 27 \\
\hline Methanol & 20 \\
\hline Source: lowa State University &
\end{tabular}

Ethanol and biodiesel are the liquid biofuels most widely used for transport today. Ethanol $\left(\mathrm{C}_{2} \mathrm{H}_{5} \mathrm{OH}\right.$, ethyl alcohol $)$ is produced by the fermentation of carbohydrate materials. Today, ethanol is made from starches and sugars, but an advanced conversion technology allows it to be made from more abundant "lignocellulosic" biomass sources such as forest and agricultural

\footnotetext{
${ }^{1}$ The lower heating value of a fuel is the energy that can be recovered when the water of combustion is released as a vapor.

${ }^{2}$ MTBE (methyl tertiary butyl ether) is a liquid oxygenate produced from methanol and isobutylene, an oil refining product; ETBE (ethyl tertiary butyl ether) is a liquid oxygenate produced from ethanol
} 
residues. Ethanol is used for production of alcoholic beverages, for industrial purposes (as a solvent, disinfectant, or chemical feedstock), and in recent years, as a blending agent with gasoline to increase octane and reduce carbon monoxide and other smog-causing emissions. Low-level ethanol blends such as E10 (10\% ethanol and 90\% gasoline) can be used in conventional vehicles, while high-level blends, such as E85 (85\% ethanol and 15\% gasoline) can only be used in specially designed vehicles, such as flexible fuel vehicles (FFVs). Global ethanol production is estimated at a record 62,000 million liters in 2007 (Figure 1), with the United States and Brazil accounting for approximately $70 \%$ of the total output. Fuel ethanol accounted for about $77 \%$ of all ethanol consumed in 2006 , and it is likely that it reached $86 \%$ in 2007..$^{3}$

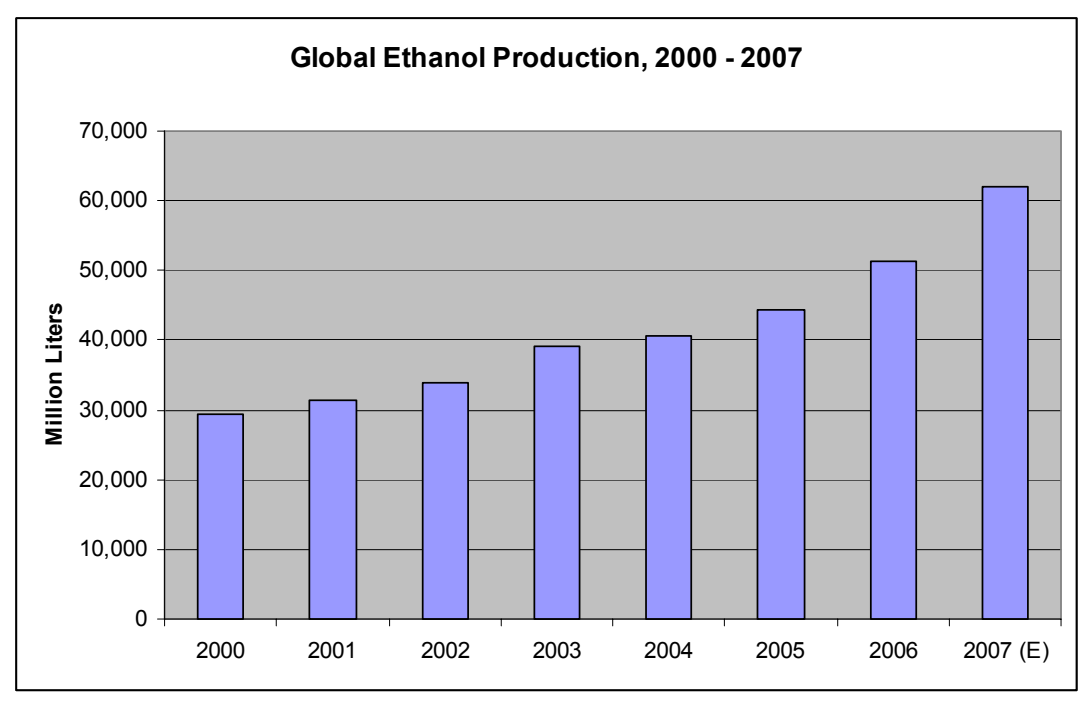

Source: F.O.Licht, 2007; E - estimate

Figure 1 Global Ethanol Production

Biodiesel is a liquid fuel made from vegetable oils and animal fats through a chemical process (transesterification) that reacts the feedstock with alcohol (usually methanol) to produce chemical compounds known as fatty acid methyl esters (FAME). Biodiesel is the name given to these esters when they meet specifications such as American Society for Testing and Materials (ASTM) D6751 or EN14214 for use as transportation fuel. Biodiesel is used in blends with petroleum diesel or in its pure form. B20 (20\% biodiesel and $80 \%$ diesel) and lower-level blends such as B2 (2\% biodiesel/98\% diesel) and B5 (5\% biodiesel/95\% diesel) can be used in any diesel engine. B100 (pure biodiesel) or other high-level biodiesel blends can be used in some engines built since 1994. Biodiesel is also used for space - and water heating in domestic and

\footnotetext{
${ }^{3}$ F.O. Licht, 2006; Worldwatch Institute, 2007
} 
commercial boilers. Global biodiesel production has been growing rapidly during the past few years, and estimates show that it may have reached 10,000 million liters in 2007 (Figure 2). Europe accounts for $73 \%$ of the total production, with Germany; France; Italy; and Czech Republic leading the way.

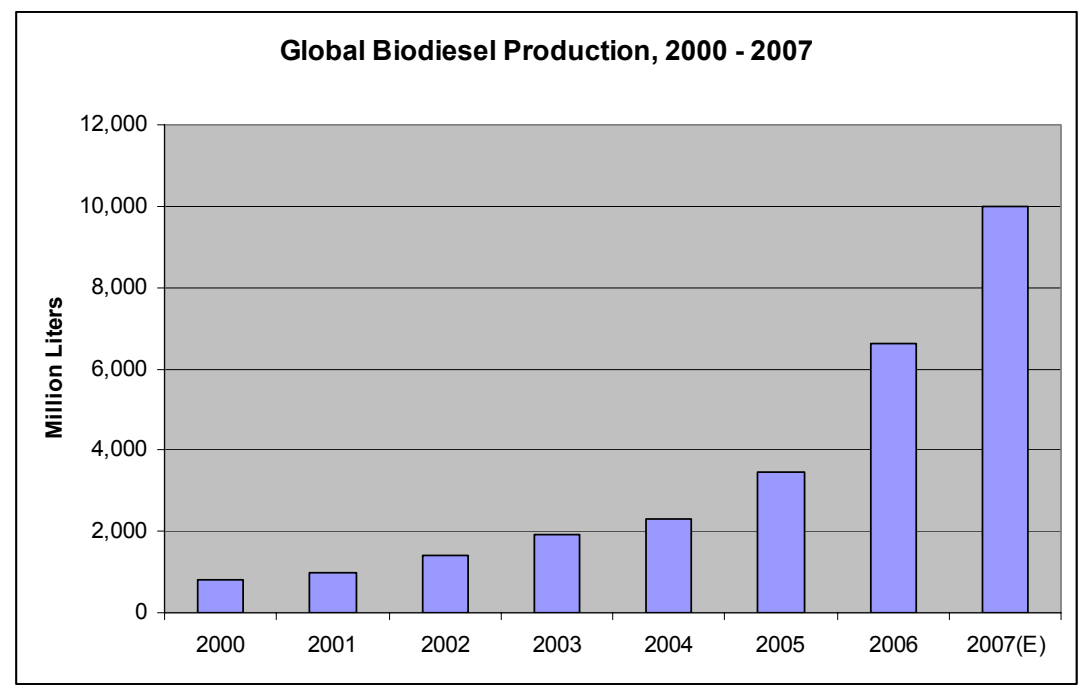

Source: F.O.Licht, 2008; E - estimate

Figure 2 Global Biodiesel Production

In addition to ethanol and biodiesel, there are other types of biomass-derived fuels under development (Table 2). Biofuels production from starches, sugars, and vegetable oils are wellestablished technologies, but sometimes are seen as competition with the food and feed industries. There are also environmental concerns, such as unregulated deforestation and heavier use of fertilizers; and ethanol from corn is controversial when it comes to the energybalance question (mitigated if biomass is used to supply heat and power). These and other issues are driving research for second-generation feedstock, new, or more efficient conversion processes and fuels. These technologies have the potential to substantially expand the feedstock base for biofuels production in the future (e.g., lignocellulosic biomass, nonedible vegetable oils, algae) and alleviate the food vs. fuel debate. However, none of the conversion processes using these feedstocks has reached the industrial stage. Although some of these processes (e.g., gasification of biomass followed by synthesis to liquid fuels) have been known for the past few decades, low petroleum prices have prevented their further development during that time. Increasing oil prices and energy security concerns have renewed the interest in biofuels in the past few years, thus reviving the R\&D in conversion technologies. 
As mentioned above, the advanced conversion technologies outlined in Table 2 are at different points in their development - experimental, in a demonstrational stage, or in a very early commercialization process. The production of "green" diesel via hydro-treatment is perhaps the closest to a commercialization stage. Brazil's state energy company Petrobras has adapted four refineries to produce $\mathrm{H}$-Bio diesel fuel using mineral and vegetable oil, but has not started mass production due to the high price of soy oil. Neste is constructing an 800 kilotonnes hydrogenated oil plant in Singapore (to be operational in 2010) using its NExBTL ${ }^{\mathrm{TM}}$ technology. The next technology in line for commercialization could be bio-ethanol production from lignocellulosic biomass via biochemical ${ }^{4}$ or thermo-chemical ${ }^{5}$ conversion process. logen Corporation has successfully produced bio-ethanol from wood waste via biochemical conversion in its pilot plant in Canada. In the United States, six commercial cellulosic ethanol plants are under construction - four of them will use biochemical-conversion technology and two will apply the thermo-chemical conversion process. China has several cellulosic ethanol pilot plants (using biochemical-conversion technology), and one exists in Japan. Australia is also building a pilot plant using this process. Within the next five years, more demonstration plants producing gasification-derived biofuels - such as Fischer Tropsh (FT) diesel, bio-methanol, and bioDimethyl Ether (DME) - are expected to come online. Biodiesel produced from algae is among the technologies to be developed in the future, perhaps within the next 5-10 years. Before the technology is commercially available, significant technical and economic barriers need to be overcome to finish the laboratory phase, test the process, and develop it sufficiently.

\footnotetext{
${ }^{4}$ Two key steps in biochemical conversion are biomass pretreatment and cellulose hydrolysis. During pretreatment, the hemicellulose part of the biomass is broken down into simple sugars and removed for fermentation. During cellulose hydrolysis, the cellulose part of the biomass is broken down into the simple sugar glucose.

${ }^{5}$ In thermo-chemical conversion, heat and chemicals are used to break biomass into syngas (a mixture of carbon monoxide and hydrogen) and reassemble it into products such as ethanol.
} 
Table 2 The Wide World of Liquid Biofuels

\begin{tabular}{|c|c|c|c|c|c|c|}
\hline Fuel Type & Feedstock & $\begin{array}{l}\text { Conversion } \\
\text { Technology }\end{array}$ & Description & Benefits & Issues/Challenges & Status \\
\hline Ethanol & \begin{tabular}{|l|} 
Current Technol \\
Grains / \\
Starches
\end{tabular} & $\begin{array}{l}\text { Enzymatic } \\
\text { fermentation }\end{array}$ & $\begin{array}{l}\text { Dry milling process - grains are ground into a } \\
\text { flour, and the starch is converted into sugar } \\
\text { with enzzymes and fermented to produce } \\
\text { ethang }\end{array}$ & $\begin{array}{l}\text { Mature technology - many facilities } \\
\text { already operational and in } \\
\text { construction. }\end{array}$ & \multirow{2}{*}{$\begin{array}{l}\text { Feedstock availability and production } \\
\text { is limited, and there is competition } \\
\text { with food products. Net energy } \\
\text { balance lower than projections for } \\
\text { cellulosic ethanol. }\end{array}$} & Commercial \\
\hline Ethanol & $\begin{array}{l}\text { Grains / } \\
\text { Starches }\end{array}$ & $\begin{array}{l}\text { Separation and } \\
\text { fermentation }\end{array}$ & $\begin{array}{l}\text { ethanol. } \\
\begin{array}{l}\text { Wet milling process - grain separated into } \\
\text { components and starch is yeast fermented and } \\
\text { distilled }\end{array} \\
\end{array}$ & $\begin{array}{l}\begin{array}{l}\text { Mature technology - many facilities } \\
\text { already operational and in } \\
\text { construction. }\end{array} \\
\end{array}$ & & Commercial \\
\hline Ethanol & Sugars & Fermentation & $\begin{array}{l}\text { Sugar crops (like sugarcane) are crushed to } \\
\text { extract the juice and fermented to produce } \\
\text { ethanol. }\end{array}$ & \begin{tabular}{|l|}
$\begin{array}{l}\text { Mature technology. More efficient } \\
\text { than conversion of starches. }\end{array}$ \\
\end{tabular} & $\begin{array}{l}\text { Limited feedstock availability in } \\
\text { temperate climates. }\end{array}$ & Commercial \\
\hline Biodiesel & $\begin{array}{l}\text { Vegetable oil } \\
\text { Animal fat } \\
\text { Grease }\end{array}$ & Transesterification & $\begin{array}{l}\text { The feedstock is reacted with alcohol (usually } \\
\text { methanol) in the presence of an alkaline } \\
\text { catalyst to produce chemical compounds } \\
\text { known as fatty acid methyl esters (FAME) }\end{array}$ & $\begin{array}{l}\text { Ease of conversion, biodiesel can } \\
\text { be used in diesel, ngines without } \\
\text { adjustments. Significant heating oil } \\
\text { market. }\end{array}$ & Cold climates technical issues. & Commercial \\
\hline \multirow[t]{2}{*}{$\begin{array}{l}\text { Straight } \\
\text { vegetable oil } \\
\text { (SVO) }\end{array}$} & $\begin{array}{l}\text { Vegetable oil } \\
\text { Animal fat } \\
\text { Grease }\end{array}$ & $\begin{array}{l}\text { Mechanical pressing } \\
\text { or solvent extraction }\end{array}$ & Filtering out particles and removing water & \begin{tabular}{|l|}
$\begin{array}{l}\text { Viable fuel for tropical regions } \\
\text { where saturated oils are available. } \\
\text { Coconut oil can be blended directly } \\
\text { with diesel and used in unmodified } \\
\text { engines in tropical regions. }\end{array}$ \\
\end{tabular} & \begin{tabular}{|l|}
$\begin{array}{l}\text { Not suitable for use in regular diesel } \\
\text { engines (except coconut oil and other }\end{array}$ \\
saturated oils).
\end{tabular} & $\begin{array}{l}\text { Commercial (The } \\
\text { Philippines, Papua } \\
\text { New Guinea, EU) }\end{array}$ \\
\hline & \multicolumn{2}{|c|}{\begin{tabular}{|l} 
Future Techno ogies \\
\end{tabular}} & & & & \\
\hline Green Diesel & $\begin{array}{l}\text { Vegetable oil } \\
\text { Animal fat } \\
\text { Grease }\end{array}$ & Hydroprocessing & $\begin{array}{l}\text { Biomass oils conversion to diesel and other } \\
\text { hydrocarbons via hydrotreating methods as } \\
\text { in petroleum refinery }\end{array}$ & $\begin{array}{l}\text { Low sulfur diesel. Capital and } \\
\text { operating costs could be } \\
\text { substantially lower than those for } \\
\text { transesterification. }\end{array}$ & Feedstock availability. & $\begin{array}{l}\text { Early stage of } \\
\text { commercialization in } \\
\text { Brazil by Petrobras; } \\
\text { NESTE in Finland is } \\
\text { constructing a plant } \\
\end{array}$ \\
\hline Bio-ethanol & $\begin{array}{l}\text { Lignocellulosic } \\
\text { biomass }\end{array}$ & $\begin{array}{l}\text { Enzymatic } \\
\text { hydrolysis and } \\
\text { fermentation }\end{array}$ & $\begin{array}{l}\begin{array}{l}\text { Hemicellulose and cellulose converted to } \\
\text { sugars via enzymatic hydrolysis. Various } \\
\text { options for hemicicllulose conversion } \\
\text { (pretreatment). Sugars converted to alcohol via } \\
\text { fermentation. }\end{array}\end{array}$ & \begin{tabular}{|l|} 
Relatively low maintinance costs. \\
Potentially very high glucose yield.
\end{tabular} & \begin{tabular}{|l|} 
Cellulase costs must be reduced. \\
Enzymes are sensitive to poisoning.
\end{tabular} & $\begin{array}{l}\text { Demonstrational plant } \\
\text { currently operating in } \\
\text { Canada; Four } \\
\text { commercial plants are } \\
\text { under construction in } \\
\text { the US; Several pilot } \\
\text { plants exist in China } \\
\text { and one in Japan; A } \\
\text { pilot plant is currently } \\
\text { under construction in } \\
\text { Australia }\end{array}$ \\
\hline Bio-ethanol & $\begin{array}{l}\text { Lignocellulosic } \\
\text { biomass }\end{array}$ & $\begin{array}{l}\text { Gasification and } \\
\text { fermentation }\end{array}$ & $\begin{array}{l}\text { Gasification to produce syngas (a gaseous } \\
\text { mixture rich in hydrogen and carbon } \\
\text { monoxide), which is then conditioned and } \\
\text { compressed. The compressed gas is } \\
\text { fermented to ethanol. }\end{array}$ & $\begin{array}{l}\text { Higher yield of ethanol per ton of } \\
\text { feedstock than direct fermentation } \\
\text { of biomass. Feedstock flexibility. }\end{array}$ & \begin{tabular}{|l|} 
Gasification requires dried biomass. \\
High level of syngas clean-up \\
required.
\end{tabular} & $\begin{array}{l}\text { Two commercial plants } \\
\text { (Range Fuels and } \\
\text { Alico) are under } \\
\text { construction in the US }\end{array}$ \\
\hline $\begin{array}{l}\text { Fischer } \\
\text { Tropsh (FT) } \\
\text { Diesel }\end{array}$ & \begin{tabular}{|l} 
Lignocellulosic \\
biomass
\end{tabular} & $\begin{array}{l}\text { Gasification and FT } \\
\text { synthesis }\end{array}$ & $\begin{array}{l}\text { Gasification to produce syngas, which is then } \\
\text { cleaned and purfied. The clean syngas then } \\
\text { undergoeses a catalytyic processs to snythesize } \\
\text { hydrocarbons and their oxygen derivatives by } \\
\text { the controlled reaction of hydrogen and carbon } \\
\text { monoxide. The product is separated and } \\
\text { upgraded. }\end{array}$ & $\begin{array}{l}\text { FT diesel can substitute directly } \\
\text { conventional diesel with lower } \\
\text { emissions. Feedstock flexibility. }\end{array}$ & \begin{tabular}{|l|} 
Gasification requires dried biomass. \\
High level of syngas clean-up \\
required. Catalysts sensitive to \\
poisoning and sintering. Requires \\
improved yields.
\end{tabular} & $\begin{array}{l}\text { Demonstrational } \\
\text { facilities under way in } \\
\text { Germany, Austria, } \\
\text { Finland. }\end{array}$ \\
\hline $\begin{array}{l}\text { Mixed } \\
\text { Alcohols }\end{array}$ & $\begin{array}{l}\text { Lignocellulosic } \\
\text { biomass }\end{array}$ & $\begin{array}{l}\text { Gasification and } \\
\text { thermochemical } \\
\text { conversion }\end{array}$ & $\begin{array}{l}\text { Syngas production via biomass gasification, } \\
\text { followed by catalytic conversion to a mixture of } \\
\text { products (organic acids, ketones, and } \\
\text { alcohols). }\end{array}$ & \begin{tabular}{|l|} 
Mixed alcohols have higher energy \\
content than ethanol. When \\
blending, the higher alcohols \\
lincrease compatibility of gasoline \\
and ethanol, which increases \\
water tolerance and decreases \\
evaporative emissions. Higher \\
alcohols also perform better in cold \\
climates. Feedstock flexibility.
\end{tabular} & $\begin{array}{l}\text { Gasification requires dried biomass. } \\
\text { High level of syngas clean-up } \\
\text { required. Catalysts sensitiviv to } \\
\text { deactivation from sintering. Process } \\
\text { requires inmproved yeilds. Potential } \\
\text { groundwater contamination from } \\
\text { mixed alcohols usage. }\end{array}$ & $\begin{array}{l}\text { Demonstrational } \\
\text { facilities planned for } \\
\text { operation within } 5 \\
\text { years. }\end{array}$ \\
\hline Bio-butanol & \begin{tabular}{|l|} 
Starches, \\
Sugars, \\
Lignocellulosic \\
biomass
\end{tabular} & $\begin{array}{l}\text { Traditional ABE } \\
\text { fermentation }\end{array}$ & $\begin{array}{l}\text { The anaerobic conversion of carbohydrates by } \\
\text { strains of Clostridium into acetone, butanol and } \\
\text { ethanol. }\end{array}$ & $\begin{array}{l}\text { It can improve the blending of } \\
\text { ethanol with gasoline. It can be } \\
\text { transported in existing gasoline } \\
\text { pinelines and produces more } \\
\text { power than ethanol. }\end{array}$ & High cost, low yield & \begin{tabular}{|l} 
DuPont and $\mathrm{BP}$ are \\
setting up a pilot plant
\end{tabular} \\
\hline \begin{tabular}{|l} 
Pyrolysis \\
Liquids \\
(Bio-oil)
\end{tabular} & $\begin{array}{l}\text { Lignocellulosic } \\
\text { biomass }\end{array}$ & Pyrolysis & $\begin{array}{l}\text { Biomass conversion to bio-oil via fast pyrolysis - } \\
\text { heating biomass in restricted contact with air. } \\
\text { Vapours emitted from the reactor are collected } \\
\text { and cooled to vield aliquid, called bio-oil. } \\
\text { Opportunity for co-processing with fossil fuels in } \\
\text { petroleum refinery. }\end{array}$ & $\begin{array}{l}\text { Using refinery technologies } \\
\text { already in place, ease of adoption } \\
\text { into current infrastructure }\end{array}$ & \begin{tabular}{|l|} 
In early development stages. Refinery \\
integration issues.
\end{tabular} & $\begin{array}{l}\text { Small scale } \\
\text { demonstration facilities } \\
\text { are under way in } \\
\text { Canada, the US, the } \\
\text { Netherlands }\end{array}$ \\
\hline \begin{tabular}{|l} 
Renewable \\
Diesel
\end{tabular} & $\begin{array}{l}\text { Vegetable oil } \\
\text { Animal fat } \\
\text { Grease }\end{array}$ & $\begin{array}{l}\text { Hydrothermal } \\
\text { processing }\end{array}$ & $\begin{array}{l}\text { Biomass is reacted in water at an elevated } \\
\text { temperature and pressure to form oils and } \\
\text { residual solids. }\end{array}$ & Low sulfur diesel. & Feedstock availability. & \begin{tabular}{|l|} 
Demonstrational pilot \\
plant in the US \\
by Changing World \\
Technologies (CWT). \\
\end{tabular} \\
\hline Bio-methanol & $\begin{array}{l}\text { Lignocellulosic } \\
\text { biomass }\end{array}$ & $\begin{array}{l}\text { Gasification and } \\
\text { Synthesis } \\
\text { (with catalyst) }\end{array}$ & $\begin{array}{l}\text { Biomass is gasified first to produce a syngas } \\
\text { from which the bio-methanol is produced }\end{array}$ & $\begin{array}{l}\text { Biomethanol can be blended with } \\
\text { petrol up to } 10-20 \% \text { without any } \\
\text { infrastructure changes. }\end{array}$ & $\begin{array}{l}\text { Low vapor pressure and energy } \\
\text { density. Safety measures need to be } \\
\text { considered (methanol is poisonous) }\end{array}$ & $\begin{array}{l}\text { Pillot plants under } \\
\text { development in } \\
\text { Germany; R\&D in } \\
\text { China }\end{array}$ \\
\hline $\begin{array}{l}\text { Bio-DME } \\
\text { (Dimethyl } \\
\text { Ether) }\end{array}$ & $\begin{array}{l}\text { Lignocellulosic } \\
\text { biomass }\end{array}$ & $\begin{array}{l}\text { Gasification and } \\
\text { DME-synthesis }\end{array}$ & $\begin{array}{l}\text { Bio-DME is produced from syngas by means of } \\
\text { oxygenate synthesis. }\end{array}$ & $\begin{array}{l}\text { Bio-DME can be used as a fuel in } \\
\text { diesel engines; the process is } \\
\text { highly efficient and permits a large } \\
\text { scale production. It doesn't corrode } \\
\text { metals. }\end{array}$ & \begin{tabular}{|l|}
$\begin{array}{l}\text { Bio-DME can't be blended with fossil } \\
\text { diesel and it has a low energy content } \\
\text { (half that of diesel). Can affect certain } \\
\text { plastics and rubbers. }\end{array}$ \\
\end{tabular} & $\begin{array}{l}\text { Pilot plants under } \\
\text { development in } \\
\text { Sweden; R\&D in China }\end{array}$ \\
\hline $\begin{array}{l}\text { Biodiesel } \\
\text { Green Diesel }\end{array}$ & Algae & $\begin{array}{l}\text { Transesterification } \\
\text { or catalytic } \\
\text { hydroprocessing }\end{array}$ & $\begin{array}{l}\text { Lipids are derived from microalgae and } \\
\text { biodiesel is produced using conventional } \\
\text { transesterification technology. Alternatively, the } \\
\text { oils can be used to produce "green" diesel via } \\
\text { catalytic hydroprocessing. }\end{array}$ & $\begin{array}{l}\text { High yield per acre; could be used } \\
\text { for cO2 capture and reuse. }\end{array}$ & High cost & $\begin{array}{l}\text { R\&D programs in the } \\
\text { US, Japan, New } \\
\text { Zealand, South Africa, } \\
\text { and Western Europe } \\
\end{array}$ \\
\hline \begin{tabular}{|l|} 
HTU (Hydro- \\
Thermal \\
Upgrading) \\
Diesel
\end{tabular} & \begin{tabular}{|l} 
Lignocellulosic \\
biomass (wet)
\end{tabular} & $\begin{array}{l}\text { Catalytical hydro -de- } \\
\text { oxigenation (HDO) }\end{array}$ & $\begin{array}{l}\text { Biomass is converted to a heavy liquid at a high } \\
\text { temperature and pressure, then the well } \\
\text { established refinery technology HDO is applied. }\end{array}$ & $\begin{array}{l}\text { It can be mixed with fossil diesel in } \\
\text { any percentage without the need } \\
\text { for engine or infrastructure } \\
\text { changes. }\end{array}$ & Under experiment & $\begin{array}{l}\text { Royal Dutch Shell is } \\
\text { experimenting with the } \\
\text { process }\end{array}$ \\
\hline $\begin{array}{l}\text { Mixed } \\
\text { Alcohols }\end{array}$ & $\begin{array}{l}\text { Lignocellulosic } \\
\text { biomass }\end{array}$ & $\begin{array}{l}\text { Anaerobic digestion } \\
\text { and hydrogenation }\end{array}$ & $\begin{array}{l}\text { Anaerobic digestion of biomass with } \\
\text { methanogenic inhibition followed by } \\
\text { evaporation and fermentation. Produces a } \\
\text { mixture of products (organic acids, ketones, } \\
\text { and alcohols). }\end{array}$ & \begin{tabular}{|l|} 
Mixed alcohols have higher energy \\
content than ethanol. When \\
blending, the higher alcohols \\
increase compatibility of gasoline \\
and ethanol, which increases \\
water tolerance and decreases \\
evaporative emissions. Higher \\
alcohols also perform better in cold \\
climates. Feedstock flexibility.
\end{tabular} & $\begin{array}{l}\text { No commercial partners at this time. } \\
\text { Potential groundwater contamination } \\
\text { from mixed alcohols usage. }\end{array}$ & \begin{tabular}{|l|} 
Laboratory scale \\
research in academic \\
laboratories
\end{tabular} \\
\hline
\end{tabular}

Source: U.S. National Renewable Energy Laboratory; Antares Group Inc. 


\section{Current Status of Biofuels Development in the APEC Region}

APEC's 21 Member Economies include Australia; Brunei Darussalam; Canada; Chile; People's Republic of China; Hong Kong, China; Indonesia; Japan; Republic of Korea; Malaysia; Mexico; New Zealand; Papua New Guinea; Peru; The Republic of the Philippines; The Russian Federation; Singapore; Chinese Taipei; Thailand; United States of America; and Viet Nam. Together, these economies account for approximately $41 \%$ of the world's population, $56 \%$ of world GDP and $49 \%$ of world trade.

Accounting for about $60 \%$ of world energy demand, the APEC region is a net energy importer with its annual consumption exceeding domestic production. Energy imports to APEC economies are projected to increase by approximately $92 \%$ between 2000 and 2020 driven by economic growth, industrialization, and urbanization. According to the Asia-Pacific Energy Research Center, APEC's transport energy demand will almost double from 2002 to 2030, and the transport sector is expected to account for more than $70 \%$ of APEC's incremental oildemand growth (APEC Secretariat 2007). Given the steady growth in the demand for transportation fuels and declining oil production within the region, the APEC economies are experiencing a great concern over supply and are looking for alternative options. APEC members have identified biofuels as one option for a progressive transition to renewable sources of energy.

The biofuels industry in the APEC region consists of two distinct sectors, ethanol and biodiesel. Biofuels received a lot of attention from the public, academia, industry, and government in 2006 and 2007, making it an important time for biofuels development in the region. During this period, many goals and targets were announced, pilot projects began, and capacity expansion commenced. This chapter is an overview of the status of biofuels activities in the region during this time frame.

Production. The APEC region accounted for about $40 \%$ of the world fuel ethanol production in 2006, reaching 20,600 million liters - the majority (90\%) was supplied by the United States (Table 3 ). In 2007 , it is estimated that this increased by $40 \%$ to approximately 27,600 million liters of fuel ethanol. This was due to a production increase in economies such as the United States; China; Canada; Australia; Thailand; and Indonesia. During the 2008-2009 time frame, 
Table 3 Ethanol Production in APEC Economies

\begin{tabular}{|c|c|c|c|}
\hline Economy & 2006 Fuel Ethanol & 2006 Ethanol (all grades)* & 2007 Fuel Ethanol (E) \\
\hline Australia & 84 & 149 & 250 \\
\hline Brunei Darussalam & 0 & 0 & 0 \\
\hline Canada & 455 & 569 & 800 \\
\hline Chile & 0 & $\mathrm{~N} / \mathrm{A}$ & 0 \\
\hline China & 1,300 & 3,550 & 1,600 \\
\hline Hong Kong, China & 0 & $\mathrm{~N} / \mathrm{A}$ & 0 \\
\hline Indonesia & 82 & 170 & 140 \\
\hline Japan & 0.03 & 134 & $\mathrm{~N} / \mathrm{A}$ \\
\hline Korea & 0 & 160 & 0 \\
\hline Malaysia & 0 & $\mathrm{~N} / \mathrm{A}$ & 0 \\
\hline Mexico & 0 & 50 & 0 \\
\hline New Zealand & 0 & 15 & 0 \\
\hline Papua New Guinea & 0 & $\mathrm{~N} / \mathrm{A}$ & $\mathrm{N} / \mathrm{A}$ \\
\hline Peru & 0 & 16 & 0 \\
\hline The Philippines & 0 & 84 & 0 \\
\hline Russia & 0 & 560 & 0 \\
\hline Singapore & 0 & 30 & 0 \\
\hline Chinese Taipei & 0 & 10 & 0 \\
\hline Thailand & 130 & 383 & 200 \\
\hline United States & 18,550 & 21,000 & 24,600 \\
\hline Viet Nam & 0 & 80 & 0 \\
\hline APEC Total & 20,601 & 26,960 & 27,590 \\
\hline
\end{tabular}

Production in million liters; * Fuel, industrial and potable; N/A - Information not available; E - Estimate Sources: SRI Consulting, 2008; F.O. Licht 2007; DRET Australia; DEDE Thailand; NDRC China

Table 4 Biodiesel Production in APEC Economies

\begin{tabular}{|l|r|r|}
\hline Economy & 2006 Biodiesel & 2007 Biodiesel (E) \\
\hline Australia & 76 & 117 \\
\hline Brunei Darussalam & 0 & 0 \\
\hline Canada & 47 & 105 \\
\hline Chile & 0 & 0 \\
\hline China & 35 & 117 \\
\hline Hong Kong, China & 0 & 0 \\
\hline Indonesia & 590 & 1550 \\
\hline Japan & 3 & $\mathrm{~N} / \mathrm{A}$ \\
\hline Korea & 50 & 94 \\
\hline Malaysia & 141 & 217 \\
\hline Mexico & 15 & $\mathrm{~N} / \mathrm{A}$ \\
\hline New Zealand & $\mathrm{N} / \mathrm{A}$ & $\mathrm{N} / \mathrm{A}$ \\
\hline Papua New Guinea & $\mathrm{N} / \mathrm{A}$ & $\mathrm{N} / \mathrm{A}$ \\
\hline Peru & 27 & $\mathrm{~N} / \mathrm{A}$ \\
\hline The Philippines & 70 & 94 \\
\hline Russia & 0 & 0 \\
\hline Singapore & 23 & 35 \\
\hline Chinese Taipei & 2.4 & 3.8 \\
\hline Thailand & 35 & 58 \\
\hline United States & 882 & 2,000 \\
\hline Viet Nam & 0 & 0 \\
\hline APEC Total & 1,996 & 4,391 \\
\hline Productin matn
\end{tabular}

Production in million liters; E - Estimate; N/A - Information not available

Source: SRI Consulting, 2006; F.O. Licht 2008; DEDE Thailand; ITRI Chinese Taipei;

DRET Australia; NDRC China; KEEI Korea 
fuel ethanol plants are expected to come online in Peru; the Philippines; Chinese Taipei; and Viet Nam.

Biodiesel production in the APEC region was close to 2,000 million liters in 2006, supplying $32 \%$ of the global biodiesel production (Table 4). The major biodiesel producers in the region are the United States (44\%) and Indonesia (30\%). Biodiesel production in the region doubled in 2007 primarily due to increases in producing economies. It is expected that the region won't see a significant increase in biodiesel production in 2008. Indonesia and Malaysia, in particular, announced ambitious biodiesel goals in 2006 considering the availability of abundant feedstock (palm oil). However, increasing palm oil prices (vegetable oils, in general) during 2006-2007 (Figure 3) have altered producers' margins. Many existing biodiesel production plants run at low capacity, and some of those scheduled to come online in 2007 are on hold. Palm oil commodity price today sits above 1,000 USD tonne ${ }^{-1}$, a substantial climb from about 600 USD tonne ${ }^{-1}$ a year ago. Moreover, increasing vegetable oil prices have a negative effect on the biodiesel development in economies such as Korea and Singapore, which rely on imported feedstock. Although these economies expanded their production in 2007 , no significant growth is expected in 2008.

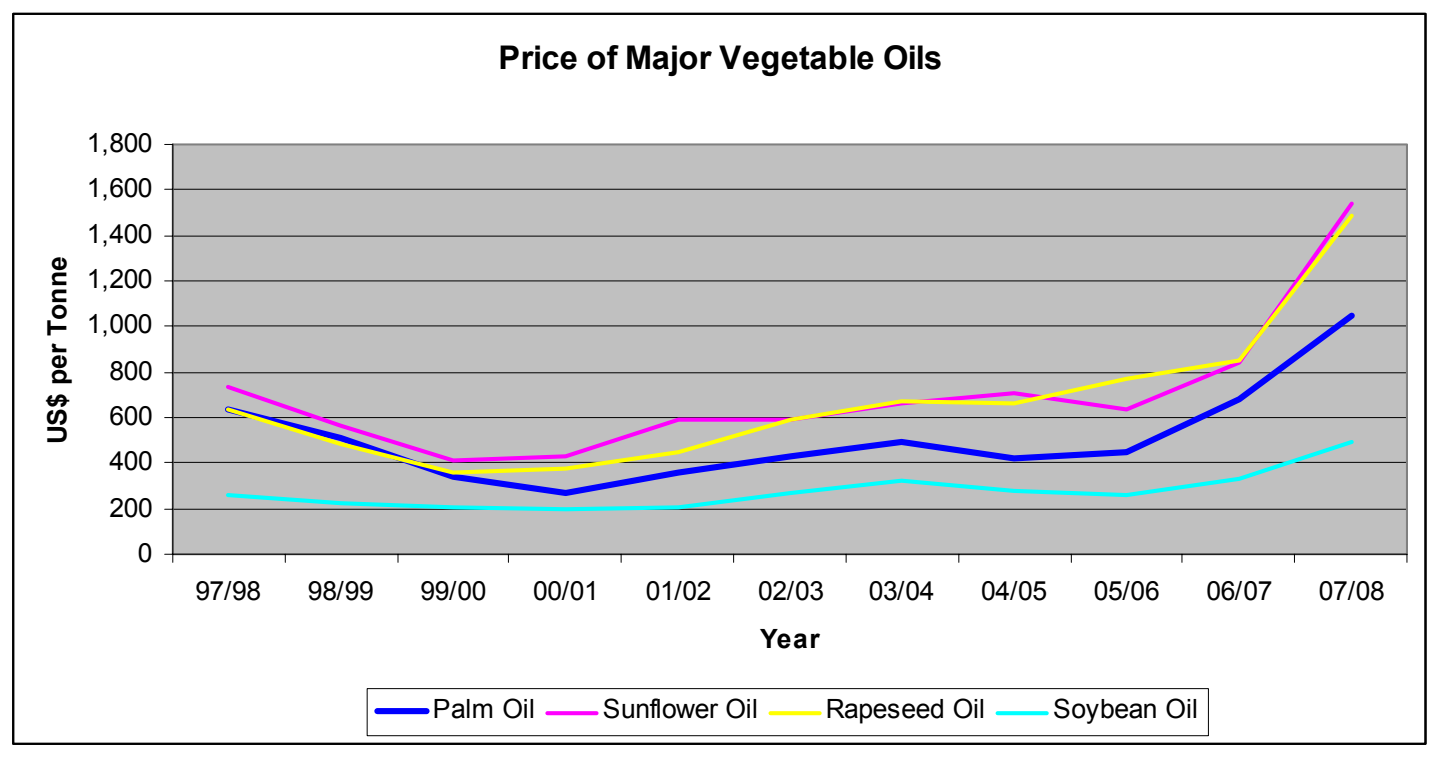

Source: FAPRI, April 2008

Figure 3 Price of Major Vegetable Oils

Installed biofuels production capacity in the APEC region was about 44,000 million liters in 2006-2007. Ethanol accounts for $71 \%$ of the total capacity, with the US industry contributing 
28,000 million liters (Figure 4). The United States is followed by China (1,800 million liters); Canada (715 million liters); and Thailand (435 million liters). Biodiesel production capacity installed in the region is about 12,000 million liters. The United States is a leading economy with 7,000 million liters, followed by Indonesia (2,000 million liters); Singapore (800 million liters); Thailand (655 million liters); and Korea (444 million liters). It is evident from Figure 4 that most of the APEC economies have invested in biodiesel production. For some (such as Indonesia and Malaysia), it is due to availability of feedstock and opportunities for biodiesel export; for others (such as Korea; Thailand; and the Philippines), it is predominately for domestic use considering their high petro-diesel consumption (Appendix C). Singapore, while also a dieseldriven economy, is trying to position itself as a major biofuel processing and trading hub in Asia.

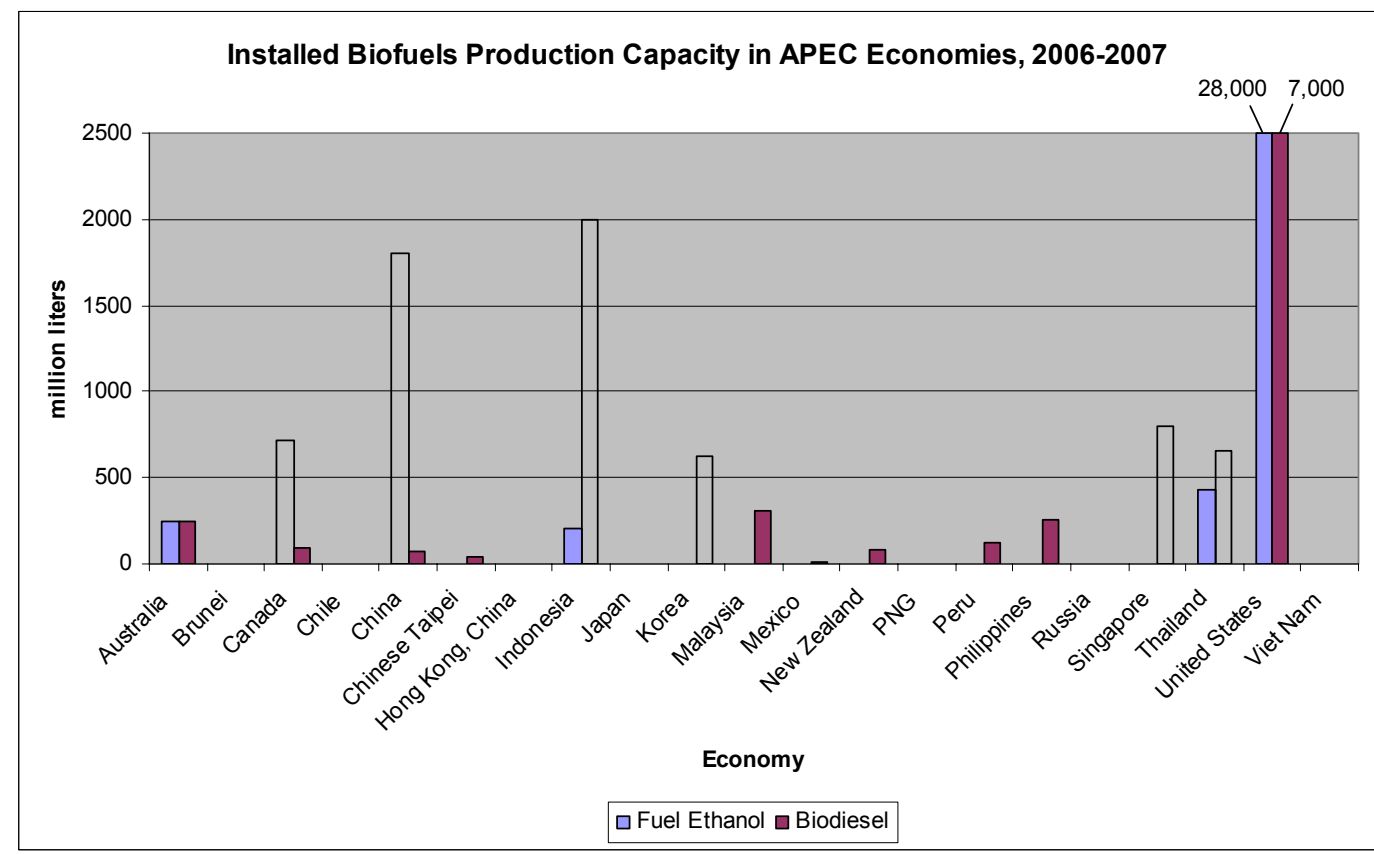

Source: Refer to Appendix A

Figure 4 Installed Biofuels Production Capacity in APEC Economies, 2006-2007

Feedstock. Biofuels in the APEC region are produced from a variety of first-generation feedstock using well-established conversion technologies. For ethanol production, these include: starches from grains (cereals, feed, and grains), tubers (cassava and sweet potatoes), sugars from crops (sugar beets, sugarcane, and sweet sorghum), and food-processing byproducts (molasses, cheese whey, and beverage waste). First-generation biodiesel feedstocks used in the APEC economies include vegetable oil (such as soybean, rapeseed, and palm oil), used cooking oil, and animal fat (tallow and cat fish oil). Second-generation feedstocks for ethanol production include lignocellulosic material, such as crop and forest 


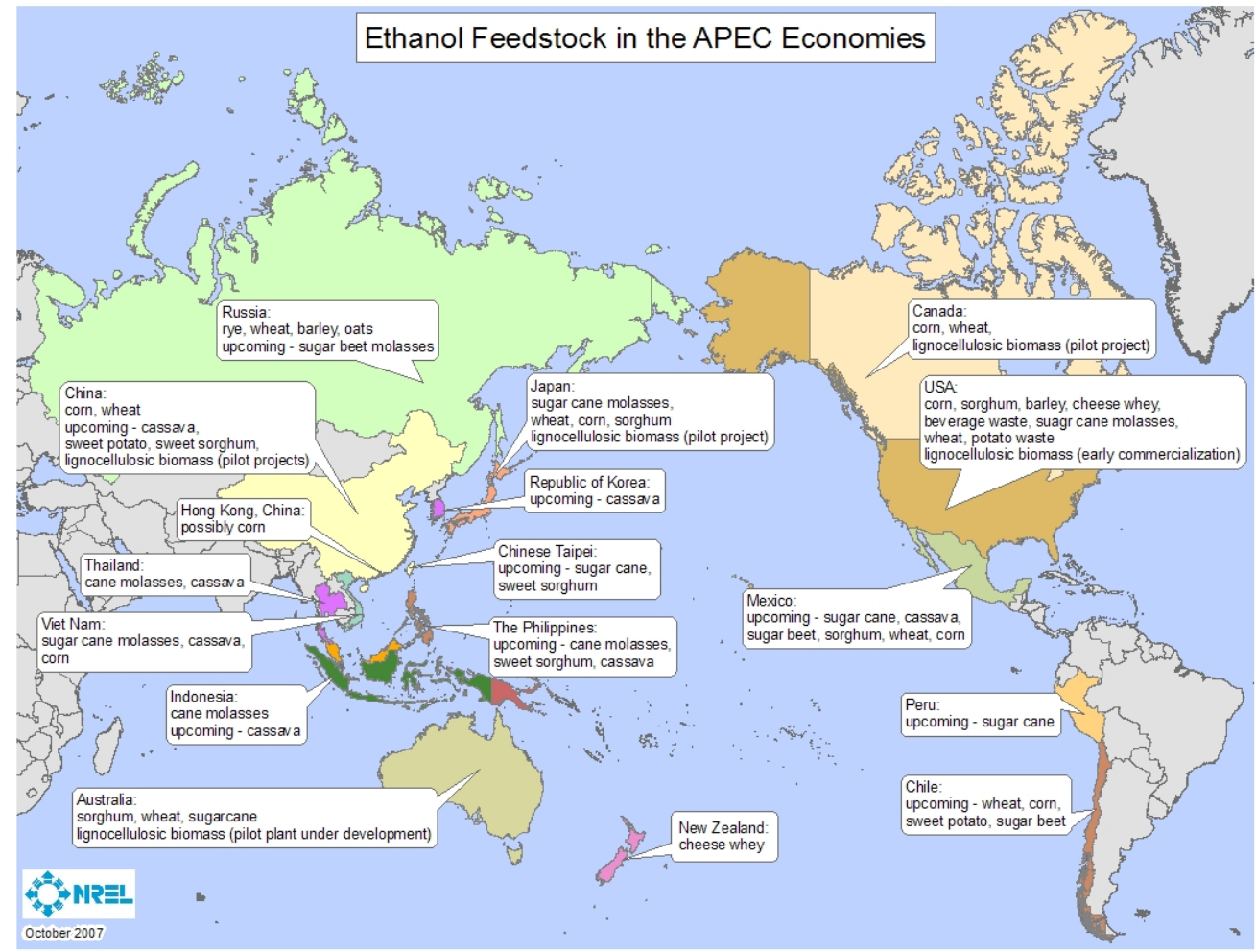

Figure 5 Ethanol Feedstock in APEC Economies

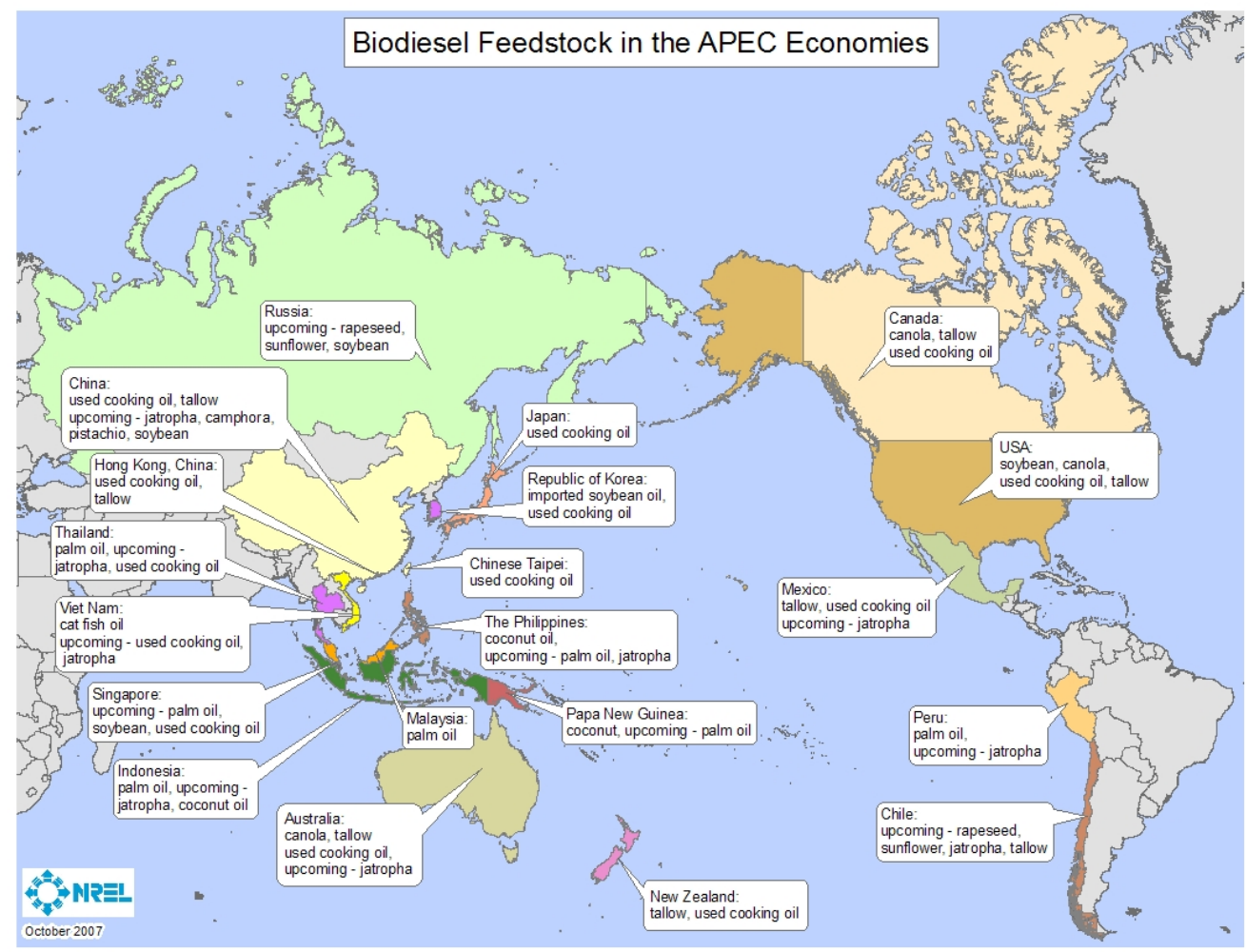

Figure 6 Biodiesel Feedstock in APEC Economies 
residues, urban residues (municipal solid waste - MSW), and dedicated energy crops (herbaceous and tree species). Economies with large-scale agriculture and forestry operations such as Canada; the United States; and China have set up demonstration projects using lignocellulosic biomass for ethanol production. An advanced biodiesel feedstock includes microalgae, and a few companies in the United States and New Zealand have started pilot projects to grow algae (Figures 5-6).

Yield efficiency per land unit for biofuels is an important consideration when choosing appropriate feedstock and making decisions for production expansion. APEC economies in the tropical biome have the advantage of growing crops with significant solar energy and rainfall input, yielding the highest biofuels per land unit compared with those in the temperate biome and its seasonal limitations. Tropical crops sugarcane and oil palm for biodiesel are the most desirable feedstocks for ethanol and biodiesel, respectively, considering their high yield per hectare (Figure 7 and Figure 8). China; Mexico; Thailand; Australia; and Indonesia are wellestablished sugarcane producers and among the top 10 suppliers in the world. Indonesia; Malaysia; and Thailand are the world's largest palm oil producers; the Philippines are the world's largest coconut oil producer; and Russia is the world's leader in sunflower oil production. Given the favorable climate conditions and significant labor availability, Southeast Asian economies have announced feedstock production expansion and large-scale biofuels programs.

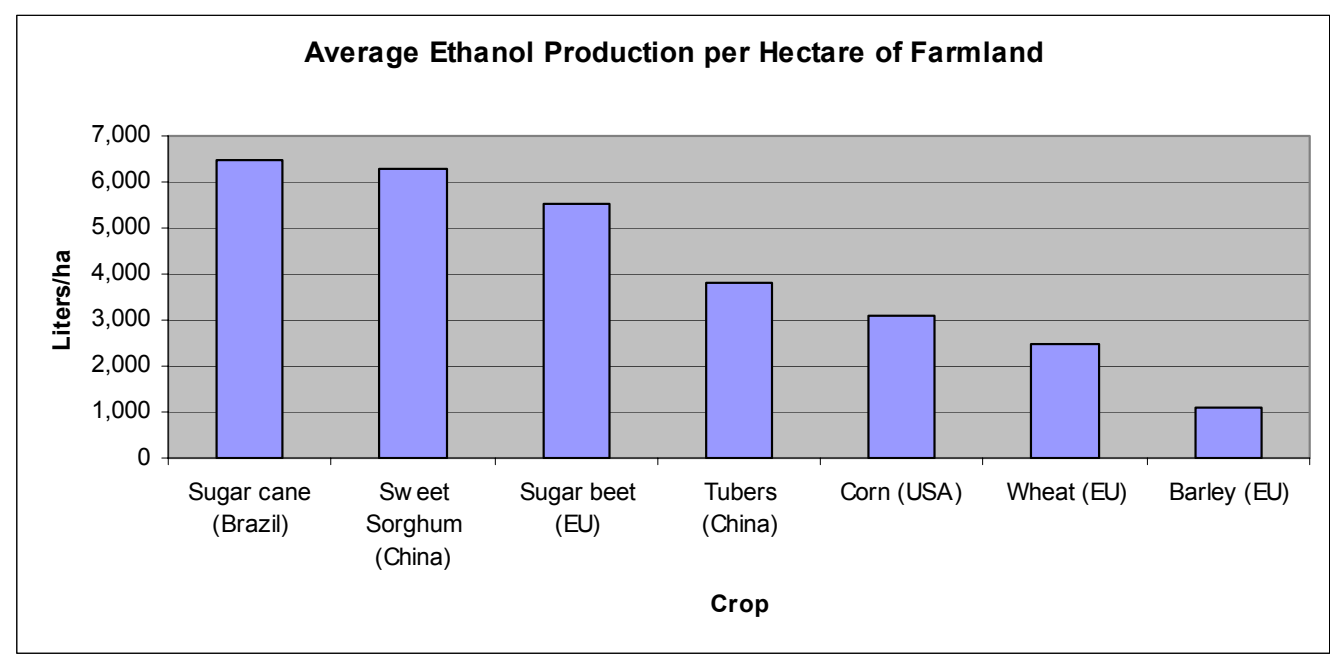

Source: Worldwatch Institute, 2007; USDA, GAIN Biofuels Report for China, 2007

Figure 7 Average Ethanol Production per Hectare of Farmland Yield by Crop 




Source: Worldwatch Institute, 2007

Figure 8 Average Biodiesel Production per Hectare of Farmland Yield by Crop

Economics. The cost for biofuels production in the APEC region varies widely and depends heavily on the cost of feedstock. For ethanol production, feedstock is about $60-75 \%$ of total cost; and for biodiesel production, it is $80-90 \%$. Figures 9-10 show ethanol and biodiesel production costs for a set of APEC economies, compiled from recent publications or provided by authorities in APEC economies. These are illustrative estimates because they vary in the years they were developed (2006-2007).

Figures 9-10 illustrate the cost of producing biofuels from traditional or first-generation feedstock. Regarding second-generation feedstock, it is expected that a successful implementation of the advanced technologies could lead to significant reductions in the cost of producing biofuels. The National Renewable Energy Laboratory (NREL) estimates that the cost of producing ethanol from lignocellulosic biomass is currently $0.53-0.66 \mathrm{USD} \mathrm{L}^{-1}$ and could be reduced further with appropriate technical progress as shown in Figure 11. NREL's estimates for biodiesel production from algae, at current algae productivities, are prohibitively high: 1.50$2.00 \mathrm{USD} \mathrm{L}^{-1}$. An aggressive and perhaps long - term research effort will be necessary to make it economically feasible. 


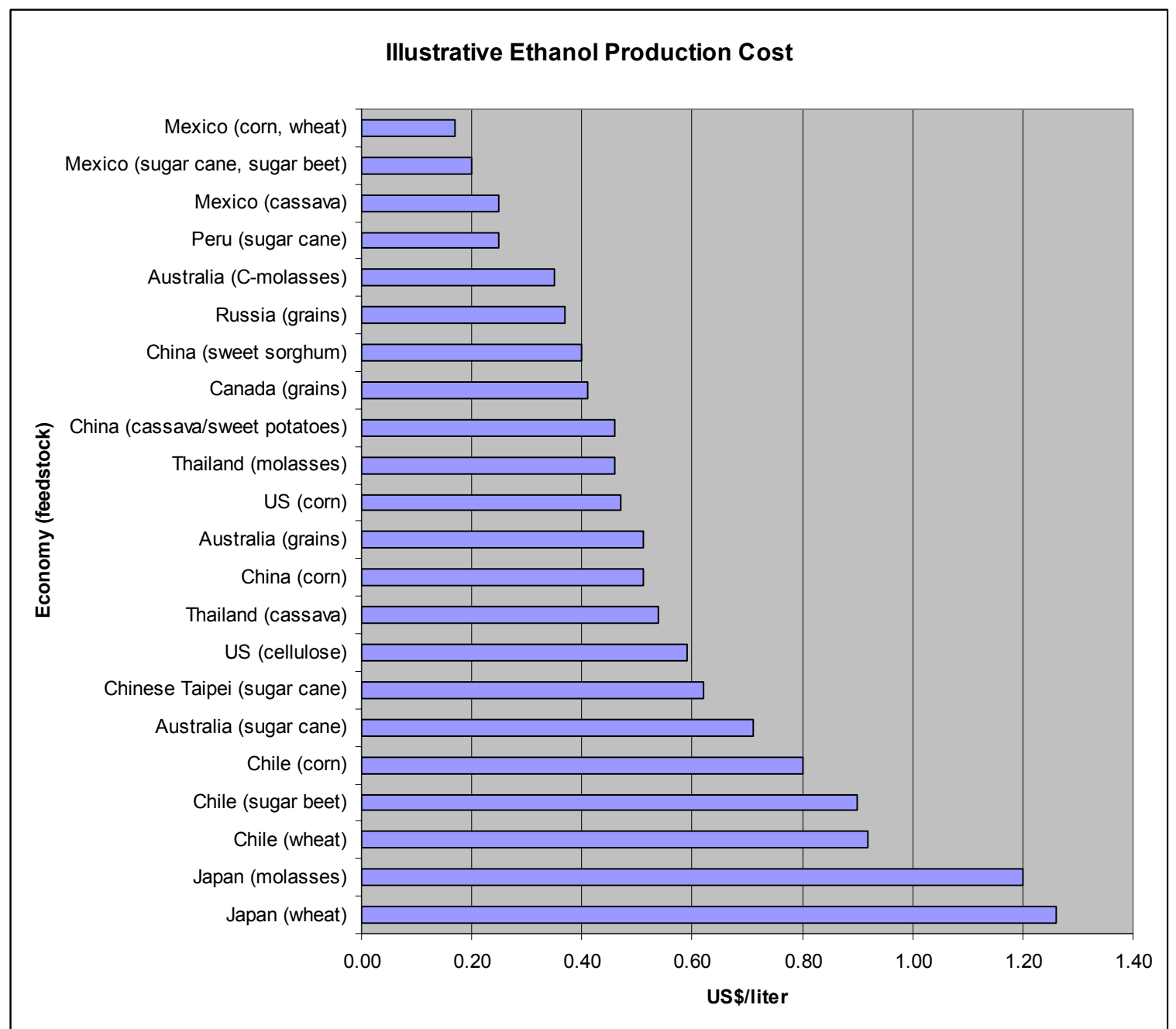

Note: The energy density of a liter of fuel ethanol is $70 \%$ that of gasoline. Mexico and Canada estimates are for 2006 and all others for 2007.

Figure 9 Illustrative Ethanol Production Costs

\footnotetext{
${ }^{6}$ Source: RIRDC/CSIRO, 2007; USDA, GAIN Russia Biofuels, 2007; DEDE, 2007; NDRC, 2007; Palmas e Industrias del Espino, 2008; ITRI, 2007; SENER-BID-GTZ, 2006; CRFA, 2006; UN ECLAC, 2007; Tatsuji Koizumi and Keiji Ohga, 2007; NREL, 2007.
} 


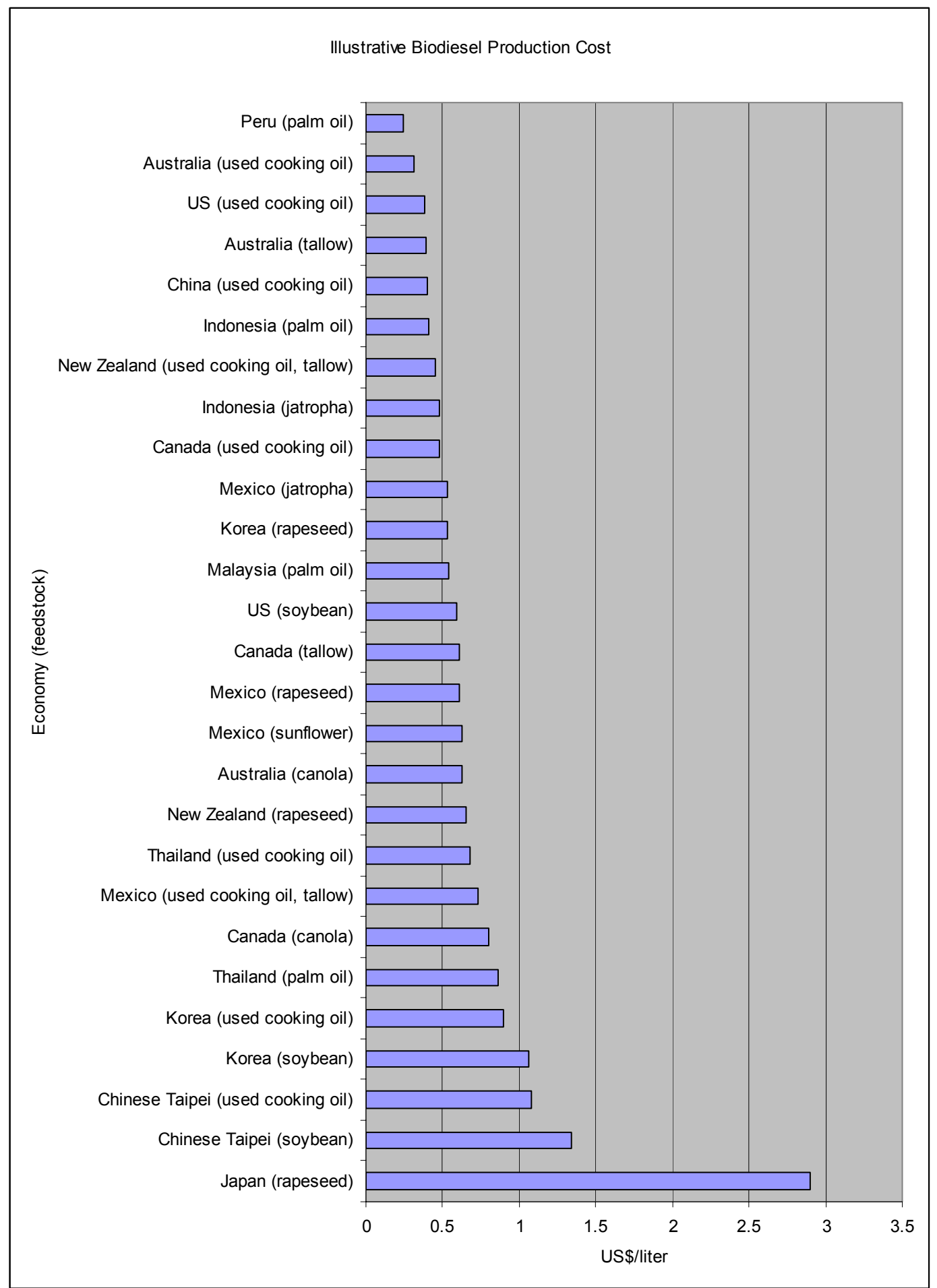

Note: The energy density of a liter of biodiesel is $90 \%$ that of petro diesel. New Zealand estimates are for 2003, Mexico and Canada estimates are for 2006, and all others for $2007 .{ }^{7}$

Figure 10 Illustrative Biodiesel Production Costs

\footnotetext{
${ }^{7}$ Source: RIRDC/CSIRO, 2007; DEDE, 2007; NDRC, 2007; Palmas e Industrias del Espino, 2008; KEEI, 2007; ITRI, 2007; SENER-BID-GTZ, 2006; CCGA, 2006; APEC BTF, 2007; Tatsuji Koizumi and Keiji Ohga, 2007; EECA, 2003; NREL, 2007.
} 


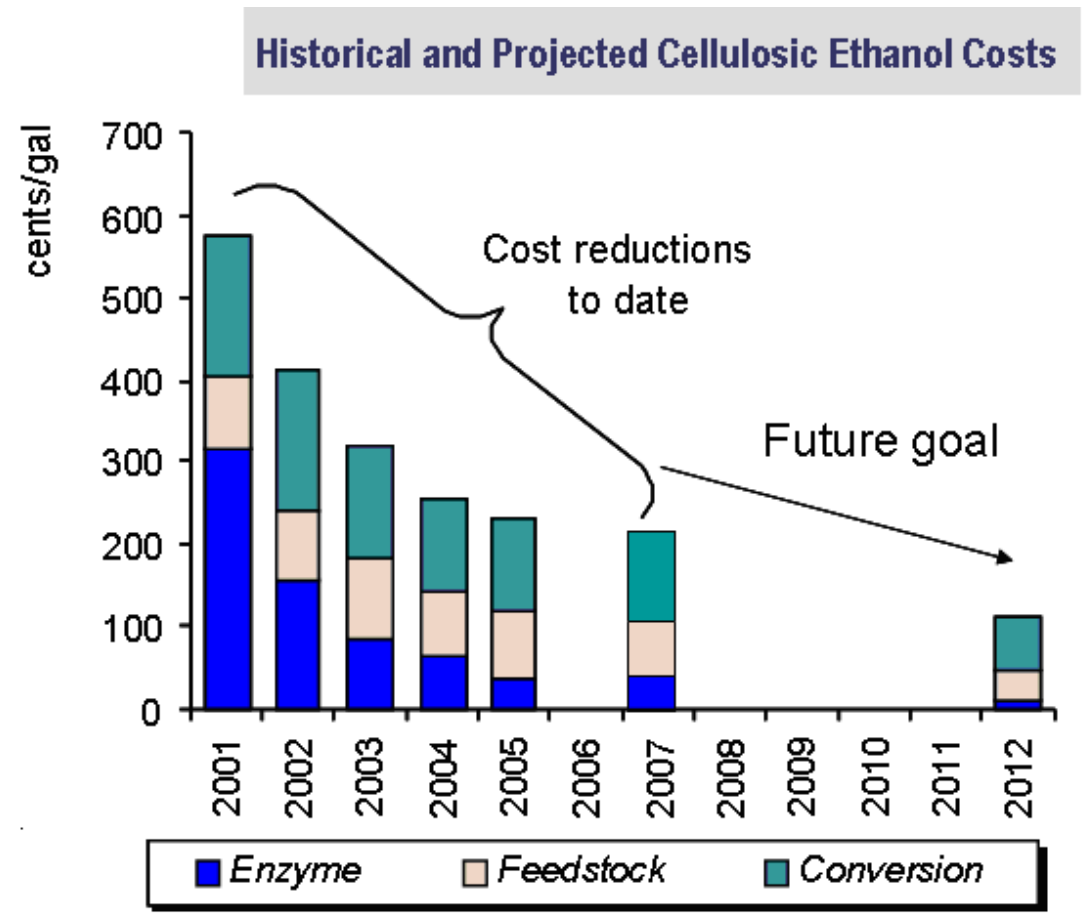

Source: NREL Modeled Cost, 2008

Figure 11 Historical and Projected Cellulosic Ethanol Costs

Biofuels in Use. Ethanol and biodiesel in the APEC region are used in various blends with gasoline and petro-diesel (Table 5). Low- level blends (below E10 and B5) don't require modifications to the existing vehicle engines and refueling infrastructure, thus they are most commonly used. The United States and Australia have been testing the use of E20 in regular vehicles. In March 2008, the U.S. State of Minnesota, after a yearlong research effort, announced that increasing the amount of ethanol blended into gasoline from $10 \%$ (E10) to $20 \%$ (E20) does not present problems for current vehicles or fuel-dispensing equipment and provides similar power and performance. Minnesota and its partners will soon apply to the Environmental Protection Agency (EPA) for a waiver to federal rules that will allow E20 to be used in all of the state's gasoline. In January 2008, Thailand began sales of E20 for use in E20-compatible vehicles. 
Table 5 Biofuels Currently Used in the APEC Region

\begin{tabular}{|c|c|c|}
\hline Economy & Ethanol & Biodiesel \\
\hline Australia & $\mathrm{E} 10$ & Different blend levels from B2 to B100 \\
\hline Brunei Darussalam & 0 & 0 \\
\hline Canada & $\begin{array}{l}\text { E5 (Ontario), E7.5 ( Saskatchewan), and } \\
\text { E8.5 (Manitoba); limited offer of E85 }\end{array}$ & $\mathrm{B} 2, \mathrm{~B} 5, \mathrm{~B} 20$ \\
\hline Chile & 0 & 0 \\
\hline China & E10 is used in 5 provinces and 27 cities & $\mathrm{N} / \mathrm{A}$ \\
\hline Hong Kong, China & $\mathrm{N} / \mathrm{A}$ & $\mathrm{N} / \mathrm{A}$ \\
\hline Indonesia & E5 & B2.5, B5 \\
\hline Japan & E3 & $\mathrm{N} / \mathrm{A}$ \\
\hline Korea & $\mathrm{N} / \mathrm{A}$ & $\mathrm{B} 5, \mathrm{~B} 20$ \\
\hline Malaysia & $\mathrm{N} / \mathrm{A}$ & $\begin{array}{l}\text { Envo Diesel - 95\% petroleum diesel } \\
\text { and } 5 \% \text { processed palm oil (RBD palm } \\
\text { olein); B5 }\end{array}$ \\
\hline Mexico & 0 & 0 \\
\hline New Zealand & E10 at three sites in Auckland & $\mathrm{N} / \mathrm{A}$ \\
\hline Papua New Guinea & $\mathrm{N} / \mathrm{A}$ & SVO at differend blend levels \\
\hline Peru & 0 & 0 \\
\hline The Philippines & E10 & B1 \\
\hline Russia & 0 & 0 \\
\hline Singapore & $\mathrm{N} / \mathrm{A}$ & $\mathrm{N} / \mathrm{A}$ \\
\hline Chinese Taipei & E3 & $\mathrm{B} 1$ to $\mathrm{B} 20$ \\
\hline Thailand & E10, E20 & $\mathrm{B} 2, \mathrm{~B} 5$ \\
\hline United States & E10, E85 & $\mathrm{B} 2, \mathrm{~B} 5, \mathrm{~B} 20, \mathrm{~B} 100$ \\
\hline Viet Nam & 0 & 0 \\
\hline
\end{tabular}

Higher-level blends (such as E85 and B100) are used in special vehicles (FFVs or dedicated biofuels vehicles), thus their market is relatively small. In the APEC region, E85 is offered nationwide only in the United States and in limited volume in Canada. Thailand and Australia plan to introduce E85 in the next few years. B100 is offered in the United States and Australia to serve professional fleets.

Refueling Infrastructure. Service stations in many economies are offering low-level ethanol and biodiesel blends. ${ }^{8}$ However, only the United States in the APEC region has an established E85 refueling infrastructure. The number of stations offering E85 increased from around 100 in 2000 to 1,200 in 2007 (Figure 11). In Canada, two E85 stations were open in 2007, and two refueling stations are to come online in Australia.

\footnotetext{
${ }^{8}$ See Appendix A for more information on number of stations offering biofuels in each APEC economy.
} 




Source: NREL, 2008

Figure 12 United States E85 Refueling Stations

A recent NREL survey found that adding E85 equipment to existing gasoline stations cost an average $\$ 71,700$ USD for a new tank and \$21,000 USD for converting an existing tank (Table $6)$.

Table 6 Cost of Adding E85 Equipment to Existing Gasoline Stations

\begin{tabular}{|c|c|c|c|c|}
\hline Scenario & Cost & Source* & Description & Major Variables Affecting Cost \\
\hline \multirow{5}{*}{$\begin{array}{l}\text { New tank, } \\
\text { new or retrofit } \\
\text { dispenser(s) }\end{array}$} & $\begin{array}{l}\text { Mean: } \$ 71,735 \\
\text { Median: } \$ 59,153\end{array}$ & NREL Survey & \multirow{5}{*}{$\begin{array}{l}\text { Includes new } \\
\text { storage tank, pump, } \\
\text { dispenser(s), piping, } \\
\text { wiring, excavation, } \\
\text { and concrete work }\end{array}$} & \multirow{5}{*}{$\begin{array}{l}\text { Dispenser needs, excavation, } \\
\text { concrete work, sell backs, canopy } \\
\text { tank size, location, labor price, } \\
\text { regulations }\end{array}$} \\
\hline & $\$ 50,000-\$ 200,000$ & NACS & & \\
\hline & $\$ 50,000-\$ 70,000$ & DOT, EPA, DOE & & \\
\hline & $>\$ 50,000$ & NEVC & & \\
\hline & $<\$ 62,407$ & DAI & & \\
\hline \multirow{4}{*}{$\begin{array}{l}\text { Convert } \\
\text { existing tank, } \\
\text { new or retrofit } \\
\text { dispenser(s) }\end{array}$} & $\begin{array}{l}\text { Mean: } \$ 21,031 \\
\text { Median: } \$ 11,237\end{array}$ & NREL Survey & \multirow{4}{*}{$\begin{array}{l}\text { Tank cleaning, } \\
\text { replace non-compatible } \\
\text { components in piping } \\
\text { and dispensers }\end{array}$} & \multirow{4}{*}{$\begin{array}{l}\text { Dispenser needs, number of } \\
\text { non-compatible components, } \\
\text { location, labor price, regulations }\end{array}$} \\
\hline & $\$ 19,000-\$ 30,000$ & DAI & & \\
\hline & $\$ 5,000-\$ 30,000$ & DOT, EPA, DOE & & \\
\hline & $\$ 2,500-25,000$ & NEVC & & \\
\hline
\end{tabular}

Source: NREL, 2008

The survey noted that the stations with the lowest costs $(\$ 3,000$ USD) took conversion shortcuts that are not recommended because of concerns about safety and materials. These shortcuts included failing to clean the tank before filling it with E85, declining to replace equipment components that may not be compatible with E85, and excluding signage costs. The U.S Energy Information Administration (EIA) estimates that the investment in an E85 pump that dispenses one-half the volume of an average unleaded gasoline pump (about 160,000 gallons per year) would require an increase in retail prices of 2 to 7 cents per gallon if the costs were to 
be recouped over a 15-year period. The costs would vary, depending on annual pump volumes and the extent of the station retrofit. The installation cost of E85-compatible equipment for a new station is nearly identical to the cost of standard gasoline-only equipment (EIA 2007).

With respect to biodiesel, NREL assesses the cost of adding biodiesel tanks and dispensers in three scenarios:

Scenario 1: A station replaces petroleum diesel with a B2 to B20 blend. This generally requires only signage and new nozzles to alert customers.

Signage: Average \$1,650 USD (Range \$444-3,250 USD. Sample size 6)

Two nozzles (most stations need two). Average: \$290 USD (Range \$240-340 USD. Sample size 4)

Labor: minimal

Total: $\$ 1,940$ USD

Scenario 2: A station replaces petroleum diesel with B100 or uses an old, dirty diesel tank that needs cleaning. Cost is the same as above, but add tank cleaning to it.

Tank Cleaning: Average: \$1,960 USD (Range: \$1,500-4,355 USD, sample size 12)

Total: $\$ 3,900$ USD for a tank cleaning, signs, and nozzles.

Scenario 3: Add a new tank and new dispenser. This includes excavation, piping, wiring, and other labor. The cost varies: $\$ 20,000$ USD, $\$ 30,000$ USD, and $\$ 45,000$ USD based on three stations in the US state of Indiana where biodiesel tanks and dispensers were installed.

Alternative Fuel Vehicles. E20-compatible vehicles are gaining interest in Thailand due to the excise tax on vehicles taking effect January $2008 .{ }^{9}$ Ford pioneered E20-compliant vehicles in Thailand more than three years ago. Toyota, the local market leader, will only introduce E20 cars, likely sometime in 2008, once it determines that its new E20 engines are efficient. Honda Automobile (Thailand) Co. announced that all of its 2008 car models would be E20-compliant. E20 cars in Thailand are also available from Mazda, Mitsubishi, and Nissan.

\footnotetext{
${ }^{9}$ The cabinet approved an excise tax reduction for car using gasoline containing at least $20 \%$ of fuel ethanol, proposed by the excise department and effective January 1, 2008.
} 
FFVs, as mentioned above, are designed to run on straight gasoline or any gasoline-ethanol blend up to E85 from a single tank. FFVs are available mainly in the United States (about 6 million vehicles) and a small number are available in Canada and Australia. The US National Highway and Traffic Safety Administration gives vehicle manufacturers corporate average fuel economy credits as an incentive for their production. Therefore, FFVs have a tangible economic benefit to manufacturers and are offered to consumers at no incremental cost. Vehicle manufacturers estimate that the cost of converting a conventional vehicle to an FFV in the original manufacturing process is less than $\$ 100$. FFVs available in the US and Canadian markets are from Dodge, Chevrolet, Ford, GM, Daimler-Chrysler, Jeep, Nissan, Pontiac, and Saturn. Saab 9-5 2.3t was introduced to Australian customers in 2007.

Dedicated ethanol vehicles are not available in the APEC region. Volkswagen, Fiat, GM, and Ford have been producing these types of vehicles for many years, predominately for the Brazilian market.

Trade. Currently, there is no specific customs classification for fuel ethanol. Ethanol is traded in the APEC region and around the world as potable and denatured (unfit for human consumption). Ethanol is denatured for fuel and industrial purposes, with, for example, acetone and methanol added according to customer specifications. Gasoline is used as denaturant for fuel ethanol. Both denatured and potable alcohol can be used for biofuel production. Thus, it is difficult to establish from trade flows which share of imported alcohol is used in biofuel production.

World ethanol trade has been relatively stable over the years, less than $4 \mathrm{hm}^{3}\left(1.0 \mathrm{hm}^{3}=10^{6} \mathrm{~m}^{3}\right.$ $=10^{9}$ liter) per year. However, the situation changed in 2005-2006 when the trade volume increased to about 5.0 and $7.8 \mathrm{hm}^{3}$ respectively (F.O.Licht 2007). The steep increase in ethanol trading in 2006 was mostly due to the removal of fuel additive methyl tertiary butyl ether (MTBE) in the United States, which led to the import of large volumes of ethanol from Brazil; China; and Canada.

In 2007, APEC economies imported about $3.4 \mathrm{hm}^{3}$ of ethanol. This includes extra- and intraregional trade, and it is slightly lower than in 2006. The largest importer in the region and worldwide is the United States, which imported close to $2 \mathrm{hm}^{3}$ of ethanol in 2007, down from 2.7 $\mathrm{hm}^{3}$ in 2006. This reduction is mostly due to increased domestic production in the United States 
a trend seen in other economies such as Thailand; Indonesia; and the Philippines. The second largest importer of ethanol in the region in 2006 and 2007 was Japan, about $0.4 \mathrm{hm}^{3}$ annually; however, statistics suggest that it was used as beverage and industrial alcohol. Canada has increased its ethanol import substantially (mostly from the United States) from about $0.1 \mathrm{hm}^{3}$ in 2006 to $0.4 \mathrm{hm}^{3}$ in 2007 to supplement domestic fuel ethanol production. Korea is also a large importer in the region with approximately $0.25 \mathrm{hm}^{3}$ annually; but, as with Japan, it is not for fuel purposes. The push for ethanol use as a transportation fuel has led Australia and Chile to increase the volume of imported ethanol. Although China reduced ethanol imports in 2007, it may become a major importer in the region if E10 is extended across the economy. Local production will not be able to meet expected demand, even though China is looking at alternative feedstock such as cassava and sweet sorghum.

Ethanol exports from the APEC region in 2007 were around $1 \mathrm{hm}^{3}$, down from $1.3 \mathrm{hm}^{3}$ in 2006 . China was the major exporter in the region in 2006, with about $1 \mathrm{hm}^{3}$ shipped to the United States. However, the economy has reduced its export dramatically, mainly due to concerns over meeting domestic biofuels targets. Biofuels targets are also the reason for declining ethanol export from Canada; Australia; and New Zealand. On the other hand, economies with no concrete biofuels targets (such as Indonesia and Viet Nam) have expanded their ethanol exports as additional sources of revenue. Thailand also substantially increased ethanol exports in 2007. Although the Thai Government discourages ethanol exports to guarantee sufficient domestic supplies, the export is expected to grow as the local production increases. In 2007 , the largest exporter in the region was the United States with about $0.6 \mathrm{hm}^{3}$, predominantly for Canada; the United Kingdom (UK); and Mexico.

Biodiesel trade in the APEC region and around the world is not significant. Because the European Union (EU) is the world's largest producer and consumer of biodiesel, it is the main destination of biodiesel produced in the APEC region. There is, however, a small amount of biodiesel traded within the region. Malaysia exported about $60,000 \mathrm{~m}^{3}$ of palm oil-based biodiesel to the United States; EU; and Japan in 2006-2007. Chemrez Inc., a company based in the Philippines, has exported $500 \mathrm{~m}^{3}$ of coconut-based biodiesel to Germany and to Asian markets including China; Chinese Taipei; South Korea; and Malaysia. Indonesia exported small amounts of biodiesel to China; the EU; and the United States. Natural Fuels Australia Ltd exported $8,800 \mathrm{~m}^{3}$ of palm oil biodiesel to the United States and Asia. 
Using vegetable oils as feedstock for biodiesel has increased the demand and has led to significant increase in trade of major oilseeds and products. According to the Food and Agricultural Policy Research Institute (FAPRI), world trade in vegetable oils is anticipated to continue to increase in the next 10 years, with palm and soybean oil accounting for the major part of the expansion (Appendix B). Even today, these two crops account for about $85 \%$ of global oilseeds export (Worldwatch Institute 2007).

Although most biofuels and feedstocks in the APEC region are produced and consumed in domestic markets, there is enormous potential for trade between APEC and non-APEC economies (biotrade). Despite valid concerns about the environmental and food security implications of biofuels, such trade, if done right, could generate significant economic, environmental, and social benefits. For biotrade to be successful there is a need for the specifications, testing, and use to be regulated by means of internationally accepted standards. Unlike their petroleum counterparts, the biofuels of today are subject to different specifications in different jurisdictions. Without harmonization and improvement of these standards, it could become a barrier to trade. Brazil; the EU; and the United States formed the Tripartite Task Force in 2007 to address these standardization issues. The Task Force recently completed a review of existing bioethanol and biodiesel standards, identifying where greater compatibility could be achieved in support of the global commoditization of biofuels (Tripartite Task Force 2007). In 2007, the APEC Energy Working Group initiated a project to establish guidelines for development of biodiesel standards in the region (APEC EWG 2008). An APEC Energy Trade and Investment Study will identify existing barriers to energy trade and investment in the APEC region. An APEC Energy Trade and Investment Roundtable meeting will be held in Cairns, Australia, on September 24-25, 2008, to develop a plan addressing these trade and investment impediments.

Policy. There are various levels of government involvement and support for biofuels development in the APEC region. While governments in some economies such as Indonesia; Mexico; Russia; and Viet Nam have expressed interest and support for the biofuels industry, there are no policies in place. On the other hand, the governments of Australia; Canada; China; Thailand; and the United States have adopted a range of policy instruments that affect the production and consumption of biofuels. 
The most common policy supporting biofuels in the APEC region is the mandate for compulsory blending with fossil fuels to a certain percentage (Table 7). Other policy instruments include fuel excise-tax exemptions and rebates (full or partial); government fleet requirements to use biofuels; tax-exempt bonds for finance (particularly in the United States); subsidized loans and loan guarantees; biofuels producer credits; subsidies toward purchase of vehicles and infrastructure that can use biofuels; subsidies not normally associated directly with biofuels, such as agricultural farm support; environmental legislation mandating certain types of fuel additives (typically for fuel oxygenation) related to reducing vehicle exhausts; and governmentsupported research, development, and demonstration funding for current and next-generation biofuels and technologies. Greater detail on these and other programs applied in each economy is provided in Appendix A. 
Table 7 Biofuel Mandates and Targets in APEC Economies

\begin{tabular}{|c|c|c|}
\hline \multirow{2}{*}{ Economy } & \multicolumn{2}{|c|}{ Biofuels Mandates and Targets } \\
\hline & Ethanol & Biodiesel \\
\hline Australia & \multicolumn{2}{|c|}{ A biofuels target of at least 350 million litres by 2010} \\
\hline Brunei Darussalam & $x$ & $x$ \\
\hline Canada & E5 by 2010 & $\mathrm{~B} 2$ by 2012 \\
\hline Chile & $\begin{array}{l}\text { Plans to introduce voluntary } \\
\text { E5 in } 2008\end{array}$ & $\begin{array}{l}\text { Plans to introduce voluntary } \\
\text { B5 in } 2008\end{array}$ \\
\hline China & $\begin{array}{l}\text { Increase production to } 3 \\
\text { million tonnes/year by } 2010 \\
\text { and to } 10 \text { million } \\
\text { tonnes/year by } 2020\end{array}$ & $\begin{array}{l}\text { Increase production to } \\
300,000 \text { tonnes/year in } 2010 \\
\text { and } 2 \text { million tonnes/year in } \\
2020\end{array}$ \\
\hline Hong Kong, China & $x$ & $x$ \\
\hline Indonesia & \multicolumn{2}{|c|}{$\begin{array}{l}2 \% \text { biofuels in the energy mix by } 2010 ; 3 \% \text { by } 2015 ; \\
5 \% \text { by } 2025\end{array}$} \\
\hline Japan & 500 million liters by 2010 & $\mathrm{X}$ \\
\hline Korea & $\mathrm{X}$ & $\mathrm{B0} .5 ; \mathrm{B} 3$ by 2012 \\
\hline Malaysia & $x$ & $\begin{array}{l}\text { B5 was planned to be } \\
\text { mandated in } 2008 \text {. } \\
\text { Government suspended } \\
\text { implementation due to the } \\
\text { palm oil supply and price } \\
\text { considerations }\end{array}$ \\
\hline Mexico & $x$ & $x$ \\
\hline New Zealand & \multicolumn{2}{|c|}{$\begin{array}{l}\text { Biofuels to account for } 0.53 \% \text { of total fuels sold in New } \\
\text { Zealand in } 2008 \text { and increase to } 3.4 \% \text { by } 2012\end{array}$} \\
\hline Papua New Guinea & $\mathrm{X}$ & $\mathrm{X}$ \\
\hline Peru & E7.8 in 2010 & $\mathrm{~B} 2$ in 2009; $\mathrm{B} 5$ in 2011 \\
\hline The Philippines & E5 by 2009; E10 by 2011 & $\begin{array}{l}\text { B1 since May } 2007 \\
\text { possibly } \mathrm{B} 2 \text { in } 2009\end{array}$ \\
\hline Russia & $\mathrm{X}$ & $x$ \\
\hline Singapore & $\mathrm{X}$ & $\mathrm{X}$ \\
\hline Chinese Taipei & E3 in 2011 & $\mathrm{X}$ \\
\hline Thailand & $x$ & $\begin{array}{l}\text { B2 since February 2008; } \mathrm{B} 5 \\
\text { in 2011; } \mathrm{B} 10 \text { in } 2012\end{array}$ \\
\hline United States & \multicolumn{2}{|c|}{7.5 billion gallons of biofuel by 2012} \\
\hline Viet Nam & 500 million liters by 2020 & 50 million liters by 2020 \\
\hline
\end{tabular}




\section{The Future of Liquid Biofuels in APEC Economies}

The production and consumption of liquid biofuels in the APEC region has increased substantially during the past few years, in response to several factors: energy security, urban air quality, climate change, and rural development. These drivers operate with different weights within the APEC grouping. Heavily urbanized economies favor urban air quality as well as the climate change offset potential with some energy security emphasis. Agricultural economies with high levels of food security have favored the rural development and stabilization of agriculture that comes from having additional product demands. In the United States, up until recently, the primary drivers have been energy security, agricultural development, and urban air quality.

For several economies, which are characterized by high population densities and relatively low areas of arable land per capita (Japan; Singapore; Chinese Taipei; Hong Kong, China; and Republic of Korea), the prospects of producing a significant amount of biofuels from domestic feedstock are very limited. Other than wise use of residues from industries and the urban areas, crop-based opportunities are limited; and the options beyond relatively minor use of residues are primarily as biofuels importers. However, an opportunity exists for some of these economies to import feedstock, process it domestically into biofuels to supplement local production, or export it. Singapore, for example, benefits greatly from its proximity to the palm oil industries in Malaysia and Indonesia, which (coupled with the fact that it is a diesel-driven economy) drives the economy's biofuels strategy toward biodiesel.

Several other member economies have the potential not only to satisfy current technically feasible levels of first-generation biofuels substitution (i.e., 5-10\% of the domestic diesel and gasoline demands, respectively) but also to become exporters. These include Indonesia, Malaysia, Thailand, Papua New Guinea, the Philippines, Canada, and Russia. The United States has such a high internal transportation fuel demand that it will likely continue both as a major domestic producer and importer of biofuels.

Another member economy is taking a different approach. Brunei Darussalam hopes to position itself as a major methanol (from natural gas) supplier in the region. It is expected that the methanol demand will grow with potential applications such as biodiesel and DME (dimethylether) - the world demand is 36 million tonnes per year, and it has been growing at $3 \%$ per year. 
Especially in Asia, where the joint venture Brunei Methanol Company (BMC) aims at exporting methanol, a higher demand is forecasted due to the higher economic growth rate than other regions (MGC 2007).

Biofuels production and consumption in the APEC region is projected to grow, but the rate of growth will depend on several factors - the primary one is economics of production.

Economic Drivers for Biofuels. The so-called first-generation (Gen-1) biofuels (ethanol and FAME-biodiesel) are produced from sugars derived from sugarcane, sugar beet, and cereals in the case of ethanol; and from fats, oils, and greases (FOG) for biodiesel. These first-generation biofuels are based on food and animal feed commodities, and the consumption of these for biofuel are in competition with agricultural product markets. In retrospect, it was obvious that established and well-developed crop production systems would be the first to be used for biofuels. The infrastructure, existing capital investment, and human capital were all in place. Cereals at more than $2 \mathrm{Gt} \mathrm{yr}^{-1}$ production represent the majority of the solar energy captured by agriculture, and have been under continuous development for centuries with particularly rapid advances in productivity since the 1950s. Oilseed crops also have had an extraordinary growth rate in the past 50 years. Their use for energy is, of course, an economic decision, which was assisted by financial subsidy policies in pursuit of one or more of the goals identified above.

The relationship between crude oil prices and foodstuffs has, in fact, changed during the past 40 years. Prior to the oil crises of 1973 and 1981, it was a truism that when oil and food were compared on the basis of their energy content, the ratio of food price to oil was often > 10:1. This started to change in the 1980s, after the second of the world's oil shocks and a ratio decrease of 2 - 4 (except for periods when food commodity prices spiked on adverse weather or policy shifts in land set-asides and subsidies). One particular commodity crop, maize, was less than double the oil price for much of the 1990s, and the absolute difference of less than $3 \$$ GJ $^{-1}$ was surmounted by the early US gasohol subsidy regime worth around $6 \$ \mathrm{GJ}^{-1}$. With added capital incentives and the ability of farmers to sell directly to the local ethanol plant - which offset the transportation and logistics costs of getting corn to commodity markets - a financially profitable industry was started. However, starting in the early 2000 s, the price of corn became equal to or less than that of crude oil. Even world sugar prices are close to the price of crude oil on an energy basis. This provided an even greater incentive for biofuels production. 
This post-2000 change is reflected in the commodity index of the International Monetary Fund (IMF) (Figure 13), which highlights the rapid increase in almost all commodities except for agricultural raw materials including timber and wood products. The petroleum index overtook food at the end of 2005, and this meant, for the first time, that renewable carbon-based energy was priced at about the same or less than that of petroleum energy.

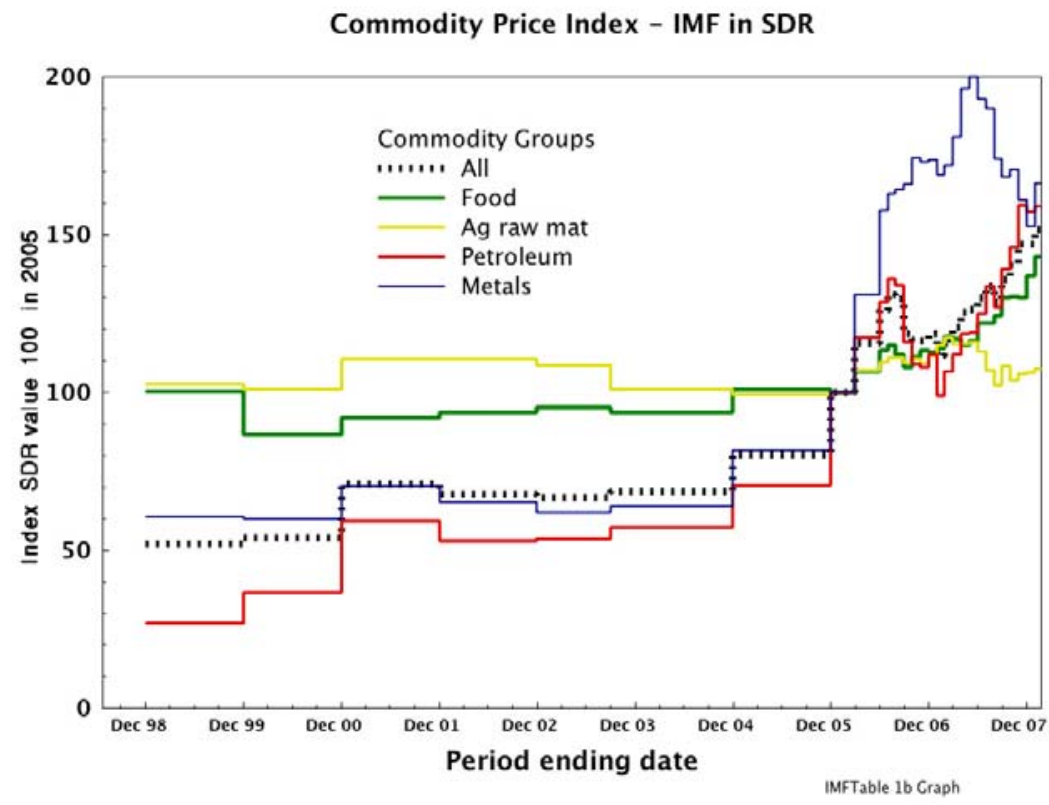

Source: IMF, 2008

Figure 13 Commodity Price Index - IMF in SDR

Figure 14 shows the evolution of crude oil prices (in dollars of the year) against that of major food commodity crops from the market prices posted in the United Nations Conference on Trade and Development (UNCTAD) database. 


\section{Food Commodity and Crude Oil Price Trends.}

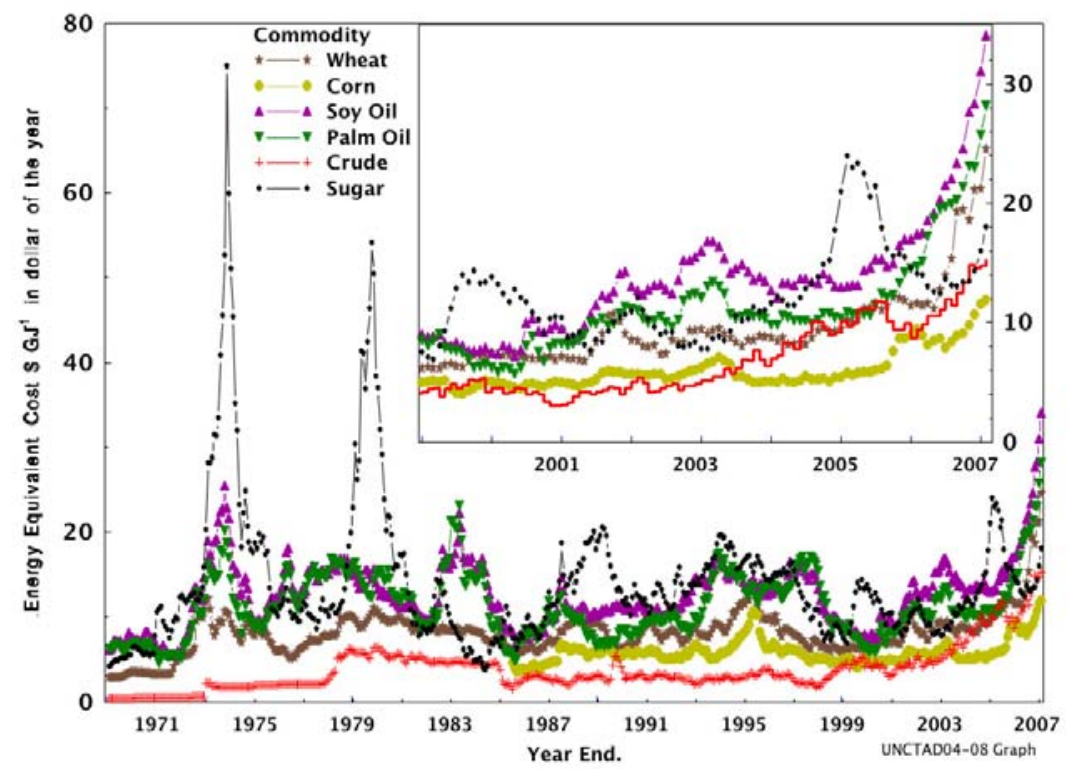

Source: UNCTAD, 2008

Figure 14 Food Commodity and Crude Oil Prices Trends

The recent price increases in food and feed are causing concern, especially for the rural and urban poor who are not self-sufficient and for whom food already represents most of their income. Biofuels policies are being scrutinized as a contributor to demand at a time when increasing meat consumption is diverting grains from food to feed; and after a series of crop failures due to drought in Australia have decreased the ratio of stocks to consumption to the lowest levels in several decades - since 1995, stock levels have declined by $3.5 \% \mathrm{yr}^{-1}$ (IFAD 2008). However, agriculture is facing stresses without biofuels. While the population has increased at a somewhat constant rate of 70 million per year for the past 12 years, the increase in cereal production seems only to be keeping pace; in fact, per capita cereal availability has been constant at about $340 \mathrm{~kg}$. Meat production, however, has been increasing rapidly with the per capita consumption increasing at a constant rate of $550 \mathrm{~g}$ per person per year.

The analysis by the International Fund for Agricultural Development stressed that no single factor can be identified as the primary one responsible for these trends - all contribute. So far, APEC economy responses have been limited. Some have removed import tariffs on some commodities including: maize and sugar in Mexico, wheat and soybeans in Indonesia, and reductions on the wheat and maize tariff in Korea. China has introduced export levies on wheat and other cereals and increased them on maize and soybeans among others. As noted in Appendix A, China has already reduced its goals for maize ethanol and has put a moratorium 
on new maize to ethanol plants. Until lignocellulosic ethanol is commercially available, the transitional feedstocks are sweet sorghum, sweet potatoes, and cassava. Peru is considering subsidizing bread prices to alleviate the stress on the poor. In response to the high prices of palm oil (Figure 15), Malaysia (who had started to promote domestic straight vegetable oil and biodiesel consumption from palm oil) has recently announced that it will not pass its equivalent of a renewable portfolio standard until the price of palm oil has returned to more reasonable levels. As can be seen, the recent crude palm oil (CPO) price (on an energy-content basis) has soared much more rapidly than that of crude oil since 2006, making biodiesel production very uneconomic.

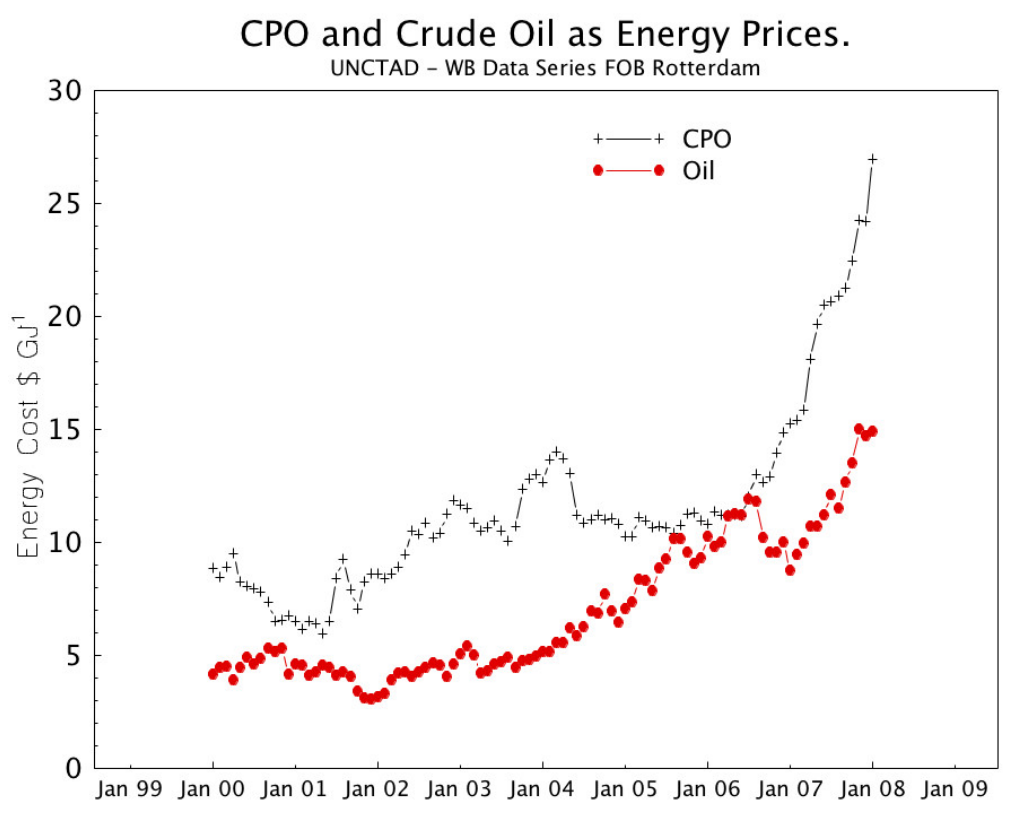

Source: UNCTAD, 2007

Figure 15 CPO and Crude Oil as Energy Prices

Other factors influencing the future development of sustainable biofuels is the need for a balanced scorecard, evaluating the performance of biofuels against the metrics of energy security, GHG reduction, and the energy return on investment (EROI).

Climate Change and GHG Factors. Climate change considerations require that GHG emissions be reduced. Early proposals for automobile regulation in the EU required that vehicles had maximum levels of carbon dioxide (the principal GHG) of $120 \mathrm{~g} \mathrm{~km}^{-1}$ by 2012 . This 1995 proposal for voluntary efforts to reach this level was at a time when the average was $186 \mathrm{~g}$ 
$\mathrm{km}^{-1}$. The target level will not be reached voluntarily - the average was $163 \mathrm{~g} \mathrm{~km}^{-1}$ in 2004, and as a result, the EU Commission has proposed mandatory levels that are being opposed by large luxury car manufacturers. One way of meeting the level is to use renewable carbon biofuels that are considered to be carbon-neutral, with the carbon contained in the fuel recently drawn from the atmosphere. The actual substitution of fossil carbon by renewable carbon is measured by means of life-cycle inventory ( $\mathrm{LCl}$ ), a formalized energy and materials accounting process that is part of the life-cycle assessment (LCA) described by ISO (14040). With the full accounting, it is possible to trace the fate of different chemicals in the production chain from field or forest to the wheel. A subset of LCA is often quoted, describing the energy and materials flow from the "Well to Wheels" (WTW), "Well to Tank," (WTT) and" Tank to Wheels" (TTW). The range of estimates for GHG emissions reduction associated with ethanol and biodiesel varies greatly as shown in Tables 8-9.

Table 8 Estimated Change in Life Cycle GHG Emissions per km Travelled by Replacing Gasoline with Various Ethanol Blends

\begin{tabular}{|l|l|l|}
\hline Feedstock and Blend & Emissions Change (\%) & \multicolumn{1}{c|}{ Source } \\
\hline Corn & & \\
\hline E10 (US) & -1 & Wang et al (1999) \\
\hline E10 (China) & -3.9 & Wang et al (2005) \\
\hline E85 (US) & -14 to -19 & Wang et al (1999) \\
\hline E85 (China) & -25 & Wang et al (2005) \\
\hline E100 (wet milled) & -25 & Wang et al (2001) \\
\hline E100 (dry milled) & -32 & Wang et al (2001) \\
\hline & & \\
\hline Sugar beet & & \\
\hline E100 (Northern France) & -35 to -56 & Armstrong et al (2002) \\
\hline & & \\
\hline Molasses & & Beer et al (2001) \\
\hline E10 (Australia) & -1 to -3 & Beer et al (2001) \\
\hline E85 (Australia) & -24 to -51 & \\
\hline & & Macedo et al (2004) \\
\hline Sugar cane & & Macedo et al (2004) \\
\hline E100 (Hydrous; Brazil) & -87 to -95 & \\
\hline E100 (Anydrous; Brazil) & -91 to -96 & \\
\hline & & Armstrong et al (2002) \\
\hline Wheat & &
\end{tabular}

Source: Worldwatch Institute, 2007; Assumes use of current generation ethanol fuel in conventional vehicles 
Table 9 Estimated Change in Life Cycle GHG Emissions per km Travelled by Replacing Diesel with B100

\begin{tabular}{|c|c|c|}
\hline Feedstock & Emissions Change (\%) & Source \\
\hline \multicolumn{3}{|l|}{ Rapeseed } \\
\hline Germany & -21 & Armstrong et al (2002) \\
\hline \multirow[t]{2}{*}{ Netherlands } & -40 & Larive (2005) \\
\hline & -49 & GM et al (2002) \\
\hline \multirow[t]{2}{*}{ Australia } & -54 & Beer et al (2001) \\
\hline & -68 & Wuppertal Institute (2005) \\
\hline \multicolumn{3}{|l|}{ Pure plant oil } \\
\hline Unspecified oil source & -42 & Wuppertal Institute (2005) \\
\hline \multicolumn{3}{|l|}{ Soybeans } \\
\hline US (2025) & +107 & Delucchi (2003) \\
\hline Netherlands & -63 & Levelton Engineering Ltd. (1999) \\
\hline Australia & -65 & Beer et al (2001) \\
\hline \multicolumn{3}{|l|}{ Tallow } \\
\hline Australia & -55 & Beer et al (2001) \\
\hline \multicolumn{3}{|l|}{ Used cooking oil } \\
\hline Australia & -92 & Beer et al (2001) \\
\hline
\end{tabular}

Source: Worldwatch Institute, 2007; Assumes use of current generation ethanol fuel in conventional vehicles

The WTW fossil fuel offset and carbon-emissions reduction of the first-generation biofuels, ethanol, and FAME show that the reductions are real for FAME and ethanol from sugarcane. They also show that carbon dioxide reductions of $50-80 \%$ are possible, even when considering other GHG emissions associated with the agricultural cycle such as NOx from fertilizer use. However, for one pathway, the one from maize (in the United States, Zea mays is called corn), the results have been controversial and the subject of heated scientific and political debate. The first analyses showed that the energy return on investment (EROI), defined as the ratio of the energy delivered to the tank (e.g., in a liter of product to the amount of fossil fuel required) was close to unity. If the driver was energy security, this did not matter because most of the fossil fuel was coal or gas - and gasoline would be replaced by domestic energy sources. From the perspective of carbon offset, however, the situation was not at all promising. With more than two decades of process improvement and optimization, the current EROI is $>1.6$, and the carbon offset can be greater than 19\%. Ethanol derived from sugarcane and lignocellulosic materials, using biomass as an energy source in the conversion process, have even greater carbon offsets (Figure 16). 


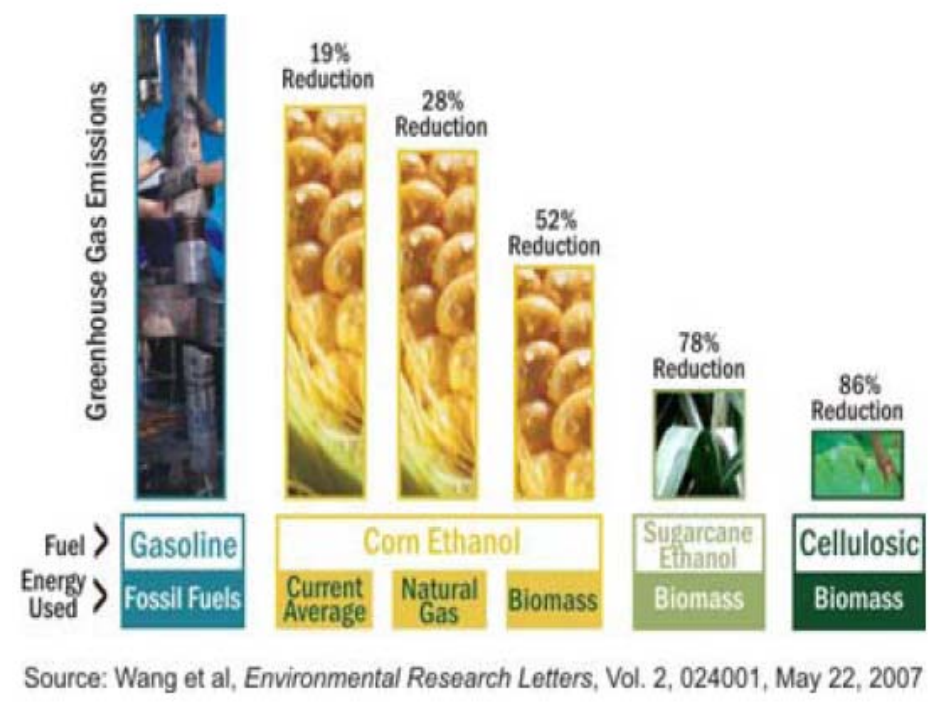

Figure 16 GHG Emissions Reduction Potential for Select Biofuels

Current biofuels legislation targets the EROI and carbon offset, explicitly. The 2007 Energy Act allocates the US renewable fuels standard (RFS) based on the carbon performance of the biofuel. The UK's renewable transport fuel obligation (RFTO) enacts a reporting framework that will reward biofuels based on their carbon savings, and also in accordance with sustainability standards.

The 2007 US RFS, embodied in the Energy Independence and Security Act of 2007 (Sec. 201), recognizes the climate change aspect of biofuels by stating that conventional biofuels such as ethanol from corn starch have to reach at least $20 \%$ reduction of GHG, while advanced biofuels derived from renewable biomass have to achieve a $50 \%$ reduction in GHG. A separate category is created for cellulosic biofuels achieving a $60 \%$ reduction. In the RFS, there is a schedule that limits the amounts of each class of biofuels eligible for renewable fuels credits, as well as investments in the development of advanced biofuels that could offer an $80 \%$ GHG reduction.

Rural Development. The rural development perspective has also changed during the past three decades. In the 1980s, the challenge for developed country agriculture, mainly in the EU and United States, was in the generation of considerable food surpluses that were subsidized by the central governments. To regulate this, the governments were, in effect, buyers of last resort with stockpiles of commodity crops that were either sold cheaply for industrial use, or supplied as food aid to developing countries. This was in addition to requiring the area to be planted to specific commodity crops. Although food shortages were avoided with this system, 
small farmers were driven from the land and replaced by ever-growing agribusiness, which with economies of scale seemed to satisfy the consumers' need for cheaper food. In developing countries, the imports reduced the value of local foodstuffs causing a cycle of reduced incomes and loss of employment in rural agriculture, as well as enhancing the shift of population from rural to urban areas. In both the EU and the United States, the development of commodity product-based biofuels offered a new and initially unregulated market - which with local conversion plants could also offset the transportation costs to commodity market centers. The GHG challenge resulted in biofuels subsidies, which provided further incentives to this deregulated agriculture.

Sustainability and Biotrade. The question of sustainability encompasses all of the above factors and also considers the indirect effects of biofuels demand on other resources. The initial response of agricultural economies to increasing prices for commodities is to increase production. Inevitably, the immediate response is through extension of the land area planted, either by reclaiming land set-asides such as the conservation reserve program (CRP) of the US Department of Agriculture (USDA), or though land-use change (LUC). Additional arable land for crops has to come from the conversion of either grasslands or forest. LUC has implications for a range of sustainable development issues including social development, urban development, and environmental impact. As already mentioned above meeting biofuels targets will depend on the development of international trade in biomass (Biotrade) raw materials or processed biofuels. Biotrade will not only be function of climate and energy policy and economics; it also will impact and be impacted by food, agriculture and forestry policy.

Consumers and NGOs such as FOE and $\mathrm{WWF}^{10}$ have raised concerns about biofuels with particular concern about the rapid increase in the use of palm oil for biodiesel, and have argued that it is a major factor in deforestation, and loss of biodiversity in Indonesia as well as in other parts of the world. This has resulted in consumers in Europe and elsewhere starting to require certification of the sustainable origins of biofuels that they purchase. One scheme that is almost in place is the principles and criteria of the Round Table on Sustainable Palm Oil (www.rspo.org). While participation is voluntary, the certification of suppliers is underway due to the consumer demand, and during late 2008 RSPO certified oil will be on the market. A similar scheme is under development for soybean which is likely to be the other major biodiesel source involved in biotrade.

\footnotetext{
${ }^{10}$ FOE - Friends of the Earth, http://www.foe.org/ ; WWF - World Wildlife Fund, http://www.wwf.org/
} 
While rapid growth in biofuels in the APEC region may be financially curtailed for Gen-1 biofuels due to the commodity price increases, the basic programs and intent to use renewable resources to offset GHG will remain with increasing emphasis on sustainability criteria, especially for the parties engaged in biotrade.

Next Generation Biofuels. The USA; China; and Japan are investing in the development of biofuels based on lignocellulosic resources such as wood and straw. These materials are structural plant components, rather than being an energy storage medium such as a seed. As can be seen in Figure 13, the commodity price index for agricultural raw materials, which includes timber have not seen the same type of increase in cost.

Second generation (Gen-2) biofuels are something of a misnomer, in that the term is applied indiscriminately to both resources and end use fuels. From the resource side, the Gen-2 potential is in non-food crops - in the immediate future from non-edible oils for diesel replacement and lignocellulosics (wood and straw) for both gasoline and diesel replacement. However, up to date the suggested biofuel products are distinctly Gen-1 with large R\&D programs in new oil crops such as Jatropha for biodiesel, and ethanol from the carbohydrate portion of lignocellulosics for gasoline replacement. Gen-2 biofuels would more likely be much more fungible with the hydrocarbon economy. For example renewable diesel a hydrogenated lipid or fatty acid has much better temperature compatibility and miscibility criteria with regular diesel. Fischer Tropsch Liquids (FTL) produced from renewable resources would be indistinguishable from their fossil counterparts in end use applications. Other suggested Gen-2 biofuels include butanol, and various oxygenates derived from aldehydes and acids that can be produced from biomass carbohydrates or aromatics from the lignin component of lignocellulosics.

There are as yet no Gen-2 demonstration plants operating with lignocellulosic feedstocks. Several are either in the late planning or construction stage. The needed investment in Gen-2 is projected to be far higher per annual unit of production than sugarcane ethanol or starch based ethanol with energy efficiencies that will likely be a lower EROI against sugarcane ethanol, but with equal or better GHG offsets. 


\section{Conclusions}

Biofuels received extensive attention in the APEC economies during the past few years, and their production and consumption has increased remarkably in response to major concerns about energy security, urban air quality, rural economic development, and most recently greenhouse gas offsets. The continuing growth of biofuels in the APEC economies is subject to a number of risk factors. For example, increasing biofuels production at a time of generally increasing commodity prices since 2000 has brought biofuels in general into controversy, illustrated by newspaper headlines on "fuel vs. food". Especially in the early part of 2008 when food prices started to rise rapidly and some equated the climate change policy as being in opposition to food security if it is based on the first generation biofuels derived from food and feed commodities. The increase in the price of food commodities has already caused delays in the implementation of previously announced RFS programs in for example Malaysia. In the EU and UK the already announced RFS programs have undertaken public consultation on the sustainability criteria that they will mandate for both domestic biofuels production and biotrade.

All of these factors collected together show that the biofuels future has to address several risks. For Gen-1 biofuels there are few technology risks related to their production. While there is little risk with the accepted levels of fossil fuel substitution by biofuels, the current levels of $5 \%$ for biodiesel and generally $10 \%$ for ethanol in gasoline are insufficient to make a major contribution to offsetting GHG. Moving beyond these levels of fuel substitution without vehicle and engine modification cannot be undertaken without extensive evaluation according to the economy specific climate and fuel distribution systems. Of course the FFV for ethanol up to $85 \%$ substitution is accepted as proven, though only for a limited number of light duty models that have been modified to accept variable ethanol to gasoline ratios.

The non-technical biofuels risks that have emerged in this study are cost of production for Gen1 biofuels, indirect biomass supply risks from other commodity markets using the same feedstocks, social impacts, environmental impacts of land use change, and biodiversity. Each one of these may also be felt through changes of policy and regulation in the renewable fuel standards for each economy. One, which will have an effect in the short term, will be sustainability criteria that will implicitly address food security, and may well dictate the rate of expansion of biofuels even if the current high prices of oil and food commodities are not maintained. Indeed the biomass supply risk may be exacerbated by more than one aspect of 
policy and regulation in the food sector, if for example export controls and tariffs (export or import) overlap with the biofuels sector.

Gen-2 biofuels still have considerable technology risks. Few have been proven even at the demonstration scale. Considerable technology and cost risks are associated with the candidate technologies that will use lignocellulosics as feedstock, though the forest and straw based feedstocks will mostly avoid indirect biomass supply risk from commodity competition, except perhaps with forest products in some economies. Even then there will still be a range of social and environmental impacts in land use change and biodiversity which will have to be accommodated.

Some of the end use biofuels in Gen-2 are much more fungible with the existing hydrocarbon fuels and will have less risk in being used in variable fractions of the fuel supplied to the vehicle which may be a benefit in their introduction. These newer fuels, however, will have significant risk with respect to policy and regulation.

The analysis we have undertaken has also demonstrated that expansion of biofuels in the APEC region will also involve biotrade between resource rich economies and the highly urbanized, with limited arable land economies. Biotrade is already significant for the US as an importer, mainly from non-APEC economies even though its internal production capacity is increasing rapidly. In addition to the risk factors identified above, there are also challenges with respect to standards and regulations for biofuels. Trade will require that the harmonization of the standards between exporters and importers be undertaken, especially for Gen-2 fuels other than ethanol.

Ultimately it may be that region wide collaboration on biofuels standards and regulations including sustainability criteria will be the best means of ensuring a balance of opportunity between biofuel producers and consumers while meeting climate, food, and economic development goals. There are also technology collaboration opportunities that could do much to address technology risk especially for Gen-2 fuels, and cooperatively accelerate their implementation. 


\section{References}

1. Alternative Fuels Data Center, US Department of Energy, Energy Efficiency and Renewable Energy, http://www.eere.energy.gov/afdc/

2. APEC Biofuels Task Force (BTF) Report to the Eight Energy Ministers Meeting, Darwin, Australia, May 2007,

http://www.ewg.apec.org/assets/documents/apecinternet/Biofuelsreport\%5FEMM820071 011104537\%2Epdf

3. APEC Energy Working Group, Establishment of the Guidelines for the Development of Biodiesel Standards in the APEC Region, Report prepared by Hart Energy Consulting, April 2008, http://www.apec.org/apec/publications/all publications/energy working group.html\#200 $\underline{8}$

4. APEC Secretariat, Key outcomes of the Eighth Meeting of APEC Energy Ministers, June 2007, http://www.apec.org/apec/enewsletter/june vol13/onlinenewsb.html

5. Canadian Canola Growers Association (CCGA), http://www.ccga.ca/

6. Canadian Renewable Fuels Association (CRFA), http://www.greenfuels.org/

7. Chemical Economics Handbook (CEH) Marketing Research Report - Ethanol, SRI Consulting, February 2008

8. Chemical Economics Handbook (CEH) Marketing Research Report - Biodiesel, SRI Consulting, November 2006

9. Department of Alternative Energy Development and Efficiency (DEDE), Thailand, http://www.dede.go.th

10. Department of Resources, Energy and Tourism (DRET), Australia, http://www.directory.gov.au/index.php

11. Energy Efficiency and Conservation Authority (EECA), Cost of Biodiesel Production, May 2003, http://www.eeca.govt.nz/eeca-library/renewable-energy/biofuels/report/costof-biodiesel-production-03.pdf

12. Energy Information Administration (EIA), Energy and Economic Impacts of Implementing Both a 25-Percent Renewable Portfolio Standard and a 25-Percent Renewable Fuel Standard by 2025, August 2007, http://tonto.eia.doe.gov/ftproot/service/sroiaf(2007)05.pdf

13. FAO, State of the World's Forests 2007, Rome 2007, http://www.fao.org/docrep/009/a0773e/a0773e00.htm 
14. FAPRI, World Oilseeds and Products: 2008 Agricultural Outlook, April 2008, http://www.fapri.iastate.edu/

15. F.O.Licht, World Ethanol Markets, The Outlook to 2015, Kent, UK 2006

16. F.O.Licht and Agra Informa Ltd., World Biodiesel Markets, The Outlook to 2010, Kent UK, 2007

17. F.O.Licht, World Ethanol \& Biofuels Report, World ethanol production growth may slow down in 2008, October 2007

18. F.O.Licht, World Ethanol \& Biofuels Report, Sobering prospects - The world biodiesel production estimate, February 2008

19. Inter-American Development Bank, A Blueprint for Green Energy in the Americas, 2007, http://www.iadb.org/biofuels/

20. IEA, Biofuels for Transport - An International Perspective, Paris, April 2004

21. IEA, Statistics and Balances, Motor gasoline and diesel consumption, 2005, http://www.iea.org/Textbase/stats/index.asp

22. International Fund for Agricultural Development, February 2008, http://www.ifad.org/events/gc/31/roundtable/food.pdf

23. IMF, Indices of Primary Commodity Prices, 1998 - current (in terms of SDRs), Retrieved April 2008, http://www.imf.org/external/np/res/commod/index.asp

24. Industrial Technology Research Institute (ITRI), Chinese Taipei

25. Korea Energy Economics Institute (KEEI), http://www.keei.re.kr

26. Mitsubishi Gas Chemical Co., Inc (MGC), Brunei Darussalam Methanol Project, April 2007, http://www.mgc.co.jp/eng/news/2007/pdf/070412 e.pdf

27. National Development and Reform Commission (NDRC), China, http://en.ndrc.gov.cn/

28. National Renewable Energy Laboratory (NREL), Cost of Adding E85 Fueling Capability to Existing Gasoline Stations: NREL Survey and Literature Search, March 2008, http://www.eere.energy.gov/afdc/pdfs/42390.pdf

29. Palmas e Industrias del Espino, Peru

30. RSPO, Final principles and Criteria Document, October 2007, http://www.rspo.org/

31. Rural Industries Research and Development Corporation (RIRDC) and Commonwealth Scientific and Industrial Research Organization (CSIRO), Biofuels in Australia — issues and prospects, May 2007, http://www.rirdc.gov.au/reports/EFM/07-071.pdf

32. SENER-BID-GTZ, Potenciales y Viabilidad del Uso de Bioetanol y Biodiesel para el Transporte en México, November 2006, 
http://www.sener.gob.mx/webSener/res/169/Biocombustibles en Mexixo Estudio Com pleto.pdf

33. Tatsuji Koizumi, Keiji Ohga, Biofuels Polices in Asia: Trade effects on World Agricultural and Biofuels Trade, Presentation at the 2007 Agricultural Forum, Arlington, VA, March 2007, http://www.usda.gov/agency/oce/forum/2007\%20Speeches

34. Tripartite Task Force (Brazil, EU, and US), White paper on Internationally Compatible Biofuel Standards, December 2007, http://publicaa.ansi.org/sites/apdl/Documents/Meetings\%20and\%20Events/ANSI\%20Bio fuels $\% 20$ Standards $\% 20 \mathrm{Panel} /$ Tripartite $\% 20$ Task $\% 20 \mathrm{Force} \% 20$ Report/Internationally $\% 2$ 0Compatible\%20Biofuel\%20Standards.pdf

35. United Nations Conference on Trade and Development (UNCTAD), Commodity Price Statistics on-line, Retrieved April 2008, http://www.unctad.org/Templates/Page.asp?intltemID=1584\&lang=1

36. United Nations Economic Commission for Latin America and the Caribbean (UN ECLAC), http://www.eclac.cl/

37. USDA FAS, GAIN report, Peoples Republic of China Biofuels Annual, June 2007, http://www.fas.usda.gov/gainfiles/200706/146291348.pdf

38. USDA FAS, GAIN report, Russia Biofuels Annual, June 2007, http://www.fas.usda.gov/gainfiles/200706/146291296.pdf

39. USDA, FAS, Oilseeds: World Markets and Trade, March 2008, http://www.fas.usda.gov/oilseeds/circular/2008/March/oilseedsfull0308.pdf

40. Worldwatch Institute, Biofuels for Transport: Global potential and implications for sustainable energy and agriculture, Sterling, VA, 2007 


\section{Appendix A: Current Status of Biofuels Development in the APEC Region by Member Economy}

\section{Australia}

Australia's biofuels industry is in its early stage of development, with both ethanol and biodiesel making up its portfolio. The Australian Government has set a biofuels target of 350 million liters (ML) by 2010, however, this equates to less than one per cent of Australia's total transport fuel demand and at this level it will remain a niche industry with limited prospects (Wright, 2007).

The biofuels industry offers great opportunities for Australia's agriculture sector, but also some risks related to additional inputs (water, fertilizers, and pesticides), low crop production due to sustained drought conditions, and impact on other industries, such as livestock. A detailed riskbenefit assessment is needed if biofuels are going to play a stronger role in Australia's future transportation fuel mix.

Production. Ethanol production in Australia doubled in the past two years, from $40.3 \mathrm{ML}$ in 2005/06 to 83.6 ML in 2006/07. Biodiesel experienced a stronger growth during that period, from 21.2 ML to 76.3 ML. There were four operating ethanol plants as of November 2007 with a total capacity of $245.8 \mathrm{ML}$ per year. Current biodiesel production capacity is $246 \mathrm{ML}$ among the five existing plants. Additionally, Australian Renewable Fuels has two biodiesel plants with total capacity of $90 \mathrm{ML}$ and Australian Biodiesel Group also has two plants with $200 \mathrm{ML}$ capacity. However, these facilities are in care and maintenance mode as of November 2007.

Australia's Ethtec (Ethanol Technologies Limited), 51\% owned by Willmott Ltd., recently began work on an A $\$ 20$ million (US\$18 million) pilot cellulosic ethanol plant in New South Wales. The plant will use wood residues (including pine), bagasse and other lignocellulosic materials as feedstock and will convert it to ethanol via biochemical conversion process.

Feedstock. Ethanol in Australia is produced mainly from sorghum, wheat and sugar cane. Feedstock supply regions are the grain belt (primarily the South and Southeast) and the East coast, where the sugar cane is grown. Animal fats, used cooking oil and canola are used for biodiesel production in Australia. Alternative oilseed crops, such as pongam, jatropha, and Indian mustard have also been considered, particularly as candidates for marginal lands.

Major concerns for local ethanol producers are the rising cost of feedstock and irregular supply (due to persistent drought conditions). Drought has adversely affected grain and oilseed production in Australia for a second year in succession. Wheat production in 2007/08 is estimated at around 12.7 million tonnes, and canola production at 931000 tonnes. Although these production levels are significantly higher than production in 2006-07, they are well below average. The total area planted to grain sorghum is forecast to be 795000 hectares in 2007-08, 74 per cent more than the area sown last year. This is due to average and above average rainfall in the fall (ABARE, 2007).

\section{Economics.}

\begin{tabular}{|l|l|}
\hline Ethanol & US\$/liter \\
\hline From grains & 0.51 \\
\hline From C-molasses & 0.35 \\
\hline
\end{tabular}




\begin{tabular}{|c|c|}
\hline From suqar cane & 0.71 \\
\hline \multicolumn{2}{|l|}{ Source: RIRDC/CSIRO, 2007} \\
\hline Biodiesel & US\$/liter \\
\hline From used cooking oil & 0.31 \\
\hline From canola & 0.63 \\
\hline From tallow & 0.39 \\
\hline
\end{tabular}

Source: RIRDC/CSIRO, 2007

Biofuels in use. Ethanol and biodiesel are the two types of biofuels with commercial prospects in Australia. The bulk of biodiesel production is sold in blends with petroleum diesel; these blends range from B2 to B100. The bulk of ethanol production in Australia is sold in blends with petroleum containing up to $10 \%$ ethanol.

Infrastructure and Vehicles._Australia has over 800 biofuel refueling stations. The majority of these sell E10 with some stations selling biodiesel blends typically B2, B5 and B20. United Petroleum intends to sell E85 from two sites one in Melbourne and another in Sydney.

The Saab 9-5 2.3t was made available to Australian consumers in 2007. Accurate data on how many of these vehicles are now on road is not available; however an estimated 336 vehicles were sold as of June 2007.

Trade. Statistics on the trade of fuel ethanol are not available. However, small volumes of ethanol (all types - fuel, industrial, and beverage) were reported as been exported in 2006 to the Philippines; Japan; Malaysia; and Thailand.

Natural Fuels Australia Ltd. reported in August 2007 that made the economy's first export shipment of biodiesel for Asia and the US. The company produced 8.8 million liters of palm oil biodiesel annually.

Policy. The Australian Government promotes alternative fuels as a means of diversifying Australia's fuel mix and has in place a suite of measures to support alternative fuels and their use.

In total, the Government has committed over $\$ 200$ million to the development of Australian sources of biofuels. Relevant measures include:

- An election commitment in November 2007 to a $\$ 15$ million grant program into R\&D for second generation biofuel technologies;

- A biofuels target of at least 350 million litres by 2010. The measures to achieve this target include the Biofuels Action Plan, which indicate that biofuels will grow from a base of 28 million litres in 2005 to exceed the 350 million litre target by 2010;

- Initiatives to improve consumer confidence in ethanol including actively encouraging users of Commonwealth vehicles to purchase E10 (a blend of 10 per cent ethanol with petrol); undertaking vehicle testing of E5 (a blend of five per cent ethanol with petrol) and E10 blends; commissioning a study on the health impact of ethanol under Australian conditions; and labelling new Australian-made vehicles to advise of their suitability to use ethanolblended fuels;

- $\$ 37.6$ million for the Biofuels Capital Grants Program to support new or expanded biofuel production capacity; 
- The Ethanol Production Grant Program and the Cleaner Fuels Grant Program of 38.143 cents per litre paid to domestic ethanol and biodiesel producers respectively;

- Ensuring that alternative fuels remain effectively excise free until 2011, after which they will receive a 50 per cent discount on the rate of excise compared to other fuels with the same energy content;

- Funding of $\$ 7.72$ million committed under the National Collaborative Research Infrastructure Strategy to construct two pilot scale facilities for development of novel biofuel production technologies and to enhance related laboratory infrastructure at three universities;

- Funding of more than $\$ 7.5$ million for innovative renewable fuel projects under the Renewable Energy Development Initiative; and

- $\$ 17.2$ million for the Ethanol Distribution Program to support the uptake of ethanol by encouraging petrol stations to install new, or convert existing pumps, to sell E10 blended fuel.

\section{Sources:}

1. ABARE (Australian Bureau of Agricultural and Resource Economics), Report of the Biofuels Task Force to the Prime Minister, August 2005 http://www.grainscouncil.com/Policy/Biofuels/05 Sept 13 PM Biofuel Report.pdf

2. Biodiesel Association of Australia, http://www.biodiesel.org.au/

3. CSIRO, Biofuels in Australia - issues and prospects, May 2007, http://www.csiro.au/

4. Department of Resources, Energy and Tourism, http://www.directory.gov.au/index.php

5. Renewable Fuels Australia, http://www.renewablefuels.com.au/frameset.htm

6. Rural Industries Research and Development Corporation (RIRDC) and Commonwealth Scientific and Industrial Research Organization (CSIRO), Biofuels in Australia - issues and prospects, May 2007, http://www.rirdc.gov.au/reports/EFM/07-071.pdf

7. USDA Foreign Agricultural Service, GAIN Report - Australia Biofuels Annual 2006, June 2006, http://www.fas.usda.gov/gainfiles/200608/146208723.pdf

8. Wright, J., Biofuels in Australia - How Prospective?, ATSE Focus, Volume 146, September 2007, Energy 


\section{Brunei Darussalam}

Despite being a significant regional producer of oil and natural gas, Brunei Darussalam is looking into diversifying its energy portfolio and follows the global trend in search of alternative energy sources. At the 12th ASEAN Summit, held in Cebu, the Philippines, Brunei signed the energy pact "Cebu Declaration on East Asian Energy Security" which aims to reduce dependence on conventional fuels and accelerate the development of biofuels and other alternative energy.

A step forward in the outlined direction is the Memorandum of Understanding signed between Brunei Economic Development Board (BEDB) and HDZ Biodiesel Corporation Sdn Bhd (HDZ) in April 2007 to establish a biodiesel project in Brunei Darussalam. The agreement commits the BEDB and HDZ to jointly collaborate in the implementation of the Biodiesel Project in Brunei Darussalam. The project will involve the establishment of two biodiesel and glycerin production facilities with capacities of 100,000 tonnes per annum in Phase 1 and 400,000 tonnes per annum in Phase 2. The total investment by HDZ for the integrated biodiesel project is US\$263 million. HDZ is a Malaysian company established for the purpose of this project in Brunei Darussalam.

Currently, Brunei National Petroleum Company, or in short PetroleumBRUNEI, is in discussion with the Philippines National Oil Company-Alternative Fuels Corporation (PNOC-AFC) regarding a joint biodiesel project in the Philippines using jatropha as feedstock.

\section{Sources:}

1. Office of the Minister of Energy at the Prime Minister's Office, Energy Division, International Affairs Unit

2. The Brunei Economic Development Board (BEDB), www.bedb.com.bn/documents/PR-MOU Biodiesel 12-01-07.pdf 


\section{Canada}

Unlike some other economies, energy security is not a factor driving the biofuels development in Canada. Canada has the world's second largest proven oil reserves (estimated at 178,000 million barrels) and is one of the top ten oil-exporting countries in the world. However, Canada is committed to diversifying its energy portfolio with cleaner, renewable fuels such as ethanol and biodiesel.

Production. Ethanol production in Canada (all grades) was estimated at 569 million liters in 2006, with the potential to grow to 1,000 million liters in 2007 after new biorefineries come online. It is unknown what percentage of this production was dedicated to fuel use. However, previous studies estimated that fuel ethanol accounted for 2/3 of total ethanol production in 2005. The Canadian Renewable Fuels Association (CRFA) reports that there are ten existing ethanol plants (715 million liters total capacity) and six are under construction (880 million liters). The province of Ontario accounts for about half of Canada's ethanol production.

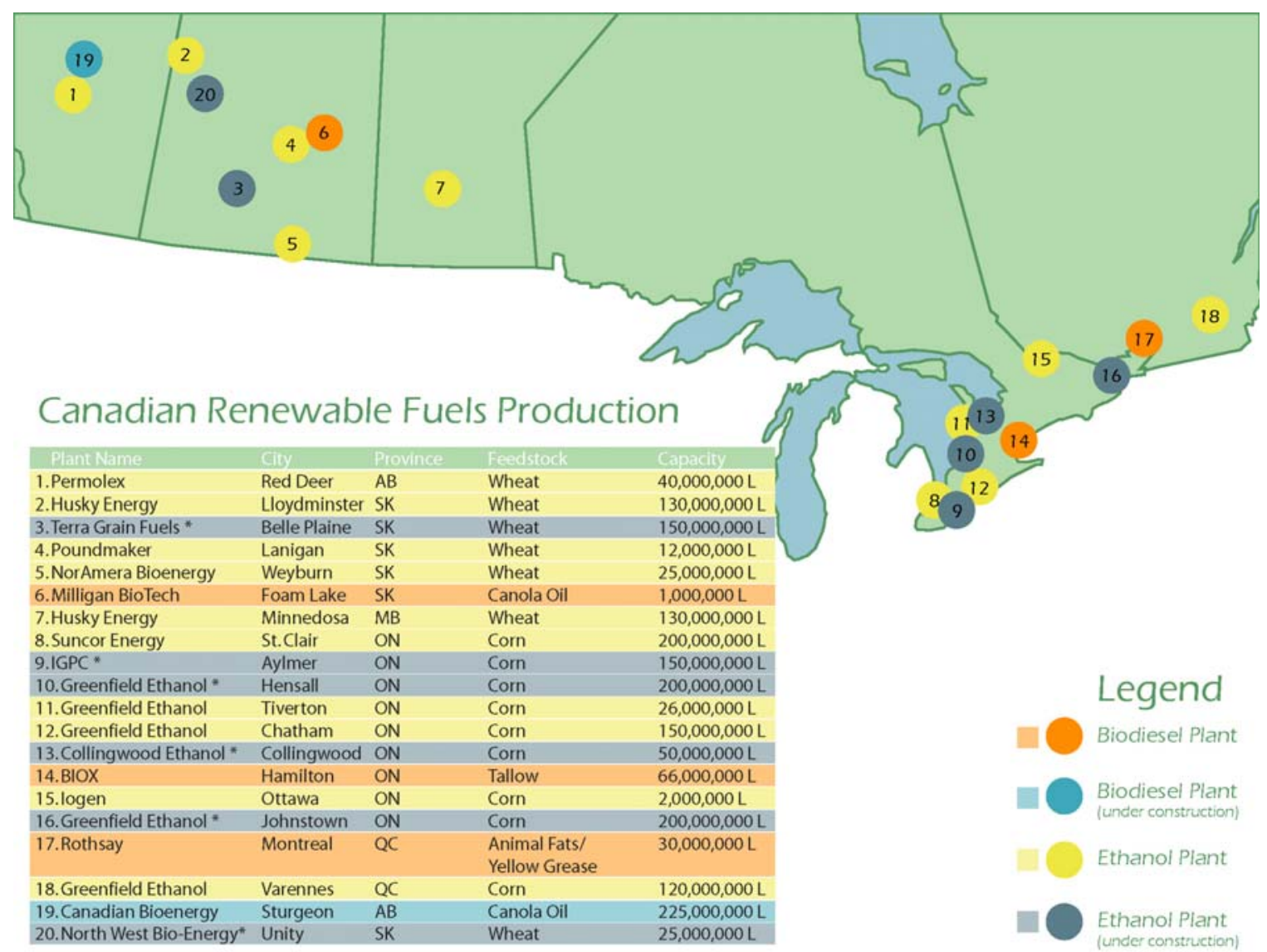

Source: Canadian Renewable Fuels Association

Figure 17 Biofuels Production in Canada

The company logen Corp. maintains a demonstration plant for producing ethanol from cellulose in Ottawa, but this plant produces demonstration, not commercial, quantities of cellulose ethanol. 
Production of biodiesel in Canada was estimated at about 47 million liters in 2006 . There are three existing production facilities with a total capacity of 96 million liters per year. Biodiesel Magazine reports one additional plant under construction in Arborg, Manitoba with 4 million liters capacity.

Feedstock. In Canada, ethanol is produced almost entirely from cereals (corn and wheat). Corn accounted for $77 \%$ of all ethanol feedstock in 2006 . This percentage is expected to lower due to more wheat based plants planned to come online in coming years (USDA). Corn production was about 9 million tonnes in 2006, $7 \%$ of which was used for ethanol production. The majority of domestically produced and imported corn is used by the livestock industry.

Wheat production in Canada is much higher, more than 20 million tonnes annually. Being the world's second largest exporter of wheat, after the USA, the majority of this production goes for export (about 17 million tonnes annually). Less than 1\% was used for ethanol production in 2006.

With its vast forest and agricultural resources, Canada has a great potential for cellulosic ethanol production. In the agricultural sector, prairie grain crops produce an estimated 32 million tonnes of straw residue per year. If $85 \%$ of that straw must be put back into the soil to maintain fertility, approximately 5 million tonnes would be available to make biofuel. Canada has millions of hectares of managed forests and much of the forest residue is not used and is sent to a landfill or is incinerated.

Biodiesel in Canada is produced from animal fats, recycled cooking oils, and canola. The Canadian rendering industry produces about 400,000 tonnes of animal and yellow grease annually for the oleochemical and animal feed industry. Canola is Canada's dominant vegetable oil (grown annually on approximately 13 million acres) and the sheer size of the annual crop makes it easy to supply the biofuel market. Currently, about 80 per cent of Canada's annual canola production is exported. About 1 million tonnes of canola would be needed to meet the $2 \%$ biodiesel target set by the government. Last year alone the industry's carry-over or unsold volumes that stayed in storage bins was 1.5 million tonnes. However, rising feedstock prices are of concern for the biodiesel industry. Canola is priced high being oil for human consumption, while yellow grease and animal fats are priced as residual oils for feed and industrial use.

Estimates by the Canadian Canola Growers Association show a potential of 500 million liters of biodiesel in the 2007 - 2010 time frame. This potential is broken down as follow: 160 million liters from tallow, 80 million liters from yellow grease, 220 million liters from canola, and 40 million liters from soybeans ${ }^{11}$.

\section{Economics.}

\begin{tabular}{|l|l|}
\hline Ethanol & CAN\$/liter \\
\hline From grains & $0.36-0.46$ \\
\hline \multicolumn{2}{|l}{ Source: Canadian Renewable Fuels Association, 2006}
\end{tabular}

\begin{tabular}{|l|l|}
\hline Biodiesel & CAN\$/liter \\
\hline From yellow grease & 0.48 \\
\hline From tallow & 0.61
\end{tabular}

${ }^{11}$ Biodiesel density: $0.85-0.88 \mathrm{gr} / \mathrm{cm} 3$ 
From canola oil

0.81

Source: Canadian Canola Growers Association, 2006

Biofuels in use. E5 is sold in Ontario, E7.5 in Saskatchewan, and E8.5 in Manitoba. E85 is mostly used by the fleets of Natural Resources Canada (NRC).

Biodiesel in low blends (B2 and B5) has been used by government and private fleets all across Canada. B20 is used by Terminal Systems Inc., the largest container terminal operator in Canada, in all equipment and vehicles with diesel engines.

Infrastructure and Vehicles. In Canada, there are currently about 1,000 service stations offering ethanol blended gasoline at blends varying from 5 to 10 percent ethanol, depending on the retailer and provincial requirements.

UPI Energy opened the first E85 retail pumps in Canada in 2007, one in Guelph, Ontario, and another in Chatham, Ontario. NRC has one of the few private E85 refueling stations feeding a fleet of departmental cars.

No statistics are available on the number of Flexible Fuel Vehicles (FFVs) on the roads in Canada.

Trade. There is no official data available for either fuel ethanol or biodiesel trade. However, statistics show that Canada imported about 100 million liters of ethanol (all grades - potable and denatured) in 2006, exclusively from the US. Several Canadian companies import biodiesel from the US as well.

Under NAFTA there is a free trade of renewable fuels between United States; Mexico; and Canada. However, Canada does have a tariff on ethanol imported from Brazil (CAN\$0.05 per liter).

Policy. In July 2007, the Canadian government announced that it would provide up to CAN $\$ 1,500$ million in the form of incentives over nine years to producers of renewable alternatives to gasoline and diesel fuel. The incentives are primarily for producers, to "bridge the gap" between the current production level and the 3,000 million tonnes/year that will be needed to meet the 2012 targets set by the government in December 2006 when it announced a new energy policy. Essential elements of the new policy include:

- Reaching an average of $5 \%$ renewable content in gasoline by 2010 and $2 \%$ renewable content in diesel fuel and heating oil by 2012.

- Federal incentives are currently provided through excise tax exemptions amounting to $\$ 0.10$ per liter for ethanol and $\$ 0.04$ per liter for biodiesel.

- National Biomass Expansion Program provides for $\$ 140$ million in contingent loan guarantees to encourage financing for new plants that produce ethanol from biomass material such as crop residues.

\section{Government Programs:}

The eco Agriculture Biofuels Capital Initiative (ecoABC) is a federal $\$ 200$ million four-year capital grant program that provides funding for the construction or expansion of transportation biofuel production facilities. It appears funding is focused on cellulosic ethanol. 
On July 5, 2007, Prime Minister Stephen Harper announced the ecoENERGY for Biofuels Initiative, which will invest up to CAN\$1,500 million over 9 years to boost Canada's production of biofuels.

The ecoAUTO Rebate Program encourages Canadians to buy fuel-efficient vehicles, including FFVs. It offers rebates from $\$ 1000$ to $\$ 2000$, to people who, beginning March 20, 2007, buy or enter a long-term lease (12 months or more) for a fuel-efficient vehicle.

Several Canadian provinces have additional policies and incentives:

- Ontario's regulation requires an average of $5 \%$ ethanol in gasoline and went into effect in January 2007; Ontario announced in June 2006 that it was phasing out its road tax exemption and replacing it with the Ethanol Growth Fund intended to provide ethanol production incentives of $\$ 520$ million over 12 years.

- Saskatchewan's 7.5\% ethanol requirement in gasoline took effect in October 2006; Saskatchewan also offers a distributor tax credit for ethanol of up to $\$ 0.15$ per liter, provided that ethanol is produced and consumed in the province.

- Manitoba has passed legislation requiring $10 \%$ ethanol content in $85 \%$ of the province's fuel, but has not yet set a date for entry into force; Manitoba offers a provincial tax credit of $\$ 0.25$ per liter for fuels containing at least $10 \%$ ethanol (provided the fuel is produced and consumed in Manitoba), as well as a $\$ 0.115$ per liter tax exemption for biodiesel.

- Quebec has set a goal of 5\% ethanol in gasoline by 2012 and expects that target to be met by next-generation cellulosic ethanol; Quebec provides an income tax credit for ethanol producers that both produce and sell in Quebec. Quebec also offers reimbursement of fuel taxes paid on the purchase of biodiesel.

- British Columbia has road tax exemptions for ethanol and biodiesel of $\$ 0.145$ and $\$ 0.150$ per liter respectively. The BC Energy Plan, announced in August 2007, will implement a five per cent average renewable fuel standard for diesel by 2010 and will increase the ethanol content of gasoline to five per cent by 2010.

- Alberta announced a Bio-Energy Program in October 2006 that replaced its provincial ethanol road tax exemption and allocates $\$ 209$ million over four years to renewable fuels and $\$ 30$ million for commercialization support. It includes a BioEnergy Producer Credit program, a Bio-Refining Commercialization and Market Development Program, and the Bio-energy Infrastructure Development Program.

\section{Sources:}

1. Natural Resources Canada, http://www.nrcan.gc.ca/com/index-eng.php

2. Canadian Canola Growers Association, http://www.ccga.ca/

3. Canadian Renewable Fuels Association, http://www.greenfuels.org/

4. Canola Council of Canada, http://www.canola-council.org/

5. Biodiesel Association of Canada, http://www.biodiesel-canada.org/

6. Transport Canada, http://www.tc.gc.ca

7. The Office of Energy Efficiency (OEE), http://oee.nrcan.gc.ca/

8. Biodiesel Magazine, http://www.biodieselmagazine.com/

9. Ethanol Producer Magazine, http://www.ethanolproducer.com/

10. USDA, GAIN Report 2007, http://www.fas.usda.gov/gainfiles/200708/146292128.pdf 


\section{Chile}

Biofuels are receiving increasing attention in Chile driven primarily by the desire to reduce dependence on imported fossil fuels. At present, Chile imports 72 percent of its fuel as oil, gas and coal. Chile also hopes to alleviate serious air pollution problems in the capital and promote agricultural development through alternative fuels.

Currently, there is no production or consumption of biofuels in Chile. According to the government's preliminary estimates, there are 170,000 hectares in Chile that could be farmed to produce the raw materials for biodiesel and ethanol. An introduction of E10 in Chile would require 142,000 ha of arable land and 616,000 ha for B10 (ECLAC, 2007).

Chile produces corn, wheat, and sugar beet, all of which are potential feedstock for ethanol. However, given the limited land available in Chile and the current need to import significant quantities of food, second generation biofuels, particularly from forestry resources, appear to be more promising. Rapeseed is the likely candidate for biodiesel production. Today, Chile has approximately 40,000 ha of land dedicated to rapeseed production, enough to cover a supply for B2 (ECLAC, 2007). Jatropha, algae, and animal fat are also mentioned as possible biodiesel feedstock. The University of Tarapaca has planted 1,500 ha of jatropha as a pilot project.

Given the economics for ethanol production (ECLAC, 2007) from corn - US $\$ 0.80 /$ liter, from sugar beet - US\$0.90/liter, and from wheat - US\$0.92/liter, it is unclear whether or not Chile would be better off importing biofuels from its neighbors and if the domestic production of biofuels should be subsidized.

The Chilean government seems determined to develop a biofuels industry. The Ministry of Agriculture recently devoted $\$ 1$ million to study the optimal feedstock for a biofuels industry. This effort has not yet yielded definitive conclusions, but it is the first significant sign of government interest. The Ministry of Agriculture and the Ministry of Mines and Energy have joined forces to assess the potential for a sustainable industry. In addition, the Chilean government passed a Renewable Law, but it will require considerable elaboration before it can become a viable blueprint for development of the industry (IADB). The government plans to introduce voluntary E5 and B5 in 2008 as part of a trail program. The blending will occur at refineries, such as ENAP - the National Oil Company of Chile or at point of distribution, such as Copec, which holds $50 \%$ of the market (ECLAC).

\section{Sources:}

1. Inter-American Development Bank (IADB), A Blueprint for Green Energy in the Americas, 2007, http://www.iadb.org/biofuels/

2. Natural Resources and Infrastructure Division, United Nations Economic Commission for Latin America and the Caribbean (UN ECLAC), 2007 http://www.fia.gob.cl/difus/Manlio Coviello.pdf 


\section{China}

China's economic growth in the 1990s resulted in a rapid increase of petroleum consumption and led to serious air pollution problems. To deal with fuel shortage, energy security and air quality issues, the Chinese government began promoting biofuels in 2000. However, concerns about feeding the world's most populous nation could limit the growth of China's biofuels industry. China has long been concerned about its food security, thus the top priority for land use is and most likely will remain food crops.

Production. China is the world's third largest producer of ethanol, but most of it is consumed by the pharmaceutical and beverage industries. In 2006, there were four operating ethanol biorefineries (Figure 18) running at maximum capacity, about 1.02 million tonnes. Though Beijing has stopped approving new fuel ethanol projects since December 2006, four more plants in the provinces of Guangxi (110,000 tonnes), Hebei (300,000 tonnes), Liaoning $(300,000$ tonnes), and Hubei $\left(200,000\right.$ tonnes) were scheduled to be completed in $2007^{12}$.

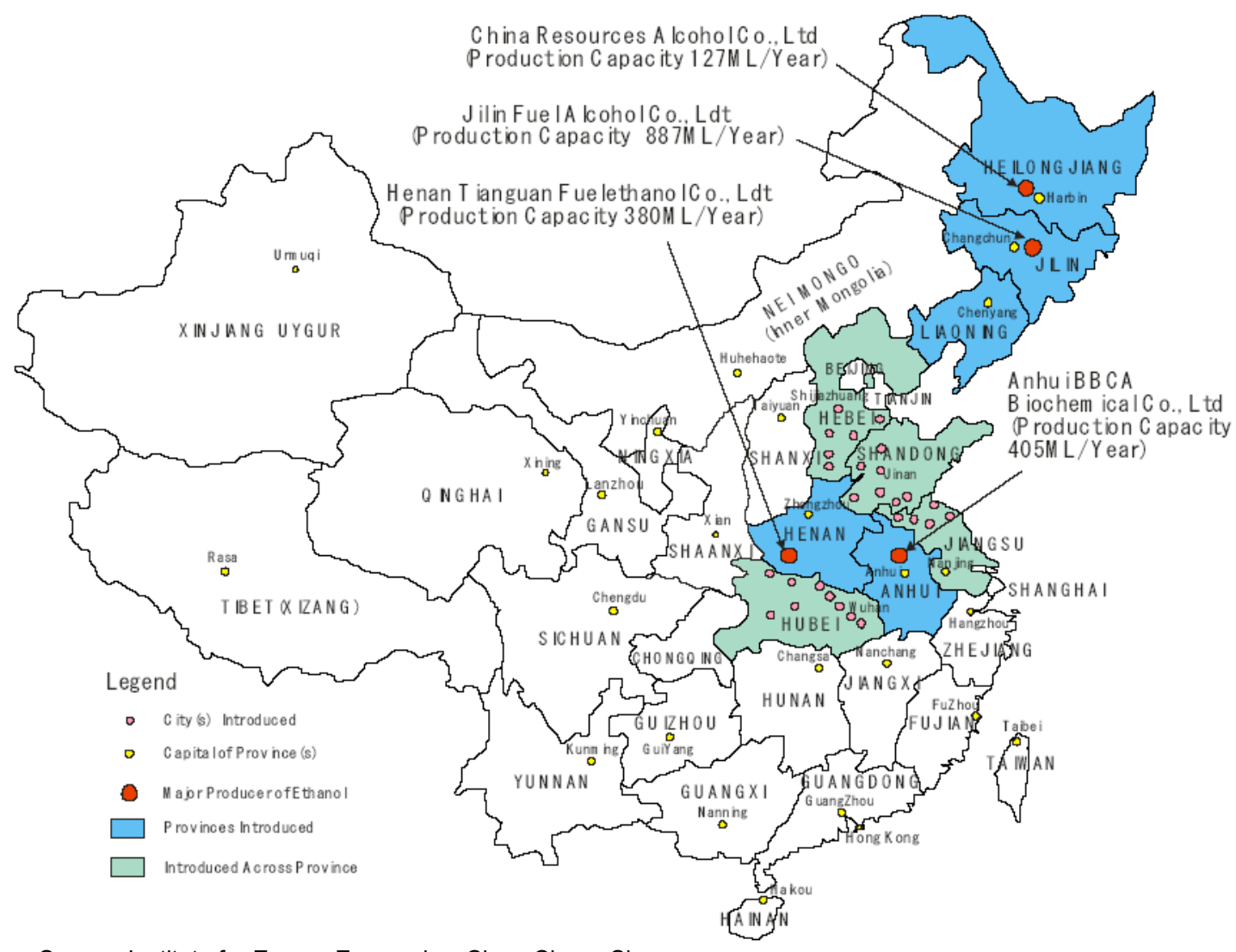

Source: Institute for Energy Economics, Chew Chong Siang

Figure 18 Ethanol Producers and Areas with E10 Consumption in China

China National Cereals, Oils and Foodstuffs Corp. (COFCO) is investing 50 million Yuan (US\$6.5 million) in building a cellulosic ethanol pilot plant. The plant in Zhaodong in the

${ }^{12}$ Ethanol density: $0.79 \mathrm{gr} / \mathrm{cm} 3$ 
northeastern province of Heilongjiang will have an annual capacity of 5,000 tonnes. Another cellulosic ethanol pilot plant with a production capacity of 10,000 tonnes is being planned in Yucheng area of Shandong.

Biodiesel is in its early development stage in China. In 2006 biodiesel production was 30,000 tonnes from a dozen of small-scale production facilities. Principal biodiesel producers are Fujian Zuoyue New Energy Co.Ltd, Sichuan Gusan Biodiesel Co. Ltd, and Hainan Zhenghe Biodiesel Co.Ltd. Since 2006 biodiesel plants have opened in Shanghai, Fujian, Jiangsu, Anhui, Chongqing, Xinjiang and Guizhou, among other places, in the form of private, state-owned and even foreign-owned enterprises. New plants are much larger than the existing ones, some reaching 600,000 - 750,000 tonnes/year. Dozens of biodiesel projects are under construction or in planning with cumulative capacity of more than 3 million tonnes/year.

Feedstock. Nearly $80 \%$ of the fuel ethanol in China is made from corn. Three of the existing facilities (Heilongjiang, Jilin, and Anhui) use the grain as feedstock. The biorefinery in Henan uses wheat. Concerns about food supply and high prices led the industry to look at other, nongrain feedstock, such as cassava, sweet sorghum and sweet potato, viewed as transitional feedstock in a long term. The crops could be grown on China's 116 million hectares of marginal land unsuitable for producing grains. Ultimately, China plans to transition to ethanol production from lignocellulosic biomass, particularly crop residues, which are of sufficient supply. Estimates show that the economy generates approximately 1,500 million tonnes/year of agricultural and forest residues, which is sufficient to produce 370 million tonnes of ethanol. Currently, there are several pilot plants producing ethanol from lignocellulosic biomass via biochemical conversion process.

Feedstock supply is a key factor in limiting biodiesel development in China. Vegetable oils are main feedstock for plants elsewhere. However, it is not economical for China to import them to make biodiesel since it already imports significant amounts for food consumption. The existing feedstock is used cooking oil, acid oil and animal fat. A lot of waste oil and grease are produced from food processing industry due to cooking habits. It is estimated that about 3 million tonnes of waste oil and grease are produced in China annually. For a long term development of biodiesel China is considering non-edible feedstock, such as Barbados nut (Jatropha Curcas), Chinese pistachio (Pistacia Chinensis), Chinese tallow tree (Sapium Sebiferum), etc. Jatropha is abundant in Southwest China (Sichuan, Yunnan, Guizhou, etc.) with potential for planting in large scale and good economic and social benefits. However, this area also contains ecologically sensitive and biodiverse forest area, thus careful considerations should be made in policy decisions.

\section{Economics.}

\begin{tabular}{|l|l|}
\hline Ethanol & RMB/tonne \\
\hline From corn & 5,000 \\
\hline From sweet sorghum & 4,000 \\
\hline From cassava/sweet potato & 4,500 \\
\hline Source: NDRC, 2007
\end{tabular}

\begin{tabular}{|l|l|}
\hline Biodiesel & RMB/tonne \\
\hline From used cooking oil & 4,000 \\
\hline Source: NDRC, 2007 &
\end{tabular}


Biofuels in use. E10 is used in five provinces: Helongjiang, Jilin, Liaoning, Henan, Anhui, and 27 cities: 9 in Hubei, 7 in Shandong, 6 in Hebei, and 5 in Jiangsu (Figure 18). Gasohol consumption in 2005 accounted for nearly $20 \%$ of national gasoline consumption.

According to a USDA report, biodiesel currently produced in China is of low quality, and it is not suitable for fuel use. It has been used as a solvent or as an additive to coal in thermal power plants or industrial cooking facilities in rural areas.

Infrastructure and Vehicles. There are 75,000-85,000 refueling stations in China, with approximately 20,000 offering E10.

Trade. China exports mostly potable ethanol, particularly towards Japan; Korea; and Singapore where it is used for alcohol production. In 2006 China hit a record volume of export, about 500,000 tonnes. This was mostly due to higher demand in the US (phasing out MTBE) which increased the price of alcohol.

Official statistics on biodiesel trade is not available, but estimates show that total exports were approximately 10,000 tonnes in 2006 (USDA). Some attempts were made to import palm oil from Indonesia and Malaysia, but they have been suspended due to rising prices of this feedstock.

Policy. In 2001 State Council launched a Fuel Ethanol Program, which led to the establishment of the four ethanol plants and distribution of E10 in 9 provinces. Polices, such as free income tax, VAT refunding, and fiscal subsidies were made available to the ethanol producers. In 2006 each ton of ethanol received a 1,373 Yuan subsidy. Beijing has committed 1,100 million Yuan (US\$143 million) to help develop vehicles that run on biofuels. In comparison, policy measures for the biodiesel industry are not developed. Technical standards, distribution channels, production techniques, equipment, environmental evaluations, etc. are yet to be finalized.

Under the revised National Plan fuel ethanol production is to rise to 3 million tonnes/year by 2010 and to 10 million tonnes/year by 2020 . Biodiesel is to grow to 300,000 tonnes/year in 2010 and 2 million tonnes/year in 2020. According to the Plan, E10 sales are to expand in more provinces in 2010, and possibly introducing E20 and E85, as well as B5 or B10 in 2020.

The Chinese government overall policy in respect to biofuels is to move this technology forward in a way that it doesn't compete with arable land, grain is not used as feedstock, and it doesn't destroy the environment. No new corn based ethanol plant is to be approved. It considers giving subsidies and tax breaks to demonstration projects: plants using non-grain feedstock and plantations growing non-food crops.

\section{Sources:}

1. The National Development and Reform Commission (NDRC), http://en.ndrc.gov.cn/

2. US Department of Agriculture, GAIN Report 2007, http://www.fas.usda.gov/gainfiles/200706/146291348.pdf

3. Institute for Energy Economics, Japan, http://eneken.ieej.or.jp/en/ 


\section{Hong Kong, China}

Rapid urbanization in the past two decades had led to serious air pollution problems, with motor vehicle emissions being one of the most pressing one. To cope with the situation, the Government of Hong Kong has adopted many programs and measures focused on improving the fuel quality and efficiency, such as Liquefied Petroleum Gas (LPG) taxis and minibus programs, installation of particulate trap and oxidation catalytic converter, and introduction of ultra low sulfur diesel. To relief existing pollution, biofuels, and biodiesel in particular, have also being considered in recent years.

Biodiesel feedstocks available in Hong Kong are waste cooking oil and animal fats. About 10,000 liters of used cooking oil are produced everyday in Hong Kong, which translates roughly into 3.5 million liters of biodiesel per year. There is one existing biodiesel production plant in Hong Kong, with a small output primarily for domestic consumption (annual capacity of 4.3 million liters). A second plant is to be build by the ASB Biodiesel, a joint venture company, near the Tseung Kwan $\mathrm{O}$ industrial area of Hong Kong. The plant will have a capacity of about 114 million liters (100,000 tonnes) per year and it will utilize waste products including used cooking oil, waste animal fat and grease trap waste (restaurant sewage). The biodiesel produced will be for domestic consumption and export to Europe.

Hong Kong based companies have invested in ethanol production projects in other parts of the world, such as Noble Group Ltd. in Brazil and Rapid Grow Investments in Fiji.

The Government of Hong Kong encourages the use of biodiesel and plans to introduce a dutyfree policy on its use. The Environmental Protection Department is drawing up specifications for biodiesel to ensure fuel quality, boost user's confidence and help control the impact on environment. The Government will further propose a mandatory labeling requirement for biodiesel blends above $5 \%$ to ensure their proper use in vehicles and increase awareness of some possible corrosion problems associated with higher blends.

\section{Sources:}

1. Electrical and Mechanical Service Department (EMSD), The Government of the Hong Kong Special Administrative Region; http://www.emsd.gov.hk

2. Koo, B.C.P. and Leung, D.Y.C., Emission Testing on a Biodiesel Produced from Waste Animal Fats, Proceedings of the Third Asia-Pacific Conference on Sustainable Energy and Environmental Technologies, 2000 


\section{Indonesia}

Indonesia sees biofuels as one of the key instruments to accelerate economic growth, alleviate poverty, and create employment opportunities while at the same time under the Kyoto Protocol mitigate greenhouse gas emissions. The government had set up goals of reaching $2 \%$ biofuels in the energy mix by 2010 (5.29 million kiloliters), growing to 3\% by 2015 (9.84 million kiloliters) and $5 \%$ by 2025 (22.26 million kiloliters). Major challenge to achieving these goals is financing and the government has provided a set of incentives to attract domestic and foreign investors. The government prohibits rainforest deforestation for biofuels purposes.

Production. Ethanol production in Indonesia was about 140 million liters in 2007 and the economy plans to reach 3,770 million liters in 2010 (Figure 19). Biodiesel production in 2007 was about 1,550 million liters and it is estimated to reach 5,570 million liters in 2010 (Figure 20).

\section{Bio-ethanol: Production plan up to 2010 (+/- 3.77 million KL/year)}

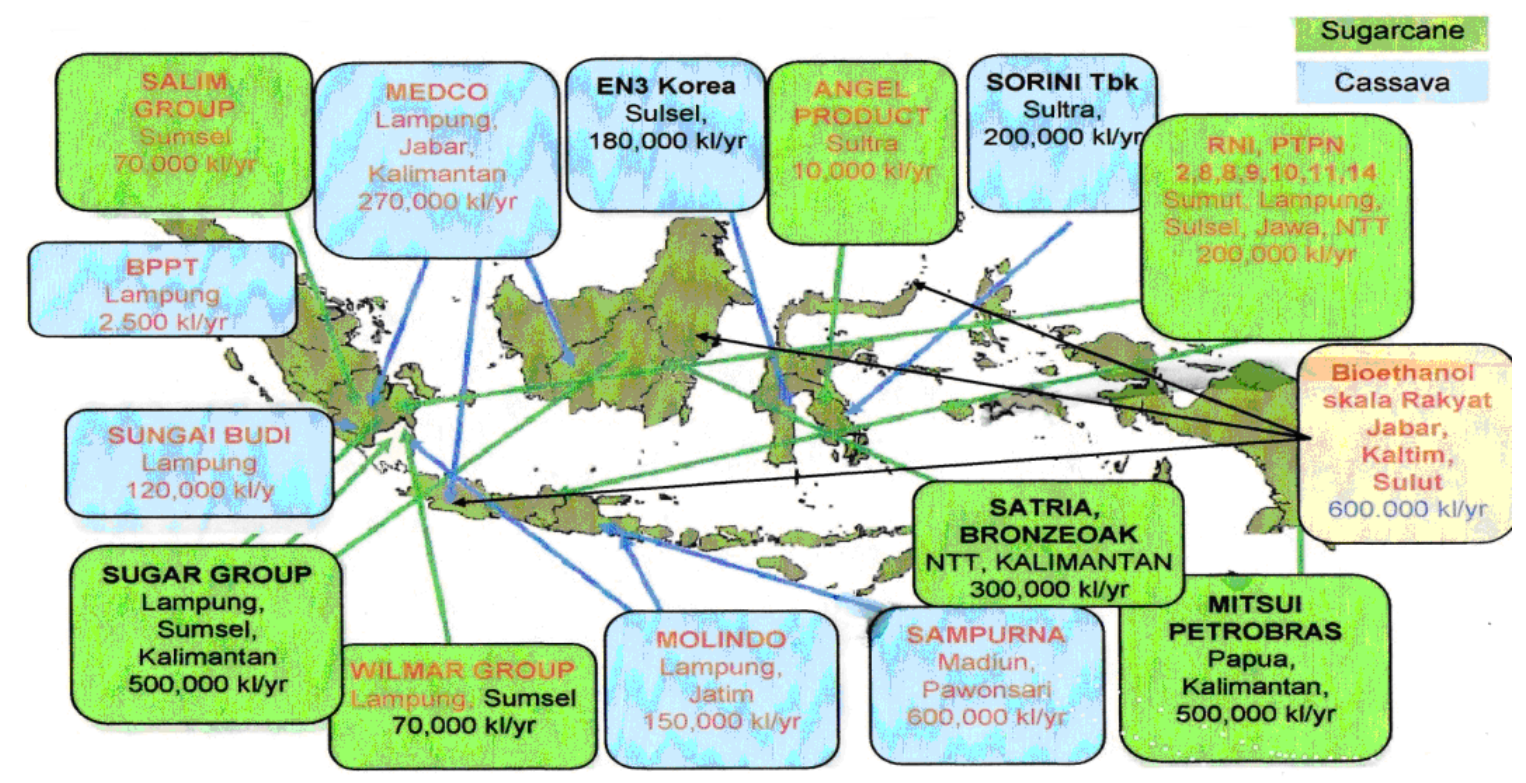

Source: Indonesia National Biofuels Team, 2008

Figure 19 Planned Ethanol Production Facilities in Indonesia 
Bio-diesel: Production plan up to 2010

(+/- 5.57 million KL/year)

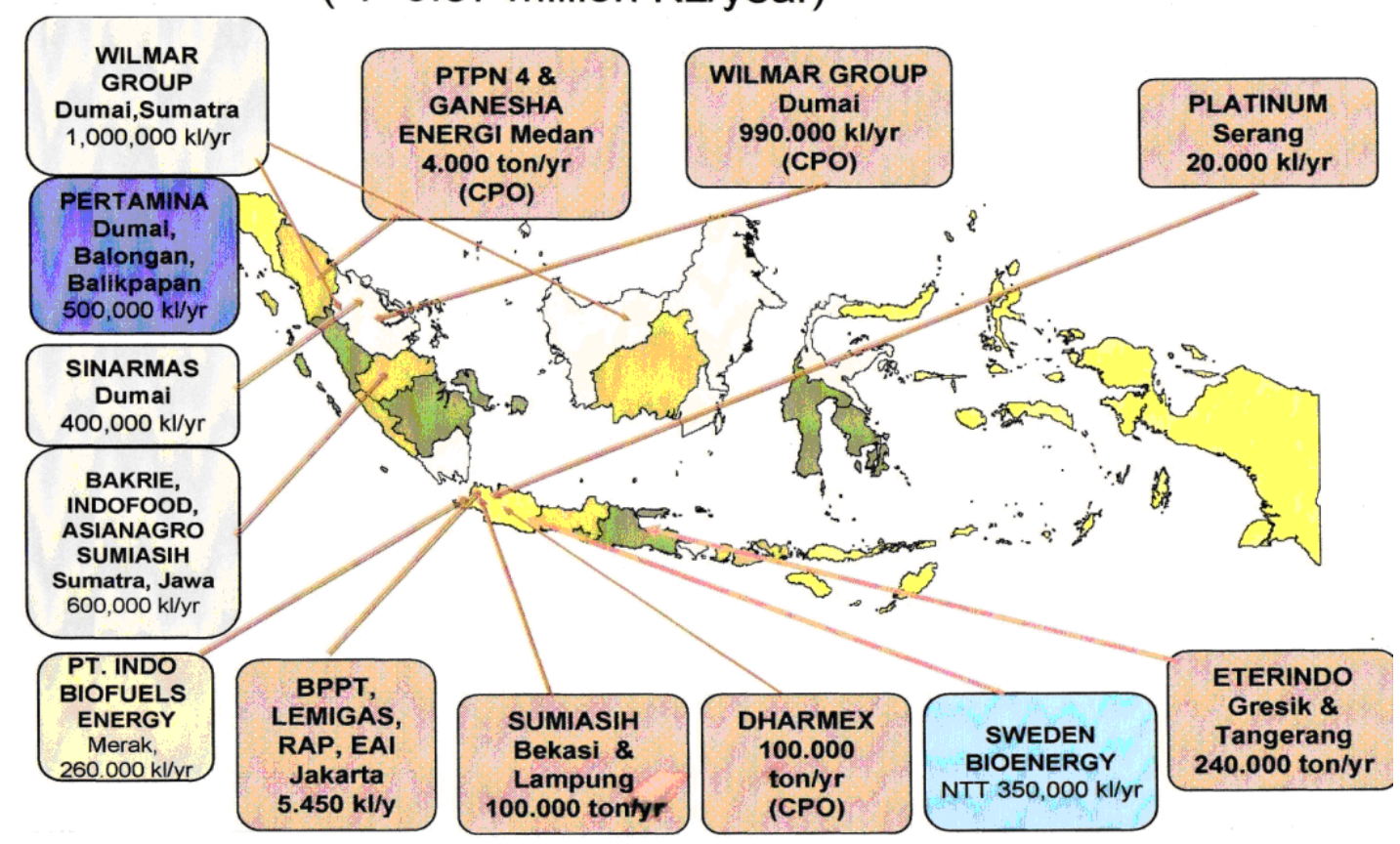

Source: Indonesia National Biofuels Team, 2008

Figure 20 Planned Biodiesel Production Facilities in Indonesia

Feedstock. The main biodiesel feedstock in Indonesia is crude palm oil (CPO) due to the well established CPO industry and potential for the increase in production. Indonesia surpassed Malaysia in palm oil production in 2007 and is now the world leader. Together, Indonesia and Malaysia provide $87 \%$ of the world's palm oil. Indonesia's CPO output is estimated to be 17.4 million tonnes in 2007, up from 15.9 million tonnes in 2006. There are 6 million ha of oil-palm plantations. The government established laws and regulations guiding their expansions in order to prevent deforestation.

Other potential biodiesel feedstocks in Indonesia include coconut oil and jatropha. In 2006 Indonesia's coconut oil production was around 880,000 tonnes, with between 450,000 and 550,000 used for export purposes. Jatropha is still in the very early stage of development and there are concerns that it is not feasible for large-scale production. At least two companies are making serious preparations to use jatropha as a feedstock. Though using jatropha would remove the conflict between food and fuel, jatropha is more labor-intensive and produces less oil than oil palm. At this time, Indonesian government efforts appear to be focused on using jatropha in villages where electricity is not cost-effective (USDA). The government plans to provide them with processing machineries.

Currently, fuel ethanol in Indonesia is produced from sugarcane molasses. Indonesia has about 5.5 million acres dedicated to sugarcane production, and several companies want to expand their plantations. Indonesia is among top 10 sugarcane producers in the world with about 30 million tonnes per year. Indonesia is also looking at cassava as feedstock for ethanol. There were 52,195 ha planted with cassava in 2007 and it is expected to increase to 782,000 ha. In 
Indonesia, 1 ton of molasses yields about 250 liters of ethanol and 1 ton of cassava yields about 155 liters (USDA).

Due to abundant biomass resources, such as palm fruit shells, rice husk, sugarcane bagasse, and other crop and forest residues, Indonesia is very interested in cellulosic ethanol production and actively supports R\&D in the area.

\section{Economics.}

\begin{tabular}{|l|l|}
\hline Biodiesel & US\$/liter \\
\hline From palm oil & 0.41 \\
\hline From jatropha & 0.48 \\
\hline
\end{tabular}

Source: APEC Biofuels Task Force, 2007

Biofuels in use. B5 (Bio-solar) and E5 (Bio-pertamax) are available through the state-owned oil firm Pertamina. In January 2008, Pertamina reduced the percentage of biofuels in its Biosolar and Biopertamax products from $5 \%$ to $2.5 \%$ due to rising palm oil prices and lack of incentives.

Infrastructure and Vehicles. B5 is offered at 228 gas stations in Jakarta, Surabaya, and Bali. Since December 2006, E5 is offered at 14 stations in Jakarta, 7 in Surabaya, 4 gas in Malang, and 11 in Bali. Bio-premium (E5 using Premium blend) is offered at 1 station in Malang.

Trade. While Indonesia exports small amounts of biodiesel to China; EU; and the United States, CPO remains the main trading commodity. The Indonesian Palm Oil Producers Association estimates that Indonesia's palm oil exports were slowing down in 2007, mainly because of the growth in domestic biodiesel consumption. Exports reached 12.1 million tonnes in 2006, and it is estimated at 13.1 to 13.2 million tonnes in 2007. If palm oil production in Indonesia reaches more than 18 million tonnes in 2008, exports may be around 14 million tonnes, but it will also depend on the growth of the biodiesel industry (Pacific Biofuel).

The main export market for Indonesian ethanol is Japan. The future of ethanol export is uncertain, considering the growth of domestic fuel ethanol demand.

\section{Policy.}

- Presidential Instruction No.1/2006 to 13 central and regional government institutions on supply and utilization of biofuels as alternative energy (January, 2006)

- Presidential Decree No.5/2006 on National Energy Policy, calling for $5 \%$ biofuels in the energy mix by 2025 (January, 2006)

- Presidential Decree No.10/2006 established the National Team for Biofuels Development to coordinate the industry expansion (July, 2006)

While the Indonesian government had expressed strong interest in the biofuels development, it has been moving slowly and cautiously in implementing supporting policy. The government subsidizes biodiesel, bio-premium, and bio-pertamax at the same level as fossil fuels, leaving Pertamina to cover the difference when biodiesel production costs exceed fossil fuel costs. The government is considering providing various incentives, including value-added tax (VAT) reductions for business players, and excise duty cuts for biofuels users. In 2007 the government announced interest rate subsidy of Rp 1 trillion for farmers growing biofuels crops including jatropha, oil palm, cassava and sugar cane. 


\section{Sources:}

1. Indonesia National Biofuels Team, April 2008, http://www.biofuelindonesia.com/index.html

2. Ministry of Energy and Mineral Resources (MEMR), presentation given at the USDA Global Conference on Agricultural Biofuels Research and Economic, Minneapolis, Minnesota, August 2007, http://www.ars.usda.gov/meetings/Biofuel2007/presentations/IP-B/Kussuryani.pdf

3. Pacific Biofuel, August 2007, http://pacbiofuel.blogspot.com/2007/08/pbn-indonesiasees-slower-palm-oil.html

4. US Department of Agriculture, GAIN Report, 2007, http://www.fas.usda.gov/gainfiles/200706/146291372.pdf

5. APEC Biofuels Task Force (BTF) Report to the Eight Energy Ministers, 2007 http://www.ewg.apec.org/assets/documents/apecinternet/Biofuelsreport\%5FEMM820 $\underline{071011104537 \% 2 E p d f}$ 


\section{Japan}

Rising oil prices and global warming prevention are the key drivers in Japan's biofuels campaign. Biofuels are also seen as an opportunity for business development and vitalization of rural and farming communities. The government strongly supports the development of innovative technologies for low-cost fuel ethanol.

Production and Feedstock. Japanese fuel ethanol production is in an experimental stage, and the current production level is 30,000 liters (April 2006). Figure 21 depicts the location of the existing biorefineries. Sugarcane molasses (Okinawa), wheat and corn unsuitable for food (Hokkaido), sorghum (Yamagata), and wood residues (Okayama and Osaka) are the raw materials currently used for ethanol production. To further promote domestic ethanol production, the government hopes to utilize abandoned arable land (Koizumi and Ohga, 2007). It will also rely on technological breakthrough in cellulosic ethanol in the near future, which would allow the use of waste material such as crop and wood residues.

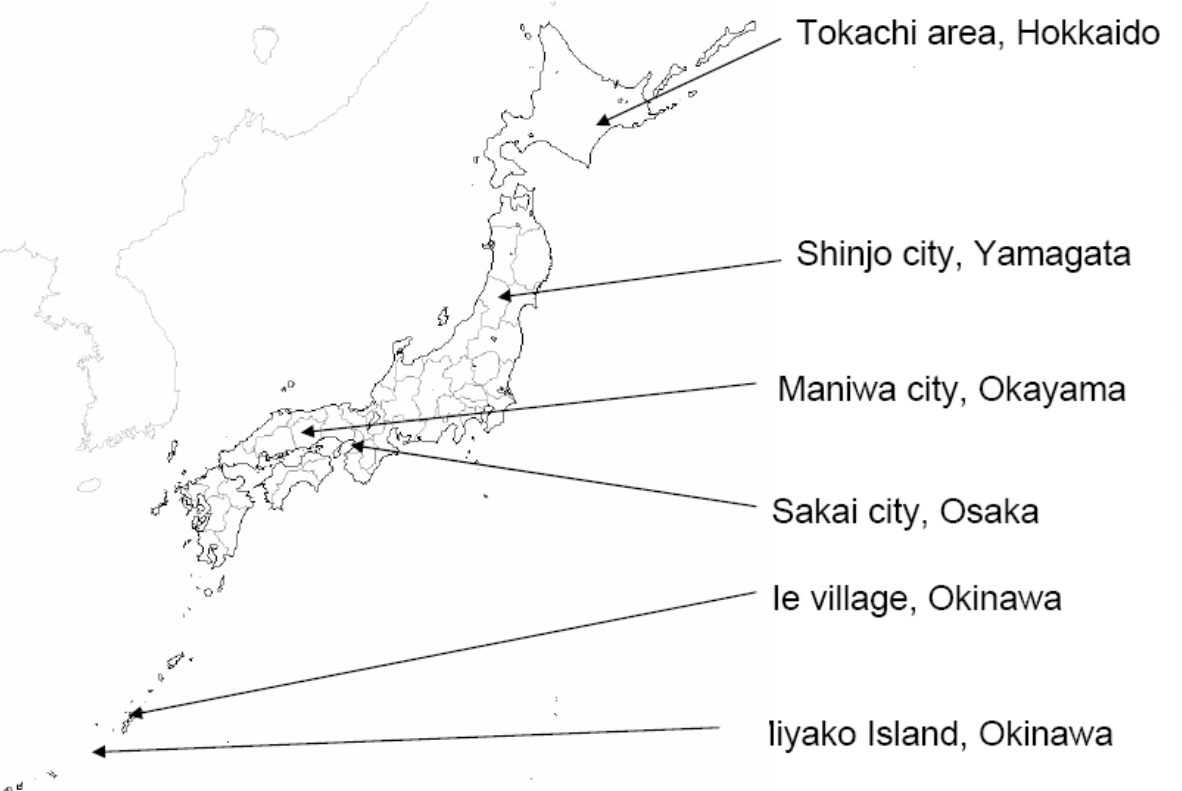

Source: Koizumi and Ohga, 2007

Figure 21 Current Biorefineries in Japan

Biodiesel doesn't receive as much attention as ethanol in Japan. Current annual production from used cooking oil is estimated at nearly 3 million liters. In 2006, Nippon Oil Corporation and Toyota Motor Corporation announced development of a palm oil-based biodiesel that performs comparably to petroleum diesel. They claim to have removed the oxygen from the palm oil, which would normally cause the fuel to degrade. Nippon Oil aims to develop a commercially viable biodiesel by 2010 (USDA). 


\section{Economics.}

\begin{tabular}{|l|l|}
\hline Ethanol & US\$/liter \\
\hline From sugarcane molasses & 1.20 \\
\hline From wheat & 1.26 \\
\hline
\end{tabular}

\begin{tabular}{|l|l|}
\hline Biodiesel & US\$/liter \\
\hline From rapeseed & 2.9 \\
\hline
\end{tabular}

Source: Koizumi and Ohga, 2007

Biofuels in use. Japan began testing E3 and ETBE in 2007.

Infrastructure and Vehicles. Japan started to offer E3 at two gasoline stations, one in Sakai City and the other in Daito City, in October 2007. E3 is also offered in Osaka but is limited to about 100 cars registered in advance with the local government. The number of E3 supplying gas stations will be increased gradually and will begin selling the product to the general public in 2008. There are about 50 stations in the Tokyo metropolitan area offering ETBE blended gasoline. Their number is expected to reach 100 during 2008, increasing to 1,000 nationwide in 2009 (Asia Times, 2007).

Trade. Japan imports ethanol (mostly from Brazil and China) to supply its beverage, chemical and pharmaceutical industries. Brazil has the world's largest ethanol export potential and it is seen by Japan as its major source of the alternative fuel. Last year, the governments of Japan and Brazil set up a study group on trading in the fuel. It is expected that large amounts of fuel ethanol will be imported from Brazil in the coming years (Ohmy News International).

Policy. In 2002, the Biomass Nippon Strategy was published, which recognized the need to halt global warming, encourage recycling in Japanese society, and foster alternative energy industries. As a signer to the Kyoto Protocol, Japan has pledged to reduce $\mathrm{CO} 2$ emissions by $60 \%$ from 1990 levels by the year 2010. To reach that goal, the Japanese government plans is to replace fossil fuels with 500,000 kiloliters with ethanol for the transportation sector by 2010 . In addition, the new National Energy Strategy, compiled in 2007 by the Ministry of Economy, Trade and Industry (METI), set a goal of reducing the nation's reliance on oil for transport to $80 \%$ from the current $100 \%$ by 2030 .

A preferential tax system for gasoline blended with ethanol is expected to be introduced in 2008, when tariffs may also be lifted on imports of ETBE. Under the planned tax system, biofuels mixed with gasoline will be exempted from the gasoline tax - currently 53.8 yen (US\$0.48) per liter - in proportion to the amount of biofuels included. For example, E3 will be taxed 1.61 yen less per liter than pure gasoline. At present, there is no tax break for gasoline mixed with biofuels, regardless of the ratios involved. The government is also expected to make imports of ETBE tariff-free, removing the current 3.1\% import tax (Asia Times, 2007).

\section{Sources:}

1. Tatsuji Koizumi, Keiji Ohga, Biofuel Programs in China, Malaysia, and Japan, 2007, http://www.usda.gov/oce///forum/2007\%20Speeches/PDF\%20speeches/OhgaK.pdf

2. US Department of Agriculture, GAIN report, 2006, http://www.fas.usda.gov/gainfiles/200605/146197881.pdf 
3. New and Renewable Energy Division, Agency for Natural Resources and Energy, Ministry of Economy, Trade and Industry (METI). February 2007,

http://www.nedo.go.jp/kokusai/kouhou/190201/1-1t.pdf

4. Asia Times, Japan steps up its biofuel drive, December 2007, http://www.atimes.com/atimes/Japan/IL13Dh01.html

5. Ohmy News International, The goal of saving 500,000 kiloliters of crude oil by 2010 is not easy to reach, May 2007, http://english.ohmynews.com/index.asp 


\section{Republic of Korea}

Korea is very interested in adding biofuels to its energy matrix, driven primarily by the desire to reduce air pollution and oil dependency. Biodiesel is the primary choice given the fact that Korea consumes large amounts of diesel (twice the amount of gasoline) and it has the option of producing feedstock domestically.

Production. Biodiesel production in Korea was 50 million liters in 2006 . There are fifteen operating biodiesel plants with a total capacity of 625 million liters/year.

There is no fuel ethanol production in Korea. Only a small amount of ethanol is produced by Changhae Ethanol Co., Ltd as an experiment.

Feedstock. Nearly $70-80 \%$ of biodiesel in Korea is produced from imported soybean oil and 20 $30 \%$ from used cooking oil. Several biodiesel plants have the capability of using palm oil (USDA). Due to rising soybean and palm oil prices, biodiesel producers are considering alternative feedstock such as jatropha oil, produced in the Southeast Asia region, the Philippines and Thailand for example.

Options for producing biodiesel feedstock domestically are currently explored in Korea. It is estimated that 300,000 - 500,000 ha of coastal land could be available for winter canola with potential output of 450,000 - 750,000 tonnes of canola oil per year. Three demonstration sites in the Southern part of Korea have been selected for cultivation (KIER, 2007).

\section{Economics.}

\begin{tabular}{|l|l|}
\hline Biodiesel & US\$/liter \\
\hline From used cooking oil & 0.90 \\
\hline From rapeseed & 0.53 (with subsidy) - 1.37 \\
\hline From soybeans & 1.06 \\
\hline
\end{tabular}

Source: KEEI, November 2007

\section{Biofuels in use}

B5 and B20 are available nationwide.

Infrastructure and Vehicles. Korea has supplied B5 through all of its gas stations since July 2006. There are about 200 stations offering B20 operating for fleets only. Korea is also testing E3 and E5 stations.

Trade. Korea imports soybean oil mainly from Argentina (86\%) and the United States (14\%). The domestic soybean oil industry estimated that of the 260,000 tonnes of soy oil imported in 2006, less than $25 \%$ was used for biodiesel production. Korea may import 1 million tonnes of soybeans by September 2008, the US Department of Agriculture forecasted recently.

Policy. The government of Korea supports the development of biofuels and it aims to develop energy policy that considers both economic growth and environmental protection.

The Ministry of the Environment (MOE) began testing biodiesel and biodiesel fuel blends in early 2002. As a result of these emission tests, MOE recommended biodiesel as a renewable fuel to the Ministry of Commerce, Industry and Energy (MOCIE). MOCIE is responsible for setting standards for petroleum and petroleum substitutes and MOE is responsible for regulating 
air pollution. In late 2002, 73 gas stations in the Seoul metropolitan area and Chonbuk Province were designated as demonstration stations and began carrying B20. By January 2006, the number of stations testing B20 reached 200. In 2003, Korea began preparing official biodiesel standards and the biodiesel demonstration was extended to June 2006. The final standards, drafted in September 2004 by MOCIE, were adopted in January 2006 and are very similar to EN14214, the European biodiesel standards (USDA, 2007).

Korea plans to mandate nationwide B3 by 2012 and will extend the current tax incentives on production of biodiesel to 2010 .

\section{Sources:}

1. Korea Energy Economics Institute (KEEI), http://www.keei.re.kr

2. Bioenergy Research Center, Korea Institute of Energy Research (KIER), 2007 http://www.kier.re.kr/

3. US Department of Agriculture, GAIN Report, 2007, http://www.fas.usda.gov/gainfiles/200708/146292125.pdf 


\section{Malaysia}

The development of biofuels in Malaysia has been identified as a new source of growth for the plantation commodities industry. The concentration is on biodiesel from palm oil due to the large domestic production of this feedstock. There is an opportunity for ethanol production from the oil palm biomass (part of it left unutilized), but this technology is yet to be commercialized. Meanwhile, the economy is focused on creating a successful industry with what exists, and that is palm biodiesel. The main concern for expanding biodiesel production in Malaysia is land availability and associated sustainability and biodiversity issues.

Production. Biodiesel production in Malaysia was 120,000 tonnes in 2006. There were five operating plants as of December 2006 with a total capacity of 258,000 tonnes per year. The government has approved licenses for the establishment of eighty four biodiesel plants with a potential annual capacity of 9.26 million tonnes. However, it is expected the pace of commercialization to slow down due to rapidly rising cost of palm oil.

Feedstock. The primary feedstock for biodiesel production in Malaysia is palm oil. Until recently, Malaysia was the world's largest palm oil producer; however Indonesia surpassed Malaysia in 2007. Together, these economies produce about $90 \%$ of the world's palm oil. In Malaysia, 11 percent of the total land area (about 62 percent of the economy's agricultural land) is devoted to palm oil. The production more than doubled during the past 10-11 years, from 7.81 million tonnes in 1995 to 16.5 million tonnes in 2006. Malaysian government policy currently allows only 6.0 million tonnes of palm oil to be converted into biodiesel.

Economics. A study by Tatsuji Koizumi and Keiji Ohga indicates that the cost of producing biodiesel from crude palm oil (CPO) was roughly US\$0.54 per liter in 2006 . The raw material is about 80 percent of the total cost. Due to the increased price of palm oil in 2007 the production cost of biodiesel from palm oil in Malaysia today is probably double that in 2006.

Biofuels in use. Malaysia introduced a type of biodiesel known as Envo Diesel, which is a mixture of $95 \%$ petroleum diesel and $5 \%$ processed palm oil (RBD palm olein). Envo Diesel is different from the biodiesel blend B5 used in Europe (it used straight palm oil, not a methyl ester) and it is intended for local use. For export markets, and local use only if necessary, the industry produces biodiesel (methyl ester) from palm oil and methanol.

Infrastructure and Vehicles. A small number of government-owned vehicles currently use biodiesel, comprising mainly palm oil, but commercial sales have yet to start.

Trade. According to the Malaysian Timber Industry Board (MTIB), from August 2006 until February 2007, 52,654 tonnes of biodiesel had been exported to the United States; EU; and Japan, generating RM132 million in revenue. Malaysia may export biodiesel to European markets at the range of 300-350 thousand tonnes by 2010 .

Policy. The National Biofuel Policy was implemented in March 2006 to encourage the production of biofuels, particularly biodiesel from palm oil, for local use and for export. The Ministry formulated the Malaysian Biofuel Industry Act which will introduce a B-5 mandate, equivalent to a biodiesel demand of 500,000 tonnes, from 2008. However, the implementation of the Act has been delayed due to soaring palm oil prices. The government will wait until prices for RBD (refined, bleached and deodorized) palm oil fall to MYR2,000 ( $\$ 1=$ MYR3.49511) per tonne or below before it decides on the exact date of the introduction of the biodiesel mandate. 


\section{Sources:}

1. Ministry of Plantation Industries \& Commodities (MPIC), http://www.kppk.gov.my/

2. US Department of Agriculture, GAIN Report 2007, http://www.fas.usda.gov/gainfiles/200704/146280889.pdf

3. Tatsuji Koizumi, Keiji Ohga, Biofuels Polices in Asia: Trade effects on World Agricultural and Biofuels Trade, Presentation at the 2007 Agricultural Forum, Arlington, VA, March 2007, http://www.usda.gov/agency/oce/forum/2007\%20Speeches 


\section{Mexico}

Mexico sees biofuels as an opportunity to diversify its energy portfolio (more than $80 \%$ of the domestic energy supply comes from fossil fuels) and promote the development of rural communities. However, no specific policy is in place to stimulate the biofuels industry.

Production. Currently, Mexico does not produce fuel ethanol. However, ethyl alcohol has been produced for the chemical, alcoholic beverage and pharmaceutical industries for many years. There are about thirty sugarcane mills in Mexico that have attached distilleries, but very few are operating, producing 60-80 million liters per year. At full capacity and efficiency, it is estimated that total production capacity for ethanol is currently at 170 million liters per year (USDA, 2007).

Biodiesel production in Mexico is limited to few small-scale plants with a total production of approximately 13,000 tonnes per year (CEH, 2006).

Feedstock. There are various crops grown in Mexico that could be used as feedstock for ethanol production, including sorghum (grain), corn, wheat, cassava, sugarcane, and sugar beet. However, sugarcane is considered the most feasible feedstock due to the opportunity for co-locating ethanol refineries with existing sugar mills. Figure 22 illustrates proposed location for fuel ethanol plants and sugarcane producing areas.

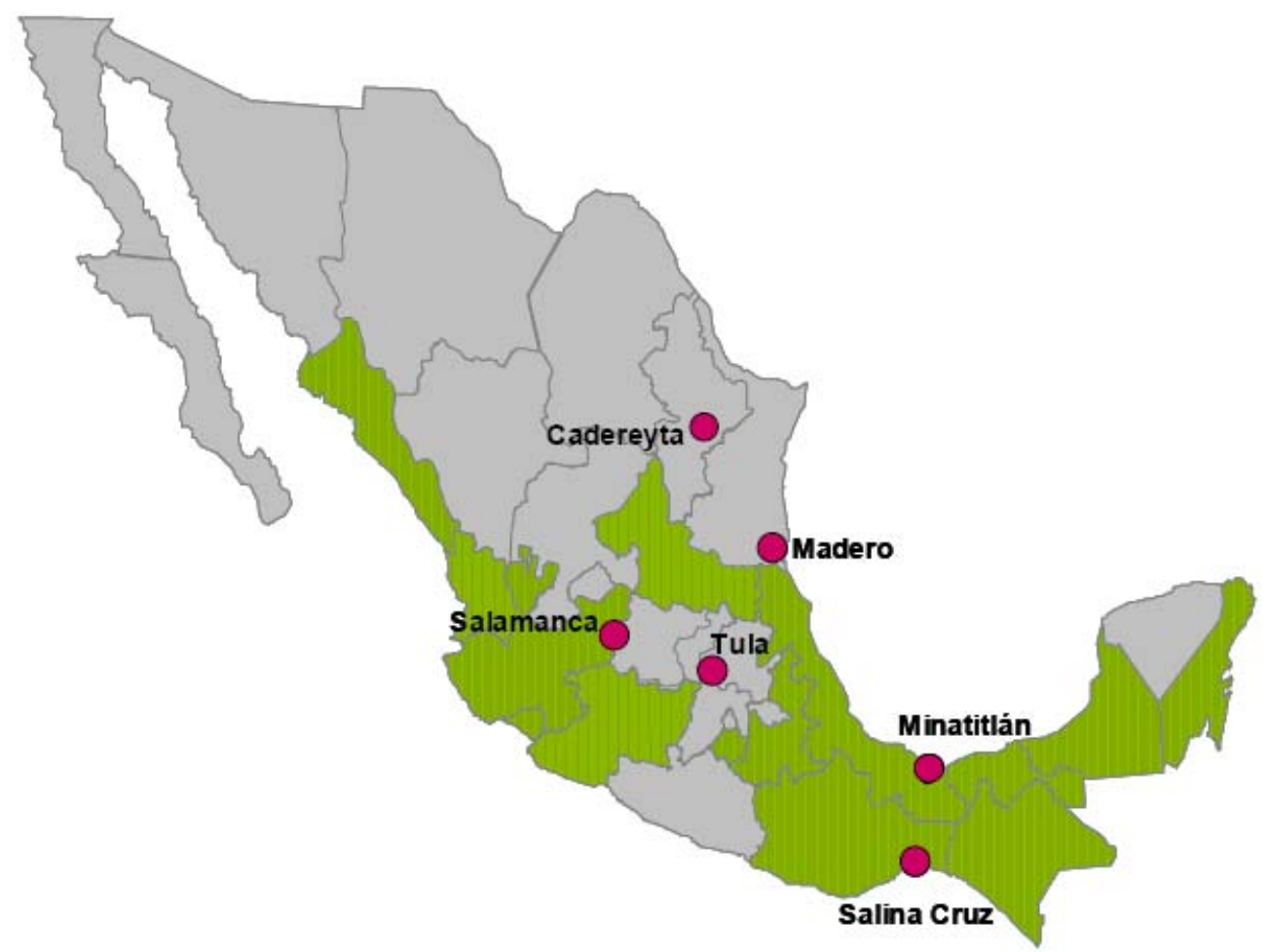

Source: SENER, 2007

Figure 22 Proposed Fuel Ethanol Refineries and Sugarcane Producing Areas in Mexico 
Sugarcane and sugar beets would need less than 1 million ha to reach the production required to displace $10 \%$ of gasoline consumption. This seems to be within the possibilities today, because agriculture uses only 21.8 million ha out of the 30 million ha "available" area for cultivation (2003 statistics). Additionally, pasture land (27.7 million ha) in some regions (SouthSoutheast) could be partially used to grow these crops. Corn would also be in this range, while cassava and sorghum would require much larger areas (SENER-BID-GTZ, 2006).

Biodiesel in Mexico is produced from animal fat and used cooking oil. Other feedstock considered by the industry includes palm oil, sunflower, safflower, canola, and soybean. Figure 23 shows areas suitable for growing these crops. Mexico has also expressed interest in jatropha, but has not developed any action plan. Estimates by SENER show that there are more than 2 million ha available for palm oil production (currently 15,000 ha), and approximately 1 million ha available for jatropha cultivation.

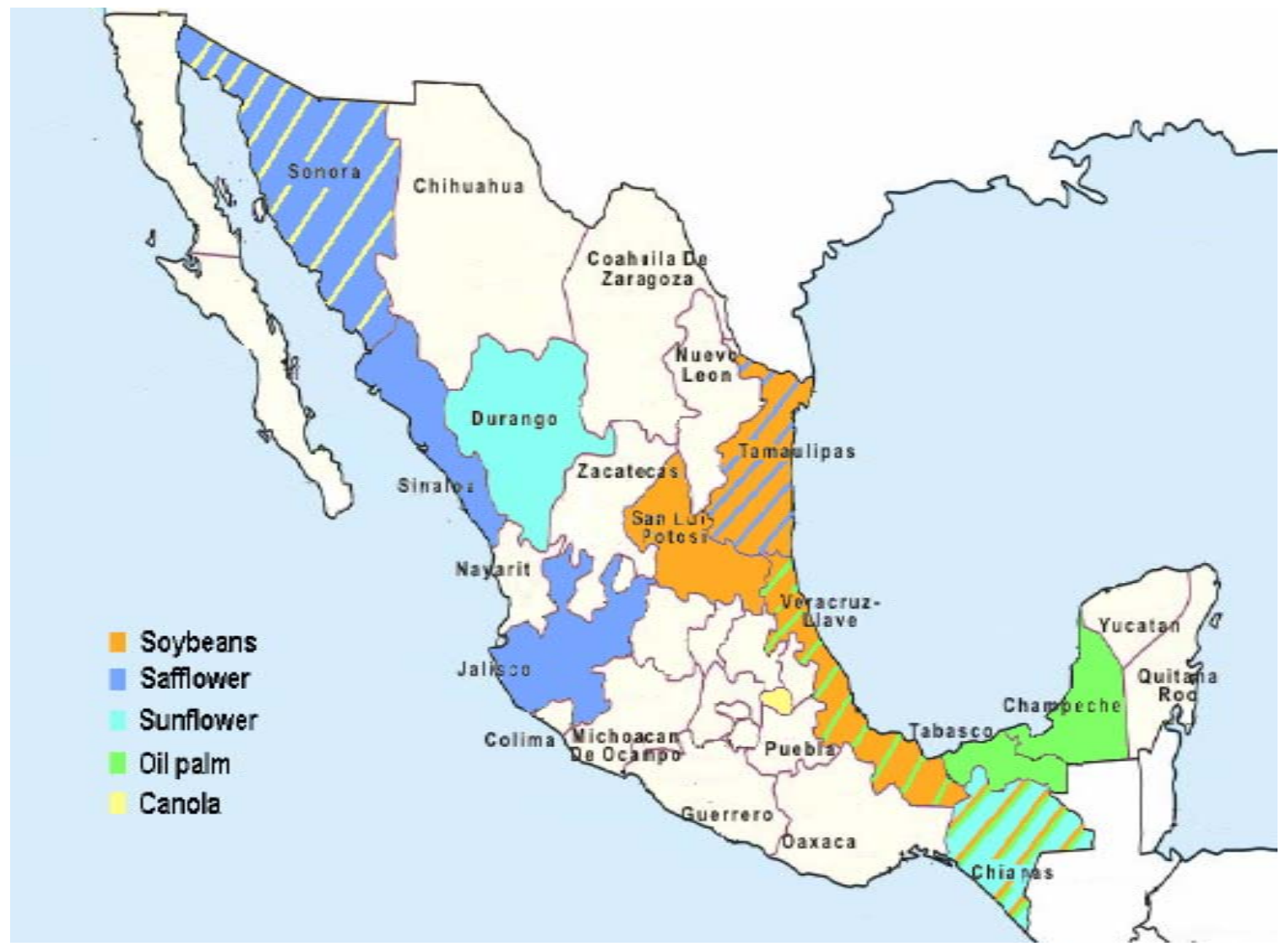

Source: SENER, 2007

Figure 23 Suitable Areas for Biodiesel Feedstock Production

\section{Economics.}

\begin{tabular}{|l|l|}
\hline Ethanol & US\$/liter \\
\hline From sorghum & 0.15 \\
\hline From corn/wheat & 0.17 \\
\hline From sugarcane/sugar beet & 0.20 \\
\hline From cassava & 0.25 \\
\hline
\end{tabular}

Source: Potenciales y Viabilidad del Uso de Bioetanol y Biodiesel para el Transporte en México, SENER-BID-GTZ, 2006 


\begin{tabular}{|l|l|}
\hline Biodiesel & US $\$$ /liter \\
\hline From jatropha & 0.53 \\
\hline From canola & 0.61 \\
\hline From sunflower & 0.63 \\
\hline From used cooking oil/tallow & 0.73 \\
\hline \multicolumn{2}{|l|}{ Source: Potenciales y Viabilidad del Uso de Bioetanol y Biodiesel para el Transporte en México, SENER-BID-GTZ, 2006}
\end{tabular}

\section{Biofuels in use}

Currently, biofuels are not used by the transportation sector in Mexico.

Infrastructure and Vehicles. PEMEX, the national oil company, would be the sole buyer of biofuel products, thus it would be the responsibility of PEMEX to make necessary upgrades to its own refining, storage, and distribution systems (USDA, 2007). It would cost \$77-120M to convert Mexico's existing gasoline storage and distribution terminals to allow for the blending of ethanol (F.O. Licht, 2007)

Trade. Mexico exports crude oil, but imports some gasoline and MTBE. Thus, if economically competitive, ethanol could save imports and stretch gasoline resources, and postpone the need to invest in additional refining capacity to produce gasoline for the domestic market. An alternative approach would be to produce ethanol for export, especially to USA where Mexico is favorably placed, geographically and trade wise, as a member of NAFTA (SENER-BID-GTZ, 2006).

Policy. The Biofuels Promotion and Development Law was approved by the Mexican Congress on April 26, 2007. Although the law does not contain any mandates or specific goals, it is seen as a "first step" toward developing a biofuels industry in the economy. It also had a broad support from the agricultural community. However, few months later, the bill was vetoed by the President Felipe Calderón on the grounds that it gives too much emphasis to corn and sugarcane production. According to Calderón, the law doesn't give enough attention to new technologies like algae and cellulosic biomass that could be more sustainable sources of biofuels. A new bill that includes the President's recommendations is in a development stage.

\section{Sources:}

1. Potenciales y Viabilidad del Uso de Bioetanol y Biodiesel para el Transporte en México (SENER-BID-GTZ), 2006, http://www.sener.gob.mx/webSener/res/169/Biocombustibles en Mexixo Estudio Com pleto.pdf

2. US Department of Agriculture, GAIN Report, 2007, http://www.fas.usda.gov/gainfiles/200706/146291366.pdf

3. Secretaria de Energia (SENER), September 2007

4. Biofuels Digest, http://www.biofuelsdigest.com; 1 February, 2008

5. F.O. Licht World Ethanol and Biofuels Report, 8 August, 2007

6. Chemical Economics Handbook (CEH) Marketing Research Report - Biodiesel, SRI Consulting, November 2006 


\section{New Zealand}

Beginning in July 2008, New Zealand's fuel companies are expected to start offering biofuels as part of the Government's plan to tackle climate change and reduce dependence on fossil fuels. According to the Biofuels Bill announced in February 2007, biofuels will have to account for $0.53 \%$ of total fuels sold in New Zealand in 2008 and increase to $3.4 \%$ by the year 2012 . Considering that the biofuels industry in New Zealand is in its very first stage of development, oil companies will likely initially satisfy their sales obligations with imported biofuels.

In response to the growing biofuels demand in New Zealand and to address the challenges facing the industry, seven prospect producers formed the Biofuels Manufacturers Association (NZBMA). Initial members of the group are Argent Energy New Zealand, Biodiesel New Zealand, Biodiesel Oils NZ, Ecodiesel, Biodiesel Australasia, Flo-Dry Engineering and Aquaflow Bionomic. In an interview with the media in March 2008, a NZBMA's spokesman pointed out three main concerns facing the biofuels industry in New Zealand: import of cheap biofuels from the United States, lack of biofuels standards, and the proposed fuel duty differential between ethanol and biodiesel. The Association believes that with ethanol not subject to fuel duty and biodiesel taxed through the road user charge, oil companies would be encouraged to import sugar cane ethanol from Brazil for economic advantage at taxpayers' expense (The New Zealand Herald, 2008).

New Zealand lacks the large-scale grain industries that are providing raw materials in other parts of the world. Thus, ethanol production relies on whey, a byproduct of the dairy industry, or second generation technology as it becomes commercially available. There is one ethanol plant in New Zealand, operated by the leading dairy producer Fonterra, using whey as feedstock. Fonterra's Edgecumbe plant produces 30,000 liters of ethanol a day and over 5 million liters in a dairy season. Fonterra also produces ethanol at other plants, including Reporoa and Tirau, for use by the alcohol beverage, chemical and pharmaceutical industries (Biopact, 2007).

There are three biodiesel production plants in New Zealand. Two, BioDiesel Oils NZ Ltd and Ecodiesel Limited, are using tallow (a by-product of the meat industry) as feedstock and have an annual capacity of 60 million liters and 20 million liters respectively. Both companies are expecting to expand in the next few years, and few others have announced their plans for building biodiesel facilities using tallow. New Zealand produces 130,000 tonnes of tallow annually surplus to its domestic requirements, which translates into approximately 127 million liters of biodiesel. The third operational biodiesel plant in New Zealand ran by BioDiesel New Zealand Ltd., uses waste vegetable oil and it hopes to ultimately produce biodiesel from rapeseed oil. The company currently produces about 1 million liters of biodiesel, and it has plantings of 1,200 hectares of canola, which it hopes to expand to at least 5,000 to 6,000 hectares (USDA). Aquaflow Bionomic is currently testing biodiesel production from algae.

Biofuels blend was not commercially available in New Zealand until August 2007, when Gull Petroleum started offering E10 at three sites in Auckland. The company plans to expand the supply to most of its 30 stations over time. E10 (Gull Force 10) will be included in Foodtown, Countdown and Woolworth's grocery fuel discount programs.

\section{Sources:}

1. USDA, GAIN Report, 2007, http://www.fas.usda.gov/gainfiles/200702/146280233.pdf

2. The New Zealand Herald, Biofuel manufacturers fear rocky road ahead for fledgling industry, March 14, 2008, http://www.nzherald.co.nz 


\section{Papua New Guinea}

Increased interest in palm and coconut oil as biodiesel feedstock and rising prices of fossil fuels are accelerating biofuels development in Papua New Guinea (PNG). The government is working on a strategy for positioning PNG as a major biofuels producer.

PNG is one of the world's largest producers of palm oil (far behind Malaysia and Indonesia) and the government actively promotes the expansion of oil palm plantations, often to the detriment of the rain forests and local communities. The plantations now are largely under the control of large companies such as New Britain Palm Oil and Golden Agri-Resources (part of Malaysian Sinar Mas). Cargill is increasing its investment in oil palm plantations and mills in PNG as well. Annual production of palm oil is about 300,000 tonnes or $1.4 \%$ of the global CPO production (Jan Willem van Gelder, 2002). The coconut oil industry is relatively small, approximately 50,000 tonnes per year.

There is no information on biodiesel production and consumption in PNG. However, there is a widespread use of straight vegetable oil (SVO) or mixture of SVO and petro-diesel. Many local suppliers of fuel blend filtered coconut oil with diesel, including Unitech in Lae, which has been successfully testing biodiesel blends in engines as part of their mechanical engineering research (Island Business). SVO is used by private vehicle owners and government fleets. Two shipping companies based in Rabaul have been buying coconut oil from the long established Copra Products Ltd mill at Malaguna for the past couple of years and have largely replaced diesel fuel for their ships (Kokonut Pacific, 2007).

In PNG, SVO and biodiesel are the alternative fuels of choice due to feedstock availability and diesel driven market. However, PNG is also interested in experimenting with ethanol. A cassava ethanol plant is under development in Launakalana, in Central province. The developer, South Korean company Changhae Tapioka, will select varietals from a pilot growing program and 43,000 acres when the plantation development effort is complete (Biofuels Digest).

\section{Sources:}

1. Agrofuels in Asia - Fuelling poverty, conflict, deforestation and climate change", by Almut H. Ernsting. Seedling, GRAIN, July 2007, http://grain.org/seedling/?id=479

2. The palm-oil - biodiesel nexus", Seedling, GRAIN, July 2007, http://www.grain.org/seedling/?id=486

3. Island Business - Coconut oil, a serious commodity option, http://www.islandsbusiness.com, October 2007

4. Kokonut Pacific Pty Ltd., Coconut power in PNG, http://www.kokonutpacific.com.au/, October 2007

5. Jan Willem van Gelder, Australian economic links with the oil palm sector of Papua New Guinea, December 2002, http://www.biodieselkeepitgreen.org/Palm\%200il/PNG\%20oil\%20palm\%20detailed\%20s tudy.pdf

6. Biofuels Digest, February 2008, http://www.biofuelsdigest.com 


\section{Peru}

Peru is interested in adding ethanol and biodiesel to its energy matrix, driven by the desire to create jobs, attract new investments, increase exports, and mitigate climate change. Some of the challenges for the biofuels industry in Peru are lack of strong policy and incentives for promoting the sector's development as well as substantial R\&D investments.

Production. Currently, there is no fuel ethanol production in Peru. As of March 2008, there are two ethanol plants under construction, both in Sullana, Piura, each with 100 million liters/year capacity. Two more plants, also in the Northern region, are planned with a total capacity of 200 million liters/year.

There is one operating biodiesel plant in Callao, Lima. The plant is operated by Pure Biofuels Corp. with a capacity of 127 million liters/year, and it is currently under expansion. Pure Biofuels acquired Interpacific Oil SAC's biodiesel production business in 2007, Peru's largest and longest running biodiesel processor. Interpacific currently produces 27 million liters per year of biodiesel and has been producing commercial quantities since 2002. Two plants are under construction: Industrias del Espino (capacity 42.5 million liters/year) near Tocache, San Martín, and Herco (capacity 85 million liters/year) near Lurin, Lima.

Feedstock. The primary feedstock for ethanol production in Peru is sugar cane. Sugar cane production was around 7 million tonnes in 2006. Sugar mills in Peru are located along the coast and have a total milling capacity of 37,000 tonnes of cane per day. Because sugar cane in Peru is produced year round, mills do not need to be very large. Yields and cane age vary greatly from one producer to another. Yields range from 53 to 190 tonnes of cane per hectare and age from 13 to 18 month between cuts (USDA).

Main feedstock for biodiesel production is palm oil. According to the Peruvian Minister of Agriculture, Peru's current palm oil production is 48,000 tonnes per year. Production is concentrated in the provinces of Ucayali, San Martin, and Loreto. Peru still needs to import significant quantities - upwards of 475,000 tonnes per year. The economy is also considering jatropha as feedstock with several plantation trails in different locations in San Martin (Tarapoto) and Amazonas (Bagua Chica) (GTZ).

\section{Economics.}

\begin{tabular}{|l|l|}
\hline Ethanol & US\$/liter \\
\hline From sugar cane & 0.25 \\
\hline Source: Palmas e Industrias del Espino, 2008
\end{tabular}

\begin{tabular}{|l|l|}
\hline Biodiesel & US\$/liter \\
\hline From palm oil & 0.24 \\
\hline \multicolumn{2}{|l}{ Source: Palmas e Industrias del Espino, 2008}
\end{tabular}

Biofuels in use. Biofuels are not currently used in Peru. However, B2 will be offered at service stations beginning July 2009, and in January 2010 E7.8 will be offered for use.

\section{Infrastructure and Vehicles}

There are no stations offering biodiesel or ethanol blends in Peru. 10 Toyota Hi Lux are running on vegetable oil as test vehicles since January 2006 (GTZ). 
Trade. Peru plans to produce ethanol and biodiesel for domestic consumption and export. According to the current US - Peru Trade Agreement, Peru would be able to export ethanol tariff free into the United States.

Policy. The Peruvian government plans to introduce a B2 mandate in January 2009 (extending it to B5 in 2011) and E7.8 mandate in 2010. To support the development of biofuels in Peru, the government adopted Law 28054 "Ley de Promoción del Mercado de los Biocombustibles" in 2003. The main objectives of the Law is to diversify the fuel market, stimulate farming and agribusiness, promote sustainable development, and offer an alternative market in the fight against drugs.

\section{Sources:}

1. Palmas e Industrias del Espino

2. Dirección General de Hidrocarburos, Ministerio de Energía y Minas, http://www.minem.gob.pe/

3. Asociacion Peruana de Productores de Azucar y Biocombustibles, http://www.appab.org/

4. US Department of Agriculture, GAIN Report, 2006 http://www.fas.usda.gov/gainfiles/200604/146187346.pdf

5. Biopact, May 2007, http://biopact.com/2007/05/pure-biofuels-to-acquire-peruslargest.html

6. Programa Desarrollo Rural Sostenible (PDRS) and RöttgerDeutsche Gesellschaft fDeutsche füür Technische Zusammenarbeit (GTZ); www.gtz-rural.org.pe 


\section{The Philippines}

The Philippines embraced the development of biofuels few years ago with hopes to achieve future energy security, augment farmers' income, and generate rural employment. It also hopes to position itself as a leading biofuels producer in the region. The main challenge facing the industry is the availability of feedstock and processing facilities to supply the demand of the National Biofuels Program set by the government.

Production. Biofuels production in the Philippines is currently limited to biodiesel only. There were seven biodiesel production plants as of August 2007, with a total output of 257 million liters per year. This production capacity exceeds the requirement of the mandatory volumes set by the Biofuels Act, thus the biodiesel producers see it as an excellent export opportunity.

Production of fuel ethanol will commence in late 2008, in time for its mandated use in 2009. Several ethanol plants are currently under construction but their scheduled completion, inclusive of their corresponding feedstock supply-base, is uncertain (USDA).

Feedstock. Primary feedstock for biodiesel production in the Philippines is coconut oil. The Philippines is one of the largest producers of coconut oil in the world - approximately 1,400 million liters per year. Nearly 20 percent (400 million liters) of this production is used for domestic consumption while the balance of 80 percent is exported. Mindanao accounts for almost 60 percent of the economy's total coconut oil production (Embassy of the Republic of the Philippines). Potential biodiesel feedstocks in the Philippines are jatropha and palm oil. The government has announced its plan to launch massive propagation and cultivation of jathropa seeds covering around two million ha of unproductive and idle public and private lands nationwide in order to produce some 5,600 million liters of biofuel in the next 10 to 12 years (Bulatlat). There are few pilot plantations growing oil palm.

In the Philippines, sugarcane is considered a primary source for ethanol production. The government sees it as the most reliable feedstock due to its well established farming technologies and the highest yield per ha compared to other feedstock (corn, cassava, and sweet sorghum). Sugarcane production in the Philippines is expected to increase to meet the requirements of the Biofuels Act. At present, the sugar industry can only supply $79 \%$ of the needs of the $5 \%$ ethanol blend which is between 200 and 400 million litres per year. The Philippines therefore needs to expand its current 167,300 sugarcane farms covering a total area of 344,700 hectares to meet the ethanol demand. The Sugar Regulatory Administration (SRA) already identified 237,748 hectares of new sugar fields, mostly in Mindanao, that can be tapped to produce fuel ethanol (Bulatlat). Additional ethanol feedstocks considered by the government are sweet sorghum and cassava.

\section{Economics.}

N/A

Biofuels in use. B1 and E10 are available nationwide.

Infrastructure and Vehicles. B1 is available through all service stations in the Philippines and it has been successfully used by thousands of vehicles in the Philippines since 2002 . E10 is currently offered by all Seaoil stations nationwide. It is expected that in 2008 more gas stations will be offering E10 (Biofuels Philippines). 
In 2007, Ford Philippines opened a plant that manufactures flexible fuel engines in Santa Rosa, Laguna. Flexible fuel engines can run on a mix of up to $20 \%$ ethanol. Production output of the facility is estimated to reach 105,000 FFV engines in the next 5 years with some units intended for export to South Africa and other ASEAN countries. The Ford plant's opening is expected to enhance and accelerate the adoption of biofuels in the economy. (USDA).

Trade. Chemrez Inc. has exported 500,000 liters of coconut based biodiesel to Germany and to Asian markets including China, Chinese Taipei, South Korea and Malaysia. If the mandated biodiesel blend increases to $2 \%$ in the next two years, as specified in the Biofuels Act, biodiesel companies in the Philippines may concentrate on supplying the domestic market and export only excess volumes.

Policy. The Philippine Biofuels Act, implemented in January 2007, establishes the following requirements for ethanol and biodiesel:

5.1 Within two years from the affectivity of this Act, at least five percent $(5 \%)$ bioethanol shall comprise the annual total volume of gasoline fuel actually sold and distributed by each and every oil company in the country, subject to the requirement that all bioethanol blended gasoline shall contain a minimum of five percent $(5 \%)$ bioethanol fuel by volume.

5.2 Within four years from the effectivity of this Act, the National Biofuels Board (NBB) created under this Act is empowered to determine the feasibility and thereafter recommend to the Department of Energy (DOE) to mandate a minimum of ten percent $(10 \%)$ blend of bioethanol by volume into all gasoline fuel distributed and sold by each and every oil company in the country. In the event of supply shortage of locally-produced bioethanol during the four-year period, oil companies shall be allowed to import bioethanol but only to the extent of the shortage as may be determined by the NBB.

5.3 Within three months from the effectivity of this Act, a minimum of one percent (1\%) biodiesel by volume shall be blended into all diesel engine fuels sold in the country; provided that the biodiesel blend conforms to the Philippine National Standards (PNS) for biodiesel. Within two years from the effectivity of this Act, the NBB created under this Act is empowered to determine the feasibility and thereafter recommend to DOE to mandate a minimum of two percent $(2 \%)$ blend of biodiesel by volume which may be increased taking into account considerations including but not limited to domestic supply and availability of locally-sourced biodiesel component (Republic Act No. 9367).

Among the incentives designed to encourage the production and use of biofuels are an exemption of the ethanol/biodiesel portions of fuel blends and an exemption from value-added taxes for raw materials (coconut, sugarcane, jatropha, cassava, etc.). There are also favorable loan policies available from banks for biofuel investors and producers.

\section{Sources:}

1. Biofuels Philippines, January 2007, http://www.biofuels.com.ph/index.html

2. Embassy of the Republic of the Philippines, Berlin, Germany, January 2007, http://www.philippineembassy.de/bln/index.php?option=com content\&task=view\&id=266\&ltemid=74

3. Bulatlat, The Philippines alternative weekly magazine, Vol. VII, No. 3, February 2007, http://www.bulatlat.com/news/7-3/7-3-biofuels.htm

4. Dr. N. A. Orcullo, Jr., De La Salle University-Dasmariñas, Biofuels Initiatives in the Philippines, October 2007, http://www.buyusa.gov/thailand/th/philippines.pdf 
5. US Department of Agriculture, GAIN Report, 2007, http://www.fas.usda.gov/gainfiles/200706/146291288.pdf

6. Republic Act No. 9367, the Biofuels Act of 2006, http://www.senate.gov.ph/republic acts/ra\%209367.pdf 


\section{Russia}

Russia is one of the world's largest producer and exporter of fossil fuels, thus biofuels don't receive particular attention. However, commitments under the Kyoto Protocol and interest in producing biofuels for export, particularly to the EU, could provide a platform for biofuels industry development.

Although, it doesn't produce fuel ethanol, Russia has very well developed ethyl alcohol industry. There are many distilleries producing ethanol for the alcohol, chemical and pharmaceutical industries with a total capacity of 1,000 million liters. There are 2 fuel ethanol plants under construction (one in Omsk, Siberia and another one in Volgograd region) and about dozen planned. Some sources report production of fuel ethanol in Russia, however no official data exists, and thus experts concede that most production is likely in the experimental stage (USDA).

Russia is one of the world's largest producer and exporter of grains, particularly wheat, barley and corn. Therefore, feedstock availability is not a concern. However, increasing grain prices may constrain bioethanol production in Russia. If grain prices continue to increase, using grain as the source of bioethanol will not be economically feasible. On the other hand, alternative sources such as sugar beet molasses may be an option. Furthermore, Russia has ample sources of cellulosic biomass from its large wood processing industry. Experts estimate the total wood biomass available for energy production at 800 million tonnes (USDA).

There is no biodiesel production in Russia. A number of companies have recently announced plans to build biodiesel plants, with rapeseed as feedstock. National output of the oilseed has been rising steadily, from 300,000 tonnes in 2005 to an expected 550-600,000 tonnes in 2006 . The Russian Agriculture Ministry has also set targets of increasing rapeseed output to 1.5 million tonnes in 2007 and 5 million tonnes in the long term. As with the ethanol industry, biodiesel produced from the proposed biodiesel plants are also intended for export markets in the EU (IADB).

Currently, there is neither federal legislation nor incentives to encourage the production and consumption of fuel ethanol in Russia. In December 2006, a group of deputies in the Duma, the lower chamber of Russia's National Assembly, prepared draft legislation that lifts the excise taxes and eases regulation on motor fuel containing less than $10 \%$ ethyl alcohol. This was intended to make bioethanol more economically attractive for alcohol producing plants. The draft legislation was scheduled for consideration by the Duma in the fall of 2007 with no results to report yet (USDA). The government charges an excise duty of at least 26 rubles (US\$1.10) to sell 1 liter of ethanol, the same as for other types of alcohol. The tax alone is more than the cost of 1 liter of gasoline (The Moscow Times).

Prime Minister Viktor Zubkov announced that a government program to develop biofuels in Russia will start in 2008. It stipulates the construction of 30 new ethanol plants and upgrades of existing facilities. Zubkov said that Russia will eventually produce 2 million tonnes of ethanol per year if the program is successful, without specifying when the government hopes to reach this target (The Moscow Times).

\section{Sources:}

1. Russian Biofuels Association (RBA), http://www.biofuels.ru/ 
2. A Blueprint for Green Energy in the Americas, Inter-American Development Bank (IADB), 2007, http://www.iadb.org/biofuels/

3. US Department of Agriculture, Foreign Agricultural Service, GAIN Report, June 2007, http://www.fas.usda.gov/gainfiles/200706/146291296.pdf

4. The Moscow Times, March 2008, http://www.moscowtimes.ru/article/1009/42/361259.htm 


\section{Singapore}

Singapore places a great importance on the development of biofuels as part of its long term energy strategy. The economy is trying to position itself as a major processing and trading biofuels hub in Asia, as well as among the leaders in second generation biofuels production. Singapore has a well established trading market and infrastructure already in place - its shipping terminals would allow transportation of biofuels to many places around the world. It also has proximity to feedstock suppliers, (such as Malaysia and Indonesia for palm oil) and emerging high demand centers (India and China for example).

In the last few years Singapore has made a considerable progress in this direction. About five biodiesel plants are currently operating on Jurong Island, Singapore's petrochemical hub, with a total capacity exceeding 700,000 tonnes per year. Few more plants are planned to begin operation in 2008. The Economic Development Board of Singapore expects the biodiesel production output to exceed 1 million tonnes per year by 2010, and reach 3 million tonnes by 2015. Most of the existing and planned facilities use palm oil, soya oil, and small amounts of used cooking oil. Jatropha is planned to be added when sufficient supplies are available.

Nine industry players, including DaimlerChrysler and Shell Eastern Petroleum, have already started a Singapore biodiesel testing project for the evaluation of biodiesel in modern diesel powered cars. The project aims to improve the use of methyl esters from palm oil in motor fuels in Southeast Asian climates (IHT, 2007).

Biodiesel - producing companies in Singapore plan to export initially to the United States and Europe while the Asian markets are developing and mandatory blending regulations in the region take effect.

To remain competitive, the government in May committed to spending 350 million Singapore dollars, or US\$240 million, in the next five years to help make Singapore a world leader in clean energy production, including both solar power - the government's main focus - and biofuels. Singapore intends to market itself as a research and development center, a global testing ground and a site for early adoption of clean energy solutions (IHT, 2007).

\section{Sources:}

1. Mr S Iswaran, Minister of State for Trade \& Industry, speech given at the 23rd AsiaPacific Petroleum Conference in Singapore, 11 September 2007, summary provided by BiodieselNow at http://www.biodieselnow.com/forums/p/18252/135097.aspx

2. International Herald Tribune (IHT), http://www.iht.com/, 29 October, 2007 


\section{Chinese Taipei}

Chinese Taipei is promoting the development and use of biofuels to reduce $\mathrm{CO}_{2}$ emissions and imports of fossil fuels. The government supports many research projects focused on advanced biofuels production technologies, not competing with the food industry such as ethanol from cellulosic biomass and biodiesel from used cooking oil.

Production. Biodiesel production in Chinese Taipei was 3.8 million liters in 2007, a substantial increase from 2.4 million liters in 2006 . There are five operating plants with a total capacity of 42.1 million liters per year. One plant is under construction with an annual capacity of 100 million liters per year.

At present, there is no fuel ethanol production. State-owned Taiwan Sugar Corp. produces around 20-30 million liters of sugarcane-based ethanol every year, mostly for the beverage industry. Two fuel ethanol plants are planned with annual capacity of 100 million liters each.

Feedstock. The primary feedstock for biodiesel production in Chinese Taipei is used cooking oil. Additional domestic feedstock includes soybean and sunflower, and the government encourages growing these crops on fallow rice paddy fields.

Chinese Taipei is considering ethanol production from sugarcane, sweet sorghum, molasses and other biomass from agricultural wastes.

Economics
\begin{tabular}{|l|l|}
\hline Ethanol & US\$/liter \\
\hline From sugar cane & 0.62 \\
\hline
\end{tabular}

\begin{tabular}{|l|l|}
\hline Biodiesel & US\$/liter \\
\hline From used cooking oil & 1.08 \\
\hline From soybeans & 1.34 \\
\hline
\end{tabular}

Biofuels in use. E3 sales started in 2006, and biodiesel is offered at different blending levels from B1 to B20.

Infrastructure and Vehicles. Nearly 300 service stations offer B1, and E3 is supplied by 8 stations. Biodiesel is used by city buses in Kaohsiung City and Chiayi County.

Trade. Currently, the biodiesel produced in Chinese Taipei is for domestic consumption, and no import has been recorded. Biodiesel incentives could force Taiwan to import more soybeans, as biodiesel demand exceeds the supply of recycled cooking oil, the US Department of Agriculture estimated.

Small volumes of ethanol are imported annually from China; Indonesia; and Thailand for use by the food industry.

Policy. The government plans to introduce an E-3 mandate in 2011. It also plans to have B1 diesel available at all gas stations nationwide by 2008 and B2 diesel by 2010 . Some policies in place include: 
- Commodity Tax and air pollution control fee exempt

- Offer incentives to encourage motorists to switch to ethanol gasoline

- Subsidies provided for demonstration programs

\section{Sources:}

1. Industrial Technology Research Institute (ITRI), http://www.itri.org.tw/eng/index.jsp

2. U.S. Department of Agriculture, GAIN report 2007, http://www.fas.usda.gov/gainfiles/200706/146291267.pdf 


\section{Thailand}

Thailand has set up serious efforts to reduce oil imports and carbon emissions by planning to replace at least 20 percent of its vehicle fuel consumption with renewable energy sources such as ethanol and biodiesel within the next five years. Biofuels are also seen by the Government as an opportunity for rural development and export.

Production. Ethanol production in Thailand was 192.8 million liters in 2007. There are nine operating plants with a total capacity of 435 million liters per year, and nine plants are under construction (440 million liters per year). Figure 24 illustrates some of the existing, underconstruction and planned production facilities.

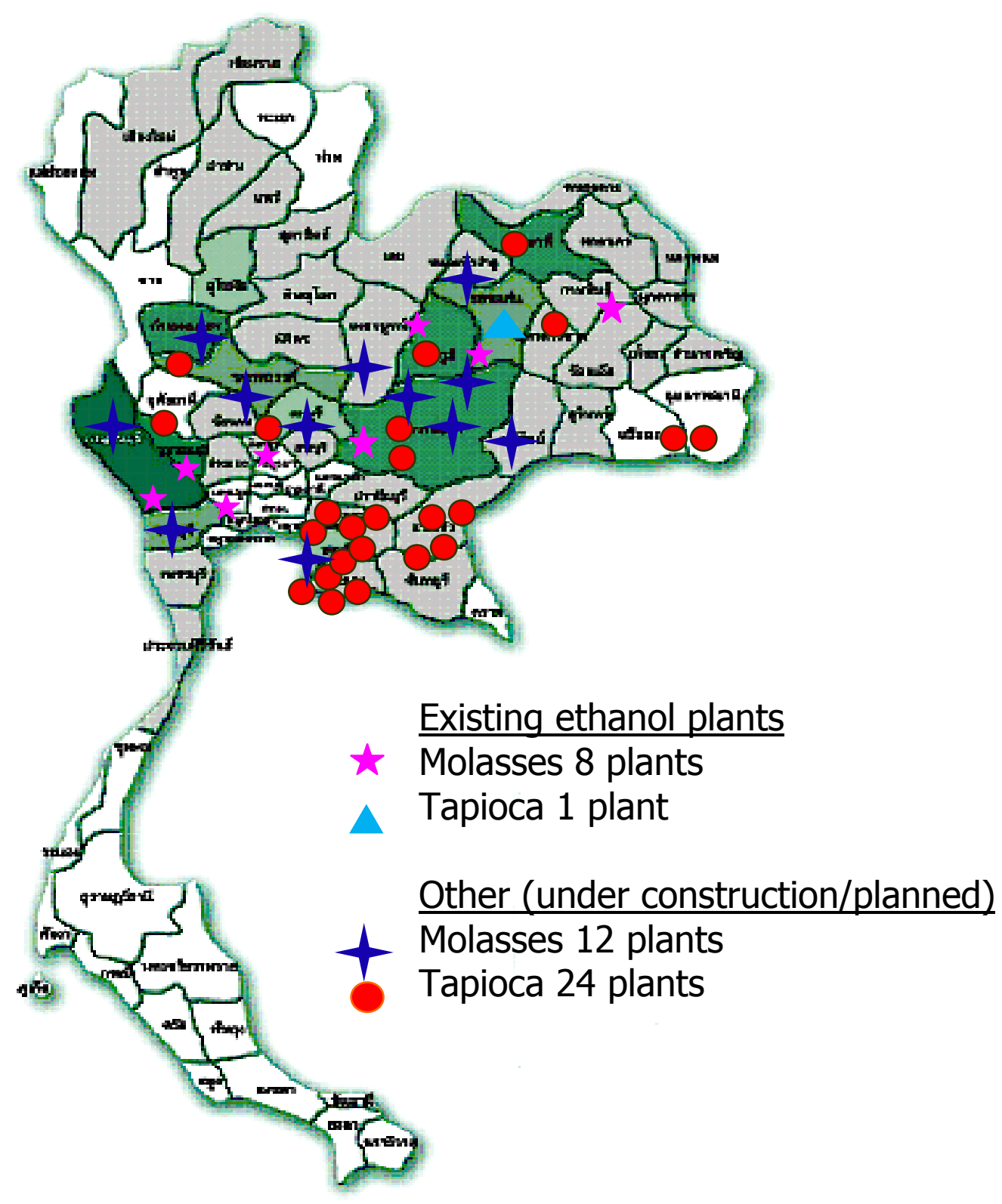

Source: DEDE

Figure 24 Ethanol Production Plants in Thailand 
Biodiesel production in Thailand was 58 million liters in 2007. Currently, there are nine biodiesel plants with a total production capacity of 655 million liters annually.

Feedstock. Almost $90 \%$ of ethanol produced in Thailand is from cane molasses. The remaining $10 \%$ is from cassava. The proportion is expected to shift over time in favor of cassava. Molasses supplies are expected to increase to 3 million tonnes, half of which will be used in food industries (mostly for liquor production), and the balance will be for exports and fuel ethanol production (USDA, 2007). Cassava production was 22.5 million tonnes in 2006 and it is expected to grow as the planned cassava-based ethanol production plants start operating.

The main raw material for biodiesel in Thailand is palm oil. The economy ranks third in the world after Indonesia and Malaysia. Total crude palm oil output is 1.3 million tonnes a year, around 800,000 tonnes of which go to the food sector. Of the 500,000 tonnes used in non-food businesses, 420,000 tonnes are now needed to make B2. At least 600,000 tonnes would be required to make B5. The Government plans to expand palm oil cultivation area by 2.5 million Rai $(1$ hectare $=6.25$ Rai) during the next five years. Few biodiesel plants are using used cooking oil as feedstock. Jatropha is seen as an alternative feedstock for biodiesel production in Thailand, and one plant intends to use this feedstock.

\section{Economics.}

\begin{tabular}{|l|l|}
\hline Ethanol & US\$/liter \\
\hline From cassava & 0.54 \\
\hline From cane molasses & 0.46 \\
\hline Source: DEDE, 2007; 34.5 Baht/US \$
\end{tabular}

\begin{tabular}{|l|l|}
\hline Biodiesel & US\$/liter \\
\hline From palm oil & 0.86 \\
\hline From used cooking oil & 0.68 \\
\hline
\end{tabular}

Source: DEDE, 2007; 34.5 Baht/US \$

Biofuels in use. Thailand currently sells gasohol (E10), which accounts for around $20 \%$ of total petroleum sales, through its service stations. The state-owned companies PTT and Bangchak started supplying E20 in January 2008. Bangchak plans to introduce E85 at its stations in the near future.

B2 is available nationwide; PTT and Bangchak started selling B5 in 2007.

Infrastructure and Vehicles. There were 3,822 gasohol service stations in Thailand as of December 2007. Currently, 40 stations in Greater Bangkok sell E20 (February 2008). B2 is available at all stations throughout Thailand; 976 stations offer B5 in Greater Bangkok.

E20 compatible vehicles are available in Thailand from Ford, Toyota, Honda and Nissan.

Trade. Most ethanol producers plan to supply ethanol domestically (particularly those who do not have sugar mill businesses) due to concerns regarding sourcing of raw materials (USDA, 2007). However, fuel ethanol export is expected to grow as the production increases in Thailand. About 14.4 million liters of fuel ethanol was exported in 2007 to Singapore; the Philippines; Chinese Taipei; Australia; and Europe. 
Policy. Policymakers in Thailand have taken measures to increase investments in the production and use of ethanol, including $\mathrm{BO}$ privilege for fuel ethanol plant, waiver on excise tax for the ethanol blended in gasohol, low rate of oil fund levy, and expansion of cassava production. Also, the government set gasohol prices around $2.0-2.50$ baht/liters cheaper than regular and premium gasoline. The government requires all its fleets to be fueled with gasohol.

The cabinet approved an excise tax reduction for car using gasoline containing at least $20 \%$ of fuel ethanol, proposed by the excise department and effective from January 1, 2008. The excise tax cut is expected to lower the price of cars by at least THB10,000 ( $\$ 1=$ THB0.03204). A car with a cylinder capacity of no more than $2,000 \mathrm{~cm}^{3}$ and an engine performance no more than $220 \mathrm{hp}$ will be taxed at $25 \%$, down from a previous $30 \%$. Cars with a cylinder capacity of no more than $2,500 \mathrm{~cm}^{3}$ and no more than $220 \mathrm{hp}$ will be charged at $30 \%$, down from $35 \%$. Finally, cars with a cylinder capacity between 2,500 and $3,000 \mathrm{~cm}^{3}$ and no more than $220 \mathrm{hp}$ will be taxed at $35 \%$, down from a previous $40 \%$. The rates apply to passenger cars and vans with fewer than 10 seats. The excise department estimates that about 30,000 new vehicles powered by E20 or higher will be in the market in 2008 (DEDE, 2008).

The Thai government announced the Strategic Plan on Biodiesel Promotion and Development in January 2005. The plan targets to replace $10 \%$ of diesel consumption in 2012 by increasing palm oil cultivation, promote community-based and commercial biodiesel production. The Thai government introduced a B2 mandate in February 2008, which would require the production of approximately 420,000 tonnes of biodiesel per year. The government is making available 3,000 million Baht in soft loans to farmers growing palm crops. It also supports R\&D of other crops such as jatropha. A B-5 mandate is planned to be introduced in 2011, and B10 in 2012.

\section{Sources:}

1. Department of Alternative Energy Development and Efficiency (DEDE), http://www.dede.go.th/

2. U.S. Department of Agriculture, GAIN Report, 2007, http://www.fas.usda.gov/gainfiles/200706/146291285.pdf

3. Energy Current, March 2008, http://www.energycurrent.com/index.php?id=3\&storyid=8770

4. Bangkok Post (Thailand), March $8^{\text {th }}, 2008$; http://www.bangkokpost.com 


\section{United States of America}

Biofuels in the United States provide a significant economic stimulus in the rural areas. Various factors contribute to the industry growth including concerns about MTBE contamination, Renewable Fuels Standard and other Federal and State policies, sustained high oil and gas prices, and a need to diversify the fuel supply with domestic, cleaner products.

Production. Annual US ethanol production increased from insignificant quantities in the 1970s to approximately 21,000 million liters in 2006. Most of the ongoing and projected biofuel expansion in the United States is for ethanol, but biodiesel is expanding as well, from negligible quantities in 2000 to about 750,000 tonnes in 2006.

According to the Renewable Fuels Association, there are about 135 existing ethanol biorefineries with a total capacity of 28,000 million liters per year (December 2007). Under construction or expansion are 74 plants with approximately 23,000 million liters capacity. There are six commercial cellulosic ethanol plants under construction. Four of them (BlueFire Ethanol, Inc., Broin Companies, logen Biorefinery Partners, and Abengoa Bioenergy) will employ biochemical conversion process, and two (Range Fuels and ALICO Inc.) will produce ethanol via thermo-chemical conversion process. When fully operational, the biorefineries are expected to produce more than 130 million gallons (492 million liters) of ethanol per year. A map illustrating the geographic location of these facilities is provided in Figure 25.

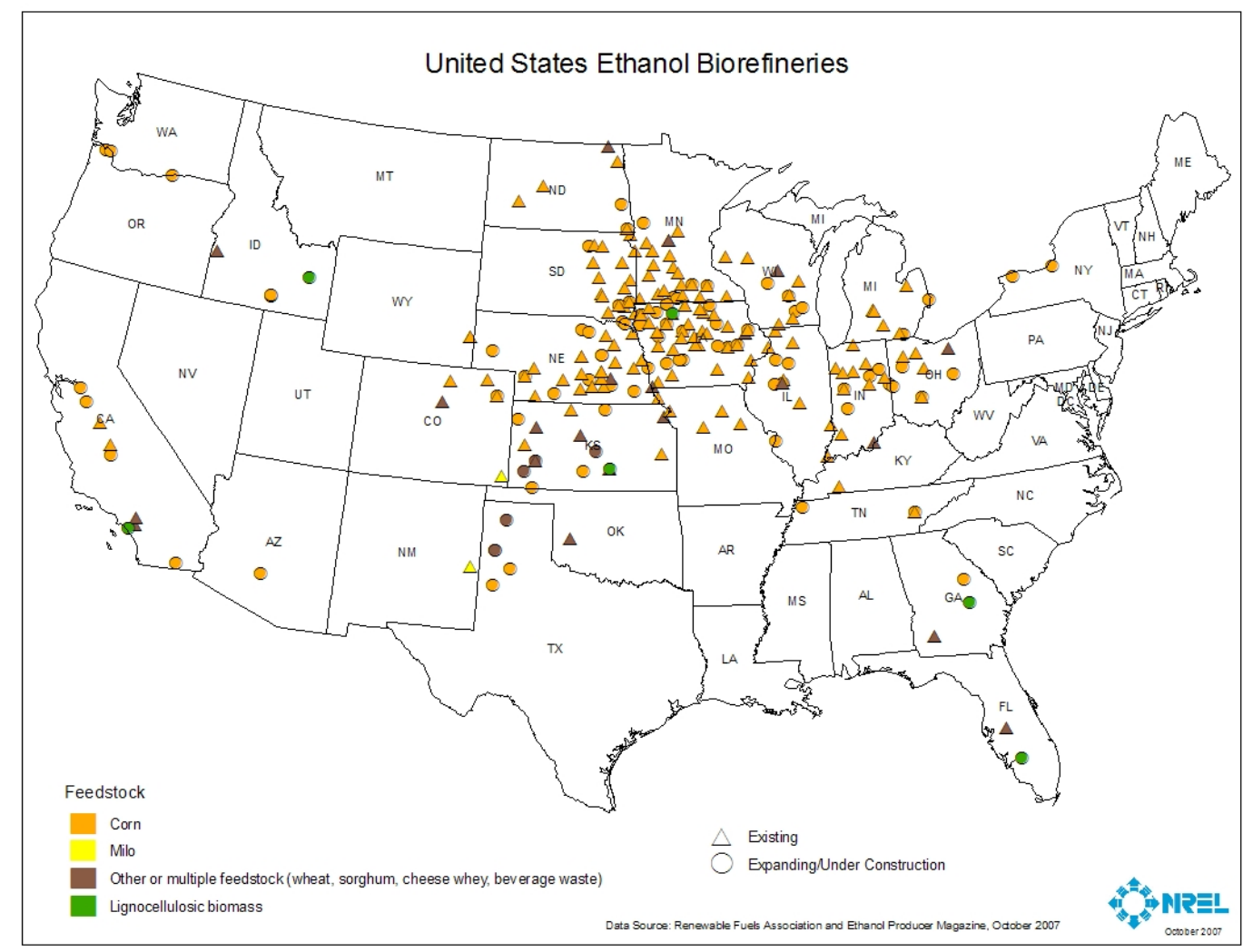

Figure 25 US Ethanol Biorefineries

According to the National Biodiesel Board, there are 165 operating biodiesel production facilities with a total capacity of 7,000 million liters (September 2007). 84 plants are under construction or 
expansion with approximately 5,000 million liters capacity. A map illustrating the existing and under construction biodiesel production facilities is provided in Figure 26.

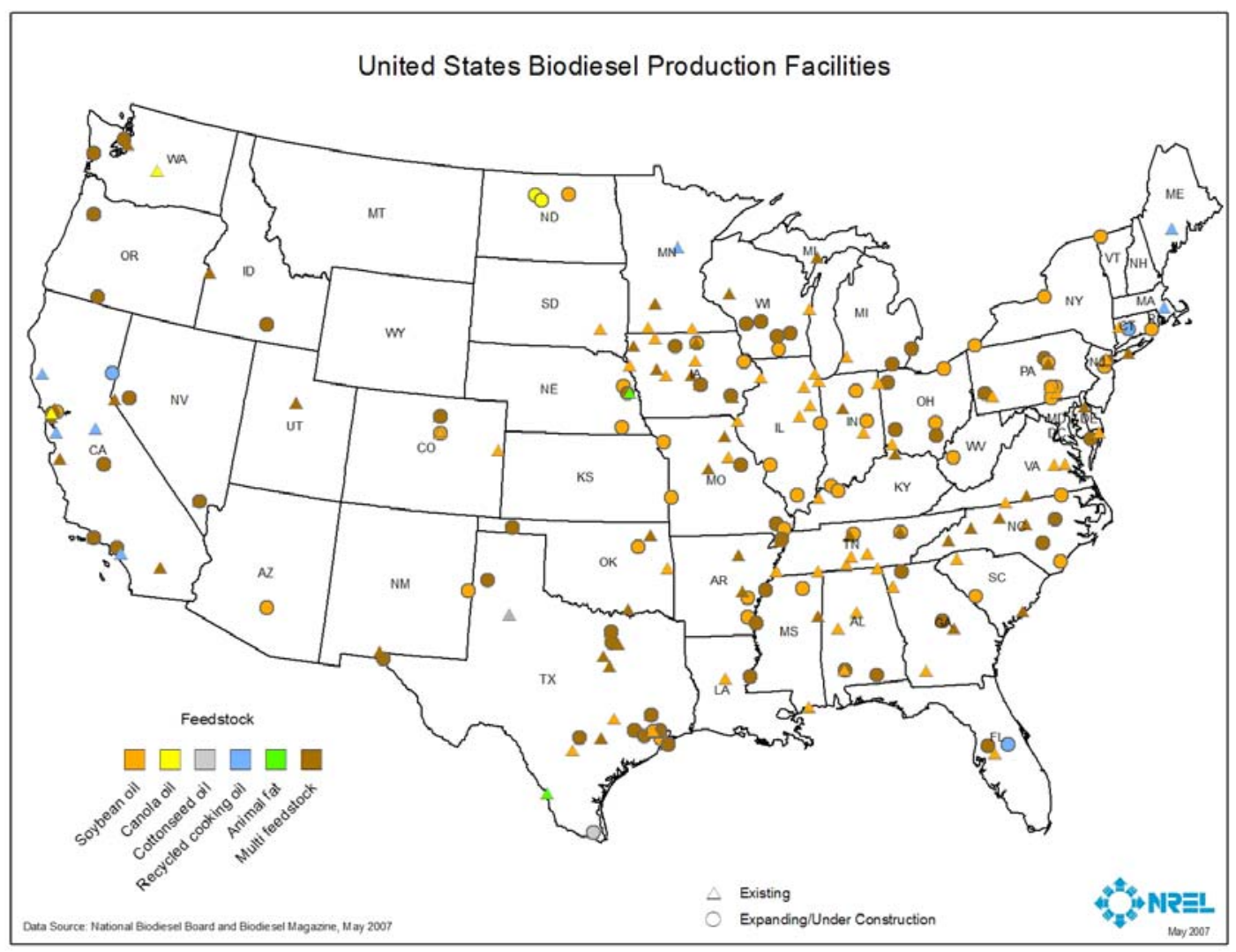

Figure 26 US Biodiesel Production Facilities

Feedstock. Today, nearly all ethanol in the US is made from corn grain. The increase in the use of corn for ethanol nearly doubles the production each year. In 2006/2007, the increase was 250 million bushels; in 2007/2008 the increase is 500 million bushels. In 2008/2009 the increase for the crop year is expected to be 1,000 million bushels. USDA predicts that by next year, the total use of corn for ethanol will approach 30 percent of the entire US crop. The rapid expansion of the corn growing sector produced an unprecedented demand shock to the world agricultural system. The price of corn is about 75 percent higher than last year, and the higher price of corn has consequently increased the price of all other grains worldwide.

Ethanol provides a rapidly growing environment for other grains, such as sorghum and milo. Ethanol production consumed approximately 26 percent of the nation's sorghum crop in 2006.

In the future, corn may cease to be the main feedstock for US ethanol production if lignocellulosic biomass (agricultural and forestry residues, dedicated energy crops) is successfully developed and commercialized as an alternative. A report by the US DOE and US Department of Agriculture (Biomass as Feedstock for a Bioenergy and Bioproducts Industry: Technical Feasibility of a Billion Ton Annual Supply, 2005) suggests that, by the middle of the 21st century, the US should be able to produce 1,300 million US tons of biomass feedstock per year, enough to displace approximately 30 percent of its current petroleum consumption. 
Approximately $90 \%$ of biodiesel produced in the US is made from soybean oil. Some experts estimate that if the biodiesel industry keeps its current momentum, over $10 \%$ of US soybean oil could be used for biodiesel production in the next few years. The US is the world leader in soybean production with about 87 million tonnes produced in 2006/2007 crop year. Half of this production was exported, which placed the economy in second place as the largest soybean exporter, after Brazil.

\section{Economics.}

\begin{tabular}{|l|l|}
\hline Ethanol & US\$/liter \\
\hline From corn & $0.46-0.48$ \\
\hline From lignocellulosic biomass & $0.53-0.66$ \\
\hline
\end{tabular}

Source: NREL, 2007

\begin{tabular}{|l|l|}
\hline Biodiesel & US\$/liter \\
\hline From soybeans & $0.39-0.79$ \\
\hline From used cooking oil & $0.26-0.50$ \\
\hline From algae & $1.50-2.00$ \\
\hline Source: NREL, 2007 &
\end{tabular}

Biofuels in use. Low-level ethanol fuel blends are sold in every state. Nearly one-third of US gasoline now contains up to $10 \%$ ethanol to boost octane or meet air quality requirements. All auto manufacturers approve the use of low-level ethanol blends because these fuels work well in gasoline engines and have no noticeable difference in vehicle performance (US DOE EERE). Ethanol is also widely available in high-level blends such as E85, used to fuel E85 - capable vehicles, such as FFVs. According to the Renewable Fuels Association, there are about 190 million liters of E85 consumed in the economy today.

The most common biodiesel blend in the US is B20, but lower level biodiesel blends, such as B2 and B5 are becoming increasingly available. Higher blends such as B100 are currently used by professional fleets. These government and private fleets are equipped with maintenance departments prepared to deal with the cold-weather performance and material concerns associated with higher blends. In comparison, B20 and lower-level blends can be used in nearly all diesel vehicles. The National Biodiesel Board estimated that about 950 million liters of biodiesel was sold in the US in 2006, much higher than the 284 million liters sold in 2005.

Infrastructure and Vehicles. As of early 2007, nearly 1,200 US fueling stations offered E85. The stations are highly concentrated in the Corn Belt, but are spreading throughout the economy. Figure 27 illustrates the geographic distribution of these stations. 


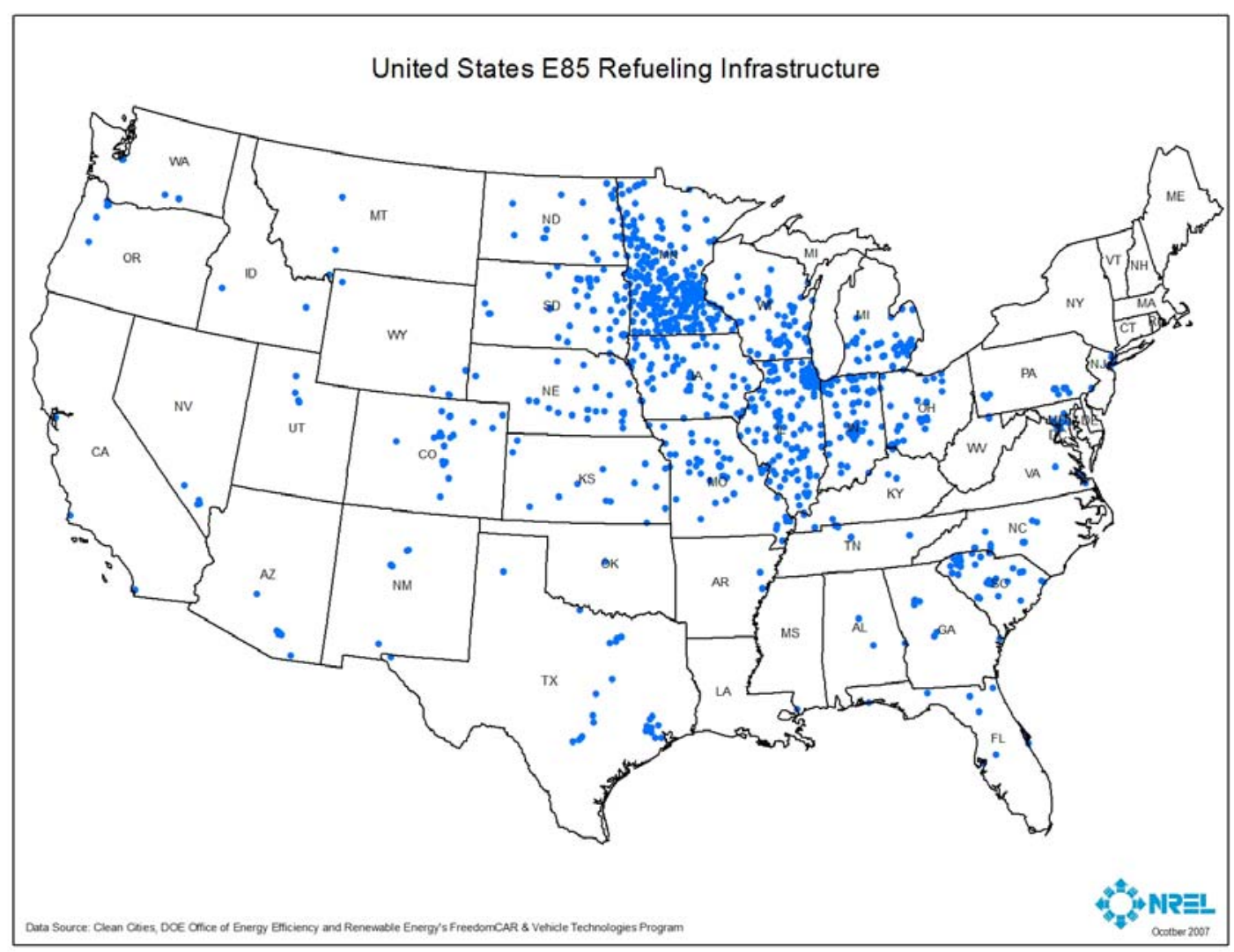

Figure 27 US E85 Refueling Infrastructure

There are about 6 million registered FFVs in the US, available in a variety of models from US and foreign automakers. More information on the FFVs available in the US is available at http://www.eere.energy.gov/afdc/vehicles/flexible fuel availability.html

Approximately 700 fueling stations offered biodiesel in 2007. The stations are available throughout the US, and Figure 28 shows their distribution. 


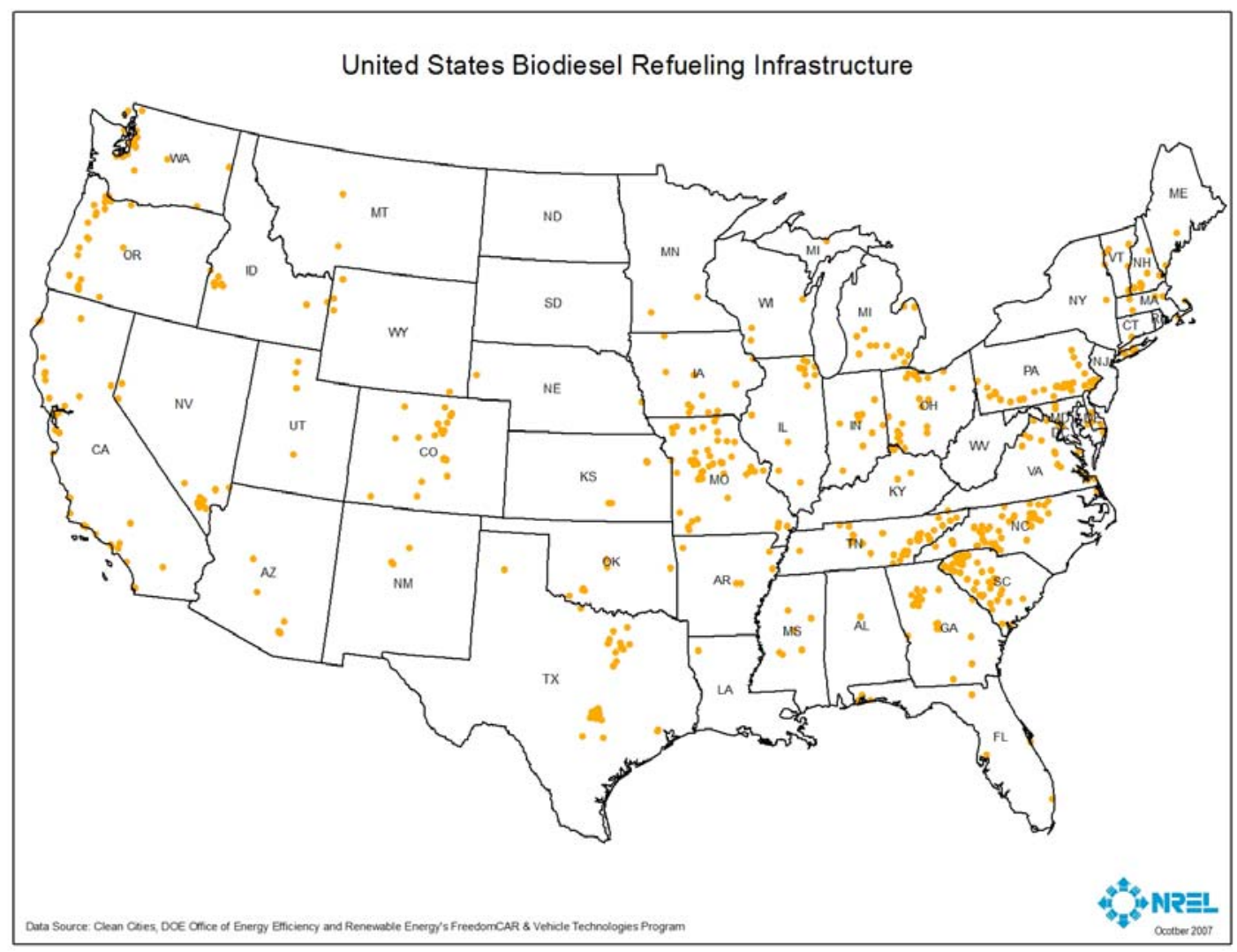

Figure 28 US Biodiesel Refueling Infrastructure

Trade. In 2006, the phase-out of MTBE in most fuel markets across the economy resulted in an unprecedented increase in ethanol demand. RFA reports that 2,500 million liters of ethanol were imported in 2006, mostly from Brazil with small volumes from Central America and the Caribbean (Jamaica; El Salvador; Costa Rica; Trinidad; and Tobago).

EarthFirst Americas Incorporated (EFA) reported twice the import of palm oil-based biodiesel from Ecuador, at the end of 2005 and early 2006. The second shipment totals 3 million liters, a substantial increase from the first shipment of 1 million liters. The announcement was received with a negative reaction by the American Soybean Association (ASA), a trade group representing US soy producers, and called on the Congress to establish protectionist measures to block imported biodiesel from competing with the domestic soy-based product.

The US biofuels import market will unlikely grow very much in the next few years given the increased domestic production. In fact, some analysts predict that the US biofuels market could become independent of imports in the next one-two years.

Policy. The US policy and legislation play a crucial role with regard to the development and use of biofuels. The National Biodiesel Board determined that the most pressing issue for the industry in 2007 was public policy. More than quality, distribution or new markets, the NBB believed policy was the issue that would most impact the vitality of the industry. 
The Energy Policy Act of $\mathbf{2 0 0 5}$ was the first major piece of federal energy legislation since 1992 and it contains a number of policies and incentives to further enhance and encourage the development and production of biofuels:

- Established a Renewable Fuel Standard (RFS) that mandates all gasoline sold in the U.S. contain 7.5 billion gallons of renewable fuels by 2012. In 2013, the renewable fuels used should contain 250 million gallons of fuel derived from cellulosic biomass

- Tax incentives for blenders of $\$ 0.51 /$ gallon (13.5 cents/liter) for ethanol, and $\$ 1.00 /$ gallon (27 cents/liter) for biodiesel

The DOE's Office of Energy Efficiency and Renewable Energy (EERE) tracks existing Federal and State biomass related policies, along with other legislation that drives the development and deployment of biofuels in the US. Additionally, the Alternative Fuels Data Center sponsored by DOE's Clean Cities Program, provides a listing of state and federal incentives and policies related to alternative fuels.

\section{Sources:}

1. Renewable Fuels Association, http://www.ethanolrfa.org/

2. National Biodiesel Board, http://www.biodiesel.org/

3. BBI International, http://www.bbibiofuels.com

4. DOE's Office of Energy Efficiency and Renewable Energy (EERE), http://www.eere.energy.gov/

5. DOE's Alternative Fuels and Advanced Vehicles Data Center (AFDC), http://www.eere.energy.gov/afdc/

6. US Department of Agriculture (USDA), http://www.usda.gov 


\section{Viet Nam}

Biofuels production in Viet Nam is in its very early stage of development. Although Viet Nam has been producing ethyl alcohol for many years (76 million liters in 2005), it has been consumed primarily by the alcoholic beverage and pharmaceutical industries. Just recently, in November 2007, the government approved the production and use of biofuels as it seeks to diversify its energy portfolio. Its target is 500 million liters of fuel ethanol and 50 million liters of biodiesel by 2020. The government plans to create favorable conditions for the development of biofuels and promote investments, including tax incentives and low-interest loans. Main priority for the biofuels R\&D in Viet Nam is increasing crop productivity and development of advanced conversion technologies.

Viet Nam is rich in biomass resources and it has great potential for biofuels production. The existing ethyl alcohol industry is already using cane molasses and starches as feedstock. Estimates show that if Viet Nam uses all cane molasses and $10 \%$ of cassava and corn production, it could produce around 320 million liters of fuel ethanol. Sugar cane production has been consistent during the past 6 years, about 15 million tonnes annually, while cassava production has grown rapidly from 2 million tonnes in 2000 to about 8 million in 2006. Viet Nam is also rich in cellulosic biomass, such as agricultural residues (rice husk, straw, baggase and cane leaf) - 45.6 million tonnes, and woody residues - 1.6 million tonnes (Tran Dinh Man, 2007). Dedicated energy crops, elephant grass in particular, are also seen as an opportunity. Pilot elephant grass plantations have been set up in Dongthap province (67 ha), BacKan (100 ha), and TuyenQuang (200 ha). Viet Nam has also expressed interest in production of ethanol from seaweeds.

Two fuel ethanol plants are expected to come online in Viet Nam during 2008 - 2009:

- Vietnam's Bien Hoa Sugar Company and Singapore's Fair Energy Asia Ltd have signed a memorandum of understanding for the construction of an ethanol plant capable of producing 63 million liters a year. The plant will be built in an industrial zone in Ninh Dien village, Chau Thanh district, in the southwestern province of Tay Ninh, and it will use sugarcane molasses (Biopact).

- Petrosetco, a subsidiary of state-run oil monopoly Petrovietnam has teamed up with Japan's Itochu Corp. to build a biorefinery in Ho Chi Minh City's Hiep Phuoc Industrial Park. The facility will use cassava as a feedstock and it is expected to produce 100 million liters of ethanol annually. The company plans to build three additional ethanol plants using cassava, sugarcane and rice as feedstock.

Potential biodiesel feedstock in Vietnam includes animal fat (catfish oil), used cooking oil, rubber seed and jatropha oil.

After two years of experimentation, the Vietnamese catfish processor and exporter Agifish announced in 2006 that it has successfully produced biodiesel using catfish oil. The company is building a 10,000 tonnes/year biodiesel facility in the southern Mekong delta province of An Giang. The company points out that a kilogram of catfish fat could produce 1 liter of biodiesel. Vietnam produced about 60,000 tonnes of "Basa" fish oil in 2005. The production in the past was primarily for exports to the United States and Europe (Mail \& Guardian).

Technology for producing biodiesel from used cooking oil has been successfully developed by HCM City's Research Centre for Petrochemical and Refinery Technology. About 73,800 tonnes of used cooking oil were produced in 2005 , which would translate to approximately 33,000 
tonnes of biodiesel. A trial project producing 2 tonnes/day biodiesel is underway by Saigon Petro (Tran Dinh Man, 2007).

Biodiesel production from rubber seed oil and other oil-bearing crops (jatropha) is under research by the Institute of Applied Materials \& Science and Institute of Tropical Biology in HCMC. The Department of Agriculture \& Rural Development has a jatropha trial plantation of 5,000 ha. Eco-Carbone has identified four regions in Vietnam for Jatropha development, and will enter into partnership with local farmers and communities for a minimum of 30,000 ha. Within the framework of the R\&D program carried out by Eco-Carbone, a series of agronomic tests for yield comparison are being implemented in order to select the most productive Jatropha species for cultivation in Vietnam. Biodiesel production is expected to start in 2010 and Eco-Carbone's objective is to reach 60,000 tons of biodiesel production per year at full capacity (Eco-Carbon).

\section{Sources:}

1. Asia Cleantech, Asia Clean Energy \& Asia Clean Technology News, November 2007, http://asiacleantech.wordpress.com/2007/11/25/vietnam-approves-plan-to-use-biofuels/

2. Tran Dinh Man, Institute of Biotechnology, VAST, Hanoi, Vietnam, Utilization of Agricultural and Wood Wastes in Vietnam, November 2007, http://biomass-asiaworkshop.jp/presentation files/34 Man.pdf

3. Biopact, August 2007, http://biopact.com/2007/08/vietnam-to-build-two-cassavaand.html

4. Eco-Carbon, March 2008, http://www.eco-carbone.com/

5. Mail \& Guardian, July 2006

http://www.mg.co.za/articlepage.aspx?area=/breaking news/breaking news internatio nal news/\&articleid=276189 


\section{Appendix B: Projected Export of Major Oilseeds and Products by 2017/18}

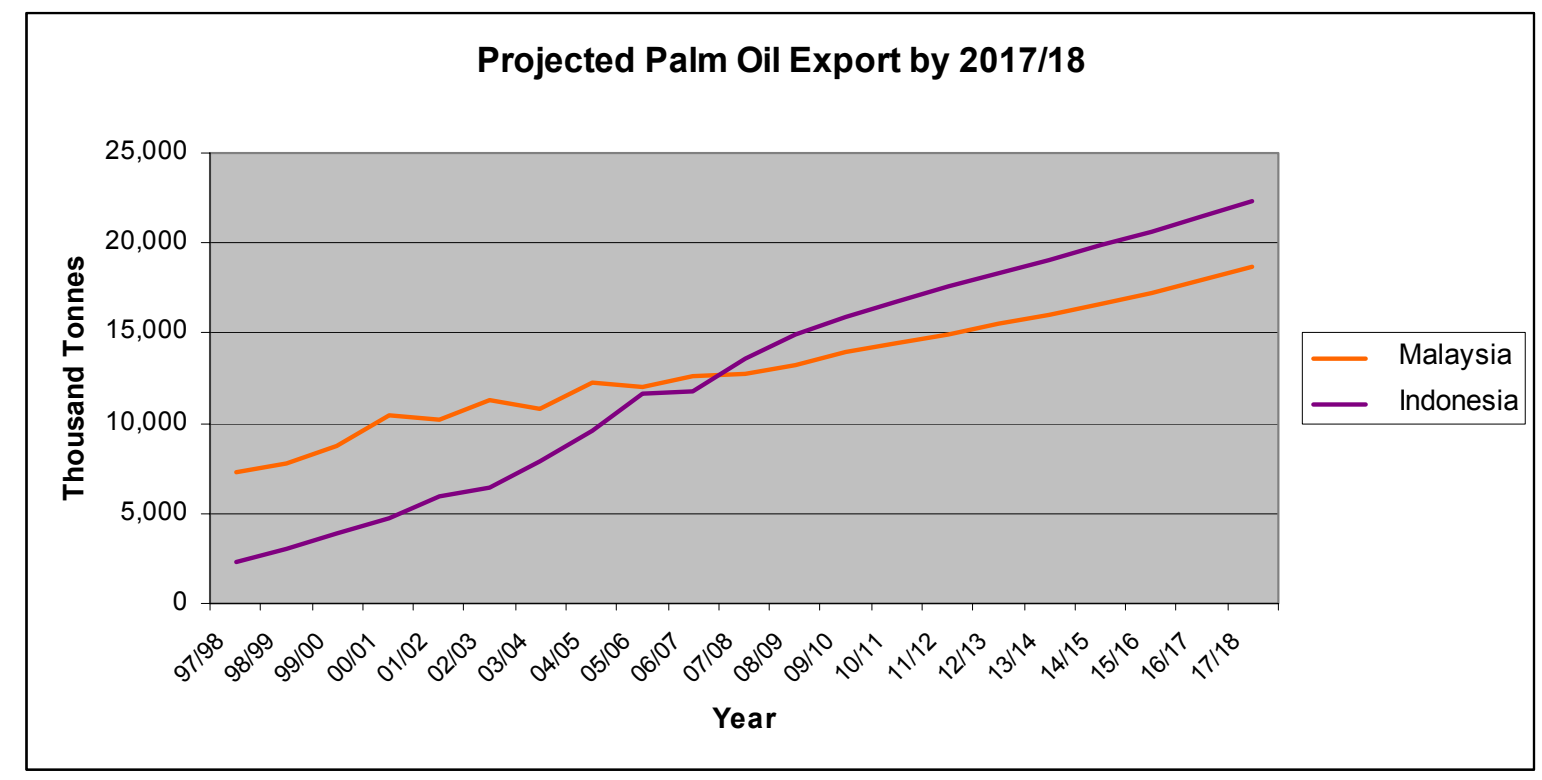

Source: World Oilseeds and Products: FAPRI 2008 Agricultural Outlook

Figure 29 Projected Palm Oil Export by 2017/18

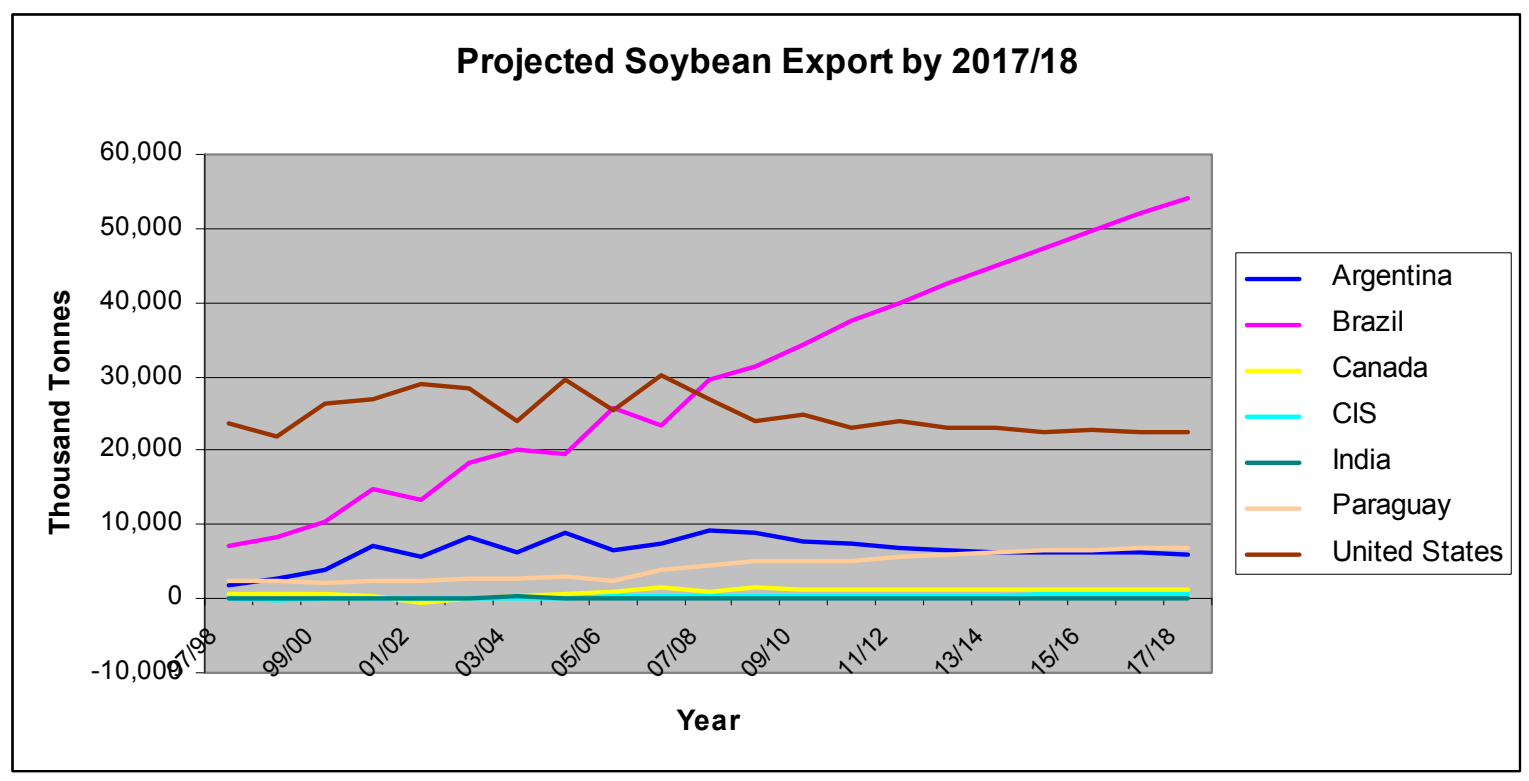

Source: World Oilseeds and Products: FAPRI 2008 Agricultural Outlook

Figure 30 Projected Soybean Export by 2017/18 


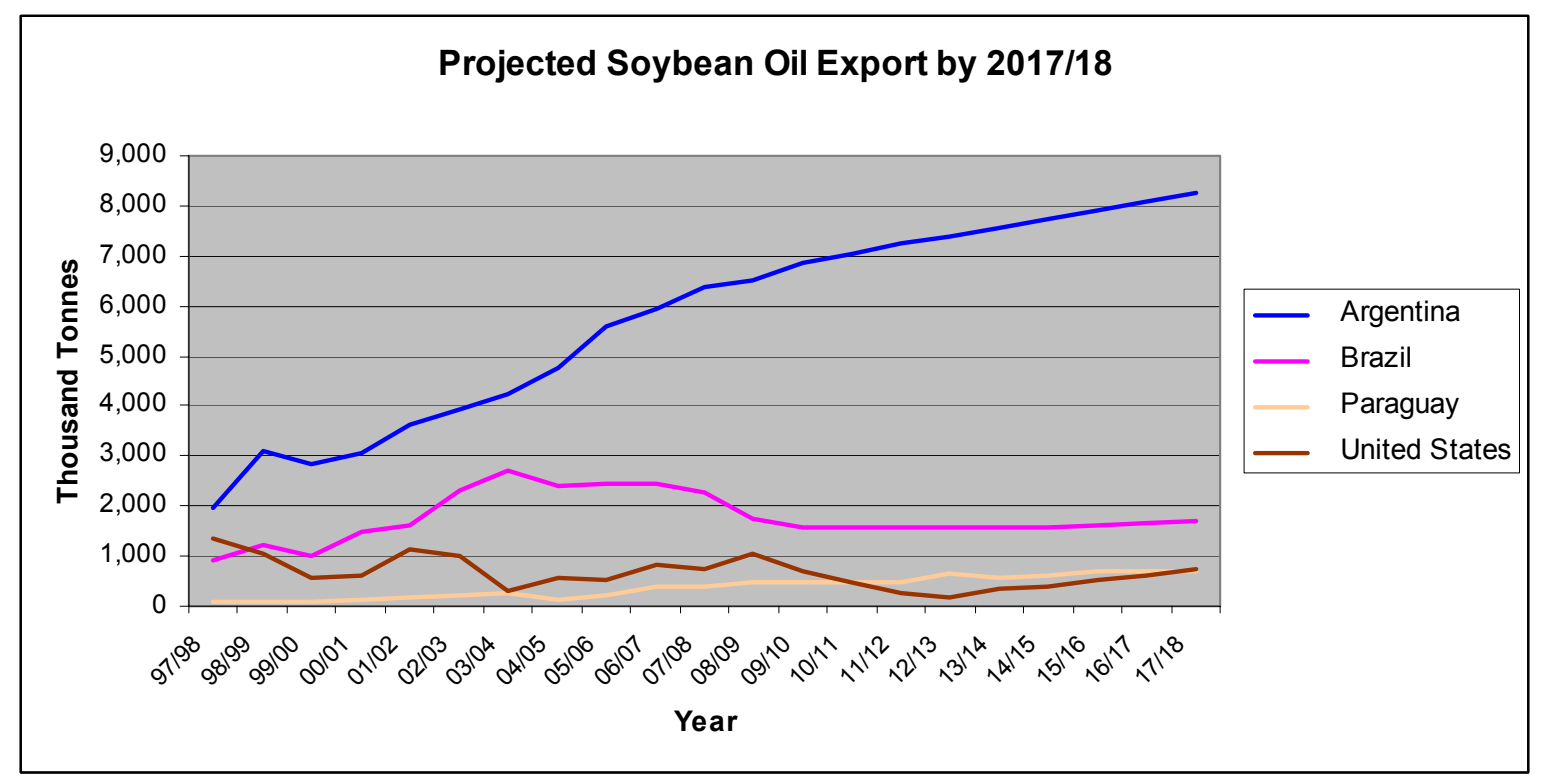

Source: World Oilseeds and Products: FAPRI 2008 Agricultural Outlook

Figure 31 Projected Soybean Oil Export by 2017/18

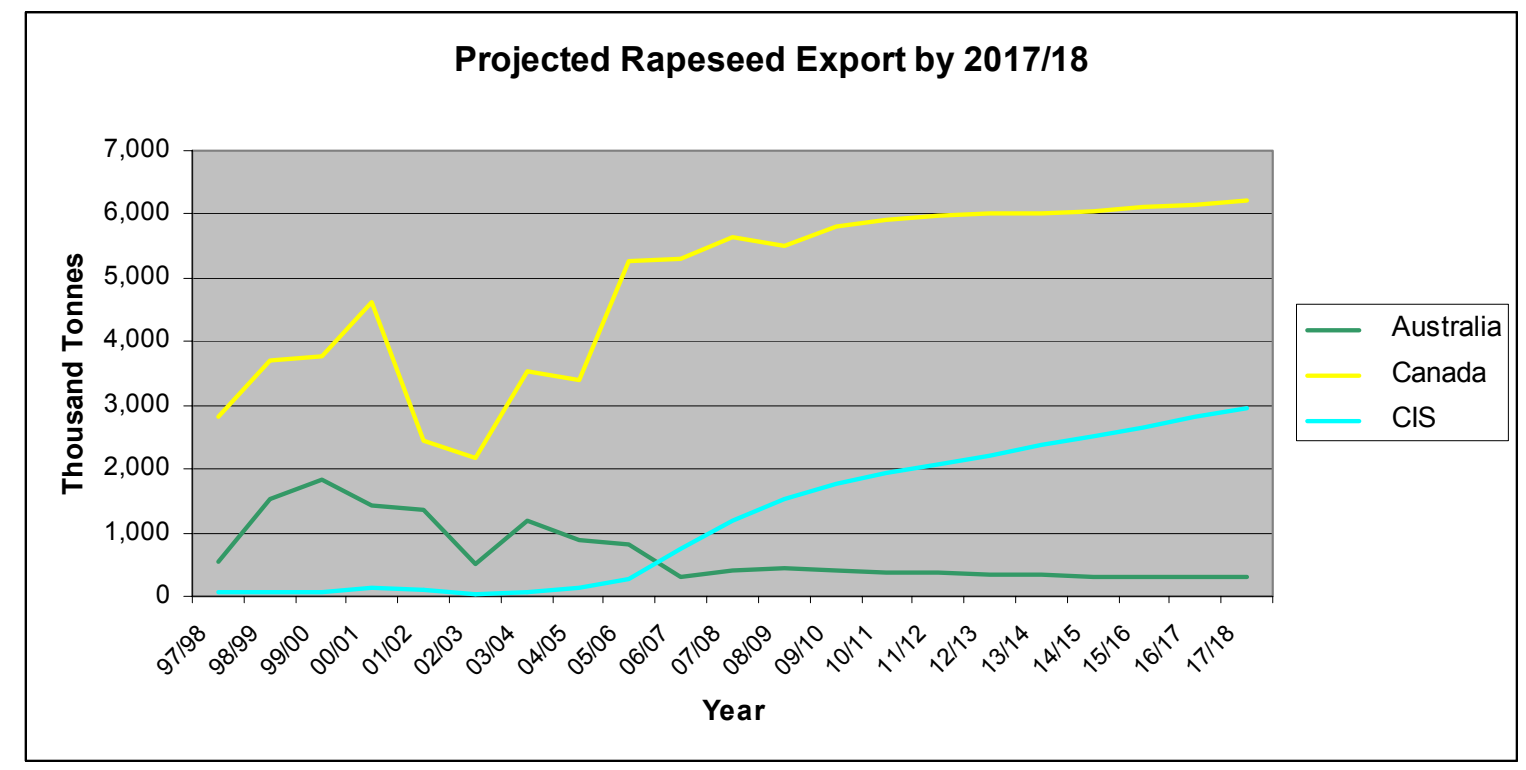

Source: World Oilseeds and Products: FAPRI 2008 Agricultural Outlook

Figure 32 Projected Rapeseed Export by 2017/18 


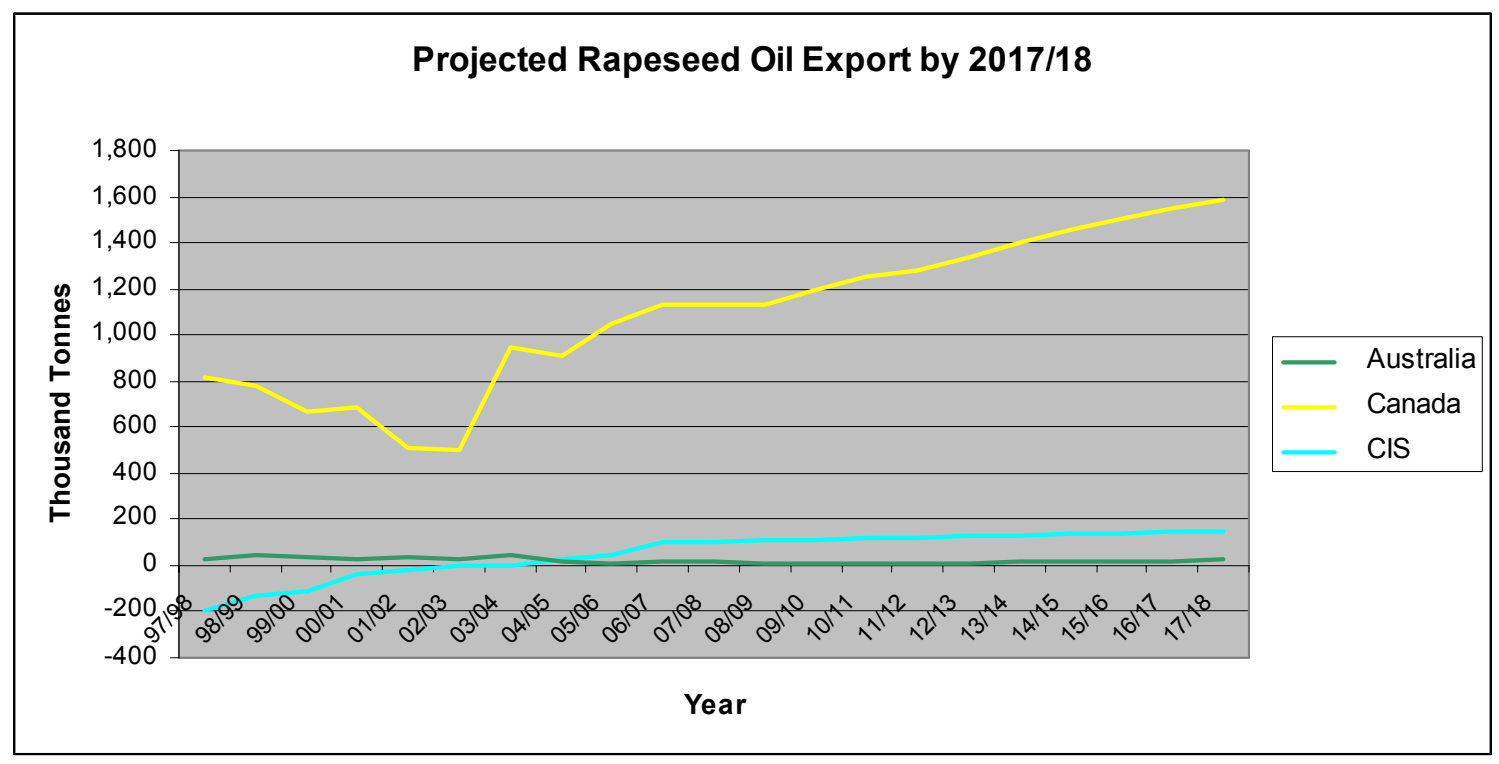

Source: World Oilseeds and Products: FAPRI 2008 Agricultural Outlook

Figure 33 Projected Rapeseed Oil Export by 2017/18

\section{Appendix C: Gasoline and Diesel Consumption in APEC Economies, 2005}

Table 10 Gasoline and Diesel Consumption in APEC Economies, 2005

\begin{tabular}{|l|r|r|}
\hline Economy & Gasoline Consumption & Diesel Consumption \\
\hline Australia & 14,520 & 7,643 \\
\hline Brunei Darussalam & 196 & 107 \\
\hline Canada & 29,751 & 12,511 \\
\hline Chile & 2,081 & 3,260 \\
\hline China & 46,097 & 46,934 \\
\hline Hong Kong, China & 325 & 1,317 \\
\hline Indonesia & 12,942 & 9,974 \\
\hline Japan & 44,391 & 27,896 \\
\hline Korea & 6,969 & 14,841 \\
\hline Malaysia & 7,756 & 4,998 \\
\hline Mexico & 27,704 & 12,487 \\
\hline New Zealand & 2,325 & 1,741 \\
\hline Papua New Guinea & $\mathrm{N} / \mathrm{A}$ & $\mathrm{N} / \mathrm{A}$ \\
\hline Peru & 771 & 2,209 \\
\hline The Philippines & 4,111 & 4,211 \\
\hline Russia & 26,260 & 13,527 \\
\hline Singapore & 727 & 1,323 \\
\hline Chinese Taipei & 7,845 & 3,657 \\
\hline Thailand & 5,280 & 12,625 \\
\hline United States & 373,930 & 135,346 \\
\hline Viet Nam & 2,546 & 3,558 \\
\hline
\end{tabular}

1,000 tonnes; Gasoline and diesel consumption by transportation sector

Source: IEA, 2005 
Prepared By:

Anelia Milbrandt

National Renewable Energy Laboratory (NREL)

1617 Cole Blvd

Golden, Colorado, USA 80401

Phone: (303) 275-3000

Website: www.nrel.gov

Dr. Ralph P. Overend

NREL Research Fellow (Retired)

Ottawa, Ontario, Canada

Produced for:

APEC Secretariat

35 Heng Mui Keng Terrace Singapore 119616

Tel: (65) 68919-600 Fax: (65) 68919-690

Email: info@apec.org Website: www.apec.org

(C) 2008 APEC Secretariat

APEC\#208-RE-01.8 